\title{
Recent Advances in Nanomaterials for Dermal and Transdermal Applications
}

\author{
Amani Zoabi, Elka Touitou * and Katherine Margulis * \\ The Institute for Drug Research, The School of Pharmacy, Faculty of Medicine, The Hebrew University of Jerusalem, \\ Jerusalem 9112192, Israel; dr.amani.zoabi@gmail.com \\ * Correspondence: to: elka.touitou@mail.huji.ac.il (E.T.); katy.margulis@mail.huji.ac.il (K.M.)
}

Citation: Zoabi, A.; Touitou, E.; Margulis, K. Recent Advances in Nanomaterials for Dermal and Transdermal Applications. Colloids Interfaces 2021, 5, 18. https:// doi.org/10.3390/colloids5010018

Academic Editor: Victor Starov

Received: 3 February 2021

Accepted: 4 March 2021

Published: 18 March 2021

Publisher's Note: MDPI stays neutral with regard to jurisdictional claims in published maps and institutional affiliations.

Copyright: (c) 2021 by the authors. Licensee MDPI, Basel, Switzerland. This article is an open access article distributed under the terms and conditions of the Creative Commons Attribution (CC BY) license (https:// creativecommons.org/licenses/by/ $4.0 /)$.

\begin{abstract}
The stratum corneum, the most superficial layer of the skin, protects the body against environmental hazards and presents a highly selective barrier for the passage of drugs and cosmetic products deeper into the skin and across the skin. Nanomaterials can effectively increase the permeation of active molecules across the stratum corneum and enable their penetration into deeper skin layers, often by interacting with the skin and creating the distinct sites with elevated local concentration, acting as reservoirs. The flux of the molecules from these reservoirs can be either limited to the underlying skin layers (for topical drug and cosmeceutical delivery) or extended across all the sublayers of the epidermis to the blood vessels of the dermis (for transdermal delivery). The type of the nanocarrier and the physicochemical nature of the active substance are among the factors that determine the final skin permeation pattern and the stability of the penetrant in the cutaneous environment. The most widely employed types of nanomaterials for dermal and transdermal applications include solid lipid nanoparticles, nanovesicular carriers, microemulsions, nanoemulsions, and polymeric nanoparticles. The recent advances in the area of nanomaterialassisted dermal and transdermal delivery are highlighted in this review.
\end{abstract}

Keywords: dermal delivery; transdermal delivery; permeation; cosmeceuticals; skin care; lipid nanocarriers; nanoemulsion; microemulsion; nanospheres; nanocapsules; transfersome; ethosome; liposome

\section{Introduction}

The skin plays a vital role in protecting the human body, functioning both as an effective permeability barrier against the penetration of exogenous molecules, pathogens, and irritants, and as a protective multilayer shield against dehydration, temperature fluctuations, ultraviolet radiation, and other environmental hazards [1-4]. This barrier function is attributed primarily to the stratum corneum (SC), the outermost layer of the epidermis, constructed of a dense network of keratin in a form of flattened corneocytes surrounded by a lipid matrix, which consists of ceramides, free fatty acids, and cholesterol [5-7]. This dense network effectively blocks molecular permeation into the deeper layers (strata) of the skin and across the skin [8].

Despite this permeability challenge, the skin is considered to be an attractive organ for local (topical, dermal) and systemic (transdermal) delivery of active substances. Being the largest organ in the human body, the skin offers a vast, painless, and accessible interface for the administration of pharmaceuticals and cosmeceuticals [9]. Topical administration of pharmaceuticals that treat skin disorders has the ability to target the disease site without a significant risk of systemic absorption and systemic side effects [9]. Topical application of cosmeceuticals allows to rejuvenate, moisturize, nourish, smoothen, and protect the skin. Transdermal delivery, in which the drug reaches the bloodstream after being absorbed through the skin, also offers several key advantages, such as avoidance of gastrointestinal side effects, escaping hepatic first-pass metabolism, and minimizing the fluctuations in plasma drug concentrations [9]. 
Various delivery routes have different requirements for the depth of active substance penetration. The transdermal route typically requires drugs to pass all sublayers of the epidermis (the $S C$ and the sublayers of the viable epidermis) to reach the microcirculation of the dermis. To achieve a local activity in the skin many active substances need to be transported at least across the SC [8]. There is a plethora of factors that can impact the effectiveness of the $S C$ barrier function. Area of application, contact time, degree of skin hydration, subject age, skin pre-treatment, physicochemical properties of the penetrant, and its concentration are among the most influential parameters that govern the spontaneous permeation through SC [10].

The majority of molecules cross the $S C$ via three main pathways $[6,11,12]$. The main pathway is the intercellular route through the lipid matrix located between the corneocytes. This pathway allows small hydrophobic molecules (typically with a molecular weight below $500 \mathrm{Da}$ ) to permeate through tight lipid junctions between the cells in a tortuous route (Figure 1a) [13,14].

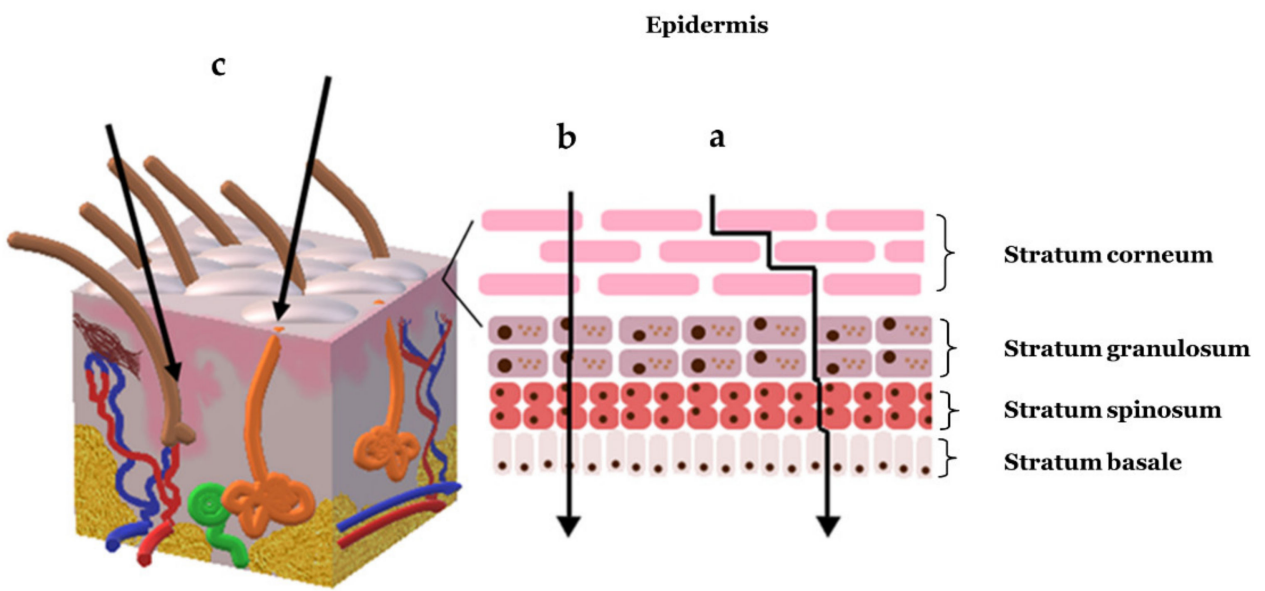

Figure 1. Skin layer structure and penetration routes: (a) intercellular (b) transcellular (c) transappendageal pathways.

Other pathways include the transcellular route, in which the penetrants pass through the corneocyte cells themselves (Figure 1b), and the transappendageal route, in which the molecules take advantage of skin appendages to penetrate (Figure 1c). The transcellular pathway enables the penetration of small hydrophilic or moderately lipophilic molecules $(\log p=1-3)$ through the keratinized corneocytes, but limits the permeability of highly lipophilic compounds. The permeation by the transappendageal pathway takes place through hair follicles, sebaceous glands and sweat ducts, which together comprise only about $0.1 \%$ of the total skin surface area (Figure 1c) but can uniquely allow the passage of atypical penetrants. Hair follicles, for example, can serve as the penetration site for large hydrophilic molecules, whose permeation through the skin is extremely challenging in general. It is noteworthy, however, that the presence of sebum, an oily material produced by the sebace ous glands, in the hair follicles may impede this permeation process [15-17].

For certain molecules, the passage by these pathways is extremely slow, which makes it challenging to attain an effective level of an active substance in the deeper skin layers or deliver substantial amounts into the bloodstream [18]. In addition, the existence of an excessive skin metabolism has been reported, and, although it is considered to be less significant than the hepatic first-pass effect, it may cause some degradation of an active substance $[19,20]$.

Therefore, a lot of effort is being invested in the development of cutaneous nanoparticulate delivery systems that can deliver active substances of a variety of molecular weights and lipophilicity into and across the skin, protect them from skin metabolism, and supply a sustained release of drugs and cosmeceuticals from the $S C$, boosting their effective concentration in deeper skin strata and in the bloodstream [18]. 
Some nanoparticular structures have a sufficient flexibility to deform and penetrate through the untreated SC along with their active cargo [21]. These particles often use either appendage or intercellular routes for penetration [21]; and a plausible explanation for the driving force behind such permeability of particles larger than skin openings is the hydration gradient-driven transport [22]. Other nanoparticular structures fail to passively penetrate on their own, but enable an efficient permeation of their active cargo at higher concentrations due to the specific interactions with the skin, for instance, the occlusive effect that is formed as a result of surface coverage [21].

The most prevalent types of nanocarriers being investigated for the cutaneous delivery of drugs and cosmeceuticals are: solid lipid nanoparticles [23-25], nanovesicular carriers [26-28], microemulsions [29,30], nanoemulsions [30], and polymeric nanoparticles [31-33]. It is noteworthy, that many of the investigated formulations comprising these nanomaterials are intended for topical treatment rather than for systemic administration through the skin. This may be owing to the fact that for the development of an effective transdermal formulation it is necessary not only to successfully transport drugs across several skin layers but also to employ an appropriate animal model for evaluation of systemic distribution, which may be challenging in some research settings. Nevertheless, several novel transdermal formulations are reported for almost every type of the aforementioned nanocarriers. The applications of these nanocarriers in topical and transdermal deliveries since 2015 are highlighted in this review.

\section{Solid Lipid Nanoparticles and Nanostructured Lipid Carriers}

Solid lipid nanoparticles (SLN) are nanometric colloidal carriers composed of solid lipid core with the entrapped active substance and stabilized by surface-active agents [34-36]. SLN were designed in the 1990s and exhibit some unique properties, such as intrinsic protection of active substance against degradation, excellent toxicity profile, high loading capacity, biodegradability, chemical versatility, scalability and the ability to undergo sterilization [23,25,36-41]. Furthermore, the interaction between the lipid core of the SLN and the waxy lipids in the SC leads to a significant permeation enhancement of the encapsulated material into the skin [42].

SLN are composed of a highly ordered solid lipid core matrix, stabilized by surfactants (Figure 2). Lipophilic active substances can be solubilized and incorporated into the lipid core, which is solid at room temperature and is liquid at hyperthermic temperatures (above $40^{\circ} \mathrm{C}$ ) [38]. This nature enables the SLN to act as an effective controlled release delivery system, which protects the encapsulated drugs from the external environment and enhances long-term stability [38,43].

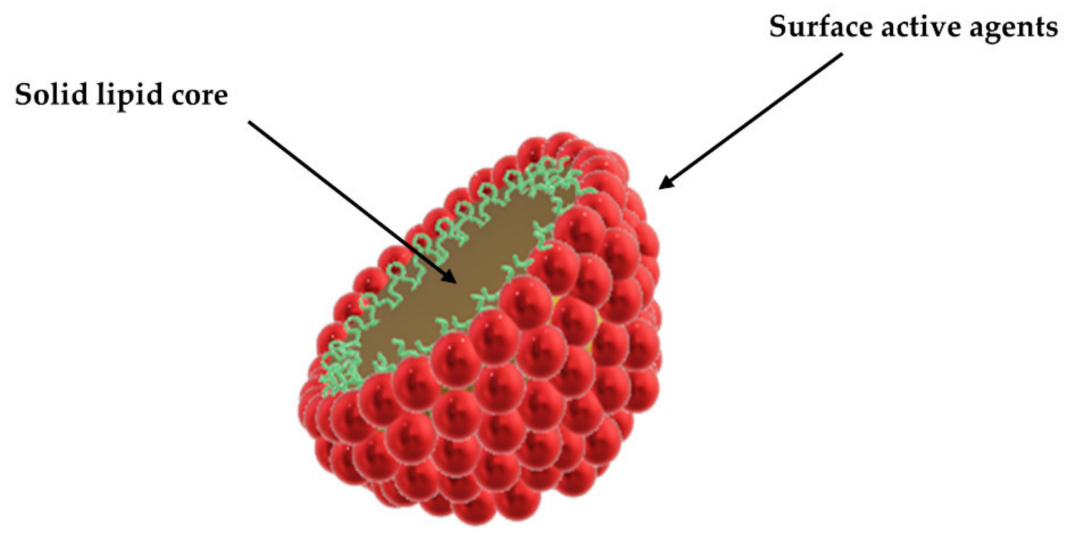

Figure 2. Solid lipid nanoparticles (SLN).

A second generation of the lipid nanoparticles called nanostructured lipid carriers (NLC), is composed of a blend of solid lipids and liquid lipids in the core in the ratio of 7:3 to 9:1 [44], which makes the lipid matrix core less ordered and decreases the melting point 
to prevent recrystallization of solid lipids (Figure 3) [36,38]. NLC are considered to be a modified version of the SLN, having the same unique properties with more versatile core composition, which leads to a higher drug loading capacity, greater stability and the ability to work at lower temperatures. Notably, the NLC are still solid at body temperature [45].

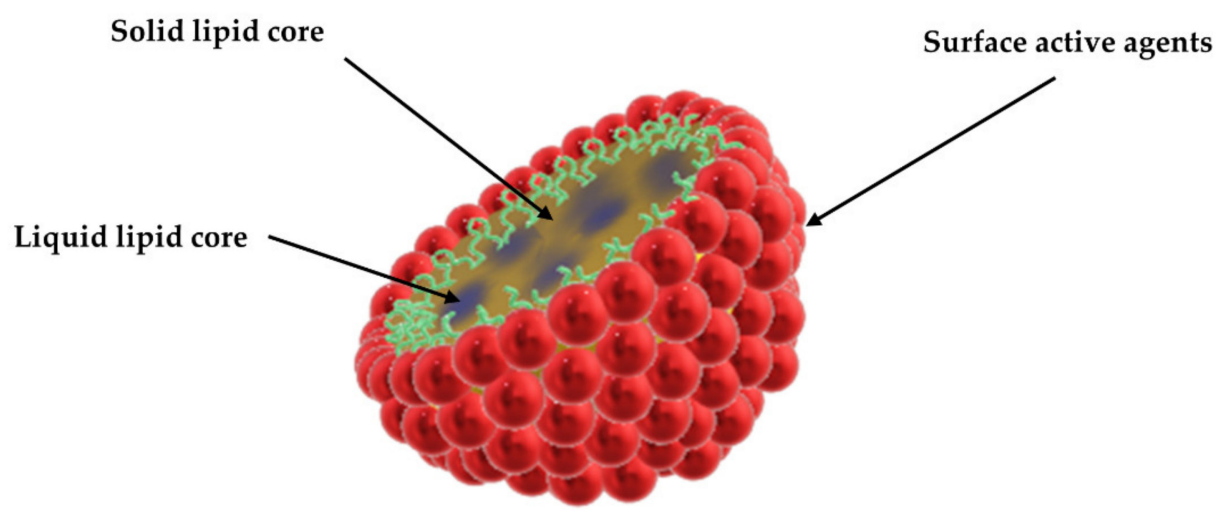

Figure 3. Nanostructured lipid carriers (NLC).

There are myriad of methods to form SLN and NLC, while the main technique used today is high-pressure homogenization. This technique is divided into a hot homogenization, in which the lipids are processed above their melting point, and to a cold homogenization, which is carried out at low temperatures and is suitable for hydrophilic and temperaturesensitive substances $[37,46]$. Other methods include sonication/ultra-sonication $[47,48]$, membrane contactor technique [39,45], phase inversion [49], solvent injection [50], emulsification [50,51], the microemulsion method [39,52], and others.

In cutaneous applications, SLN and NLC create a thin hydrophobic monolayer upon contact with the skin. This monolayer has a marked occlusive effect; it provides molecular retention, facilitates active substance penetration, and prevents water loss from the skin [53]. When topically applied, the nanoparticles interact with the sebum and skin lipids, and can alter the natural organization of the corneocytes. This interaction releases the encapsulated molecules and may enhance their penetration to deeper epidermis and dermis layers, depending on their lipophilicity $[42,54]$. Hence, SLN and NLC are extensively employed in cutaneous delivery systems. Several selected works demonstrating the most recent advances involving SLN and NLC for dermatological treatments are are detailed herein.

\subsection{Topical Delivery with SLN and NLC}

\subsubsection{Antifungal activity}

Butani et al. developed a stable SLN system containing amphotericin B for enhancing antifungal activity, with an average size of $111 \mathrm{~nm}$, negative zeta potential, and drug loading of $94 \%$ [55]. The SLN were prepared by solvent diffusion method and showed at least twice higher drug permeation and about $60 \%$ higher drug accumulation in the skin compared with the conventional gel in ex vivo hairless rat skin [55]. El-Housiny et al. formed fluconazole-containing SLN by modified hot homogenization method and ultrasonication using different concentrations of solid lipids [56]. The mean particle size was between 292 and $500 \mathrm{~nm}$, the particles were spherical and negatively charged. The SLN showed a controlled release of the drug in vitro and a significantly higher cure rate of pityriasis versicolor compared with the commercial cream Candistan ${ }^{\circledR} 1 \%$ in clinical trials [56]. Carbone et al. designed NLC containing Mediterranean essential oils and clotrimazole for the treatment of candidiasis [57]. Stable NLC were prepared by a hot homogenization method and had an average size of below $100 \mathrm{~nm}$ with a broad size distribution. In vitro studies demonstrated a prolonged release of clotrimazole, without an initial burst effect, and the enhancement of the antifungal activity of clotrimazole [57]. 


\subsubsection{Anti-inflammatory Activity}

Pivetta et al. designed thymol-loaded NLC for the local treatment of inflammatory skin diseases [58]. The NLC were prepared using a sonication method and had an average size of $108 \mathrm{~nm}$, negative zeta potential, and entrapment efficiency of $89 \%$. They were incorporated into a gel and showed anti-inflammatory activity in two different skin inflammation mouse models, and improved healing in an imiquimod-induced psoriasis mouse model [58]. Gad et al. encapsulated chamomile oil in SLN for the treatment of wounds [59]. The formulation contained stearic acid and chamomile oil (7:3 respectively) and was prepared by the hot homogenization method. Resulted nanoparticles were irregular in shape, had an average size of around $540 \mathrm{~nm}$, and were strongly negatively charged. Topical application in rats with wounds showed wound reduction, collagen deposition, and other biomarkers of wound healing acceleration [59].

\subsubsection{Antioxidant Activity}

Shrotriya et al. developed resveratrol loaded SLN for the treatment of irritant contact dermatitis, which is a chronic skin disease with severe eczematous injuries [60]. The SLN were formed by the hot ultrasonication method, had spherical shapes and an average size of below $100 \mathrm{~nm}$. The nanoparticles were negatively charged and had a resveratrol entrapment efficiency of $86-89 \%$. They were incorporated into carbopol gel and showed increased antioxidant activity compared with resveratrol-containing plain gel, and 3.5 times higher ex vivo retention of resveratrol in human skin [60]. Okonogi and Riangjanapatee prepared NLC loaded with three different concentrations of lycopene by a hot high-pressure homogenization [61]. The particles had sizes of 150-170 nm with narrow size distributions. The in vitro release study showed a fast release in the first $6 \mathrm{~h}$ with retardation in the next $18 \mathrm{~h}$ for all samples. It was found that the NLC with the highest concentration of lycopene had the slowest release rate, the most significant occlusion effect on the skin, and the highest antioxidant activity [61].

\subsubsection{Anti-acne Activity}

Kelidari et al. designed SLN of spironolactone for the treatment of acne [62]. Drugloaded SLN were prepared by a modified emulsion/solvent evaporation method followed by ultrasonication. It was found that with the increase in the ratio of surfactant to druglipid concentration, the particle size of SLN decreased and the smaller particles showed a narrower size distribution. The in vitro dissolution study showed a faster drug release from the SLN at the initial stage followed by a sustained release pattern. The ex vivo skin permeation study in rat skin revealed a significantly higher percutaneous absorption of spironolactone from SLN compared with the free drug, and a higher amount of the drug retained in the skin [62]. Ghate et al. formed NLC for the delivery of tretinoin, which has both an anti-aging and anti-acne potential [63]. The NLCs were prepared by hot melt microemulsion and hot melt probe sonication methods. The size of the NLC prepared by the microemulsion technique was greater compared to those prepared by the sonication method. Tretinoin-loaded NLC in carbopol gel showed a sustained release pattern. The in vivo skin irritation test in rats showed no irritation or erythema after the application of the gel-incorporated NLC for seven days, whereas a commercial tretinoin gel showed irritation and slight erythema within only three days of application due to a significant skin irritation effect of tretinoin [63]. Malik and Kaur, developed azelaic acid-loaded NLC, prepared by melt emulsification and ultra-sonication method [64]. These stable, spherical nanoparticles with a mean size of around $50 \mathrm{~nm}$ had high drug entrapment efficiencies $(>80 \%)$. They were incorporated into aloe-vera-based carbopol hydrogels and demonstrated a deeper skin penetration and prolonged retention abilities compared with the commercially available product (Aziderm 10\%). The NLC were well tolerated with no signs of irritation, edema, redness, or dryness. The in vivo anti-acne activity was checked in cutibacterium acnes inoculated mice ear models and showed a higher anti-inflammatory 
effect of NLC incorporated into a gel compared with the plain drug suspended in the gel [64].

\subsection{Transdermal Delivery with SLN and NLC}

Lin and Duh prepared lansoprazole-loaded NLC for transdermal delivery to treat elevated gastrointestinal acidity [65]. Drug-loaded NLC were prepared by the hot emulsification method. They contained a cationic lipid and were stabilized by an anionic surfactant. The NLC had particle sizes between 90 and $210 \mathrm{~nm}$ and were strongly negatively charged. The NLC were incorporated into hydrogels and administrated transdermally to rats. The systemic absorption and pharmacokinetics studies showed a much slower elimination rate of the drug after transdermal administration compared to the intravenous injection and revealed that lansoprazole systemic concentration remained high for $24 \mathrm{~h}$ after the transdermal administration, although the maximum drug concentration $(\mathrm{Cmax})$ and the area under the concentration-time curve (AUC) were significantly compromised in comparison with intravenous injection. It was concluded that the drug was not absorbed through the skin at once but rather accumulated in the skin and continuously penetrated into the bloodstream to maintain a constant concentration over time. There was no skin irritation observed after the transdermal application [65]. Alam et al. formed NLC loaded with an anti-hyperglycemic agent, pioglitazone, by hot homogenization followed by ultrasonication [66]. The average particle size ranged from 81 to $182 \mathrm{~nm}$, the drug loading was between $6 \%$ and $13 \%$ and the transdermal flux was between 30 and $50 \mu \mathrm{g} / \mathrm{cm}^{2} / \mathrm{h}$. The pharmacokinetics of the transdermal NLC-based formulation in vivo was compared to this of the commercial oral tablet of pioglitazone. It was found that the absorption of the drug from the transdermal formulation was much slower and lasted over an extended period of time in comparison with the oral tablet. Overall, the extent of systemic absorption of the drug from the transdermal formulation was significantly higher than that from the oral tablet, which could be attributed to the avoidance of the extensive first-pass effect. Also, the transdermal formulation demonstrated a longer antidiabetic effect compared with the commercial oral tablet [66]. Additional recent works involving SLN and NLC in dermal drug delivery are summarized in Table 1.

Table 1. Recent studies on dermal/transdermal drug delivery systems comprising NCL and SLN.

\begin{tabular}{|c|c|c|c|}
\hline Type of Lipid Nanoparticle & Drug/Active Material & Purpose & Reference \\
\hline SLN & Doxorubicin & $\begin{array}{l}\text { Development of doxorubicin-loaded cationic } \\
\text { lipid nanoparticles for cancer therapy }\end{array}$ & [67] \\
\hline SLN & Sesamol & $\begin{array}{l}\text { Formulation of solid lipid nanoparticles } \\
\text { containing sesamol for treatment of skin cancer }\end{array}$ & [68] \\
\hline SLN & Benzocaine & $\begin{array}{l}\text { Formulation of benzocaine loaded solid lipid } \\
\text { nanoparticles for local anesthetic activity }\end{array}$ & [69] \\
\hline $\mathrm{SLN}+\mathrm{NLC}$ & $\begin{array}{l}\text { Human recombinant } \\
\text { epidermal growth factor }\end{array}$ & $\begin{array}{l}\text { Development of lipid nanoparticle-based } \\
\text { dressings for topical treatment of } \\
\text { chronic wounds }\end{array}$ & [70] \\
\hline SLN & Adapalene & $\begin{array}{c}\text { Development of topical adapalene loaded solid } \\
\text { lipid nanoparticle in the gel for } \\
\text { anti-acne treatments }\end{array}$ & [71] \\
\hline SLN & Amphotericin B & $\begin{array}{l}\text { Design of topical amphotericin B solid lipid } \\
\text { nanoparticles for antifungal treatment }\end{array}$ & [55] \\
\hline SLN & Peptide LL37 and serpin A1 & $\begin{array}{l}\text { Development of nanoparticles encapsulated with } \\
\text { peptide LL37 and serpin A1 for wound healing }\end{array}$ & [72] \\
\hline SLN & Doxorubicin & $\begin{array}{l}\text { Preparing of doxorubicin-loaded solid lipid } \\
\text { nanoparticles for the treatment of skin cancer }\end{array}$ & [73] \\
\hline
\end{tabular}


Table 1. Cont.

\begin{tabular}{|c|c|c|c|}
\hline Type of Lipid Nanoparticle & Drug/Active Material & Purpose & Reference \\
\hline SLN & Paclitaxel & $\begin{array}{l}\text { Formulation of solid lipid nanoparticles } \\
\text { containing paclitaxel for the treatment of } \\
\text { skin cancer }\end{array}$ & [74] \\
\hline SLN & Flutamide & $\begin{array}{c}\text { Design of flutamide loaded solid lipid } \\
\text { nanoparticles as a potential tool for the treatment } \\
\text { of androgenic alopecia }\end{array}$ & [75] \\
\hline SLN & Triamcinolone acetonide & $\begin{array}{c}\text { Fabrication of triamcinolone acetonide loaded } \\
\text { solid lipid nanoparticles for topical treatment } \\
\text { of psoriasis }\end{array}$ & [76] \\
\hline SLN & Aceclofenac & $\begin{array}{l}\text { Preparation of aceclofenac in hydrogel-based } \\
\text { solid lipid nanoparticles for non-steroidal } \\
\text { anti-inflammatory treatments }\end{array}$ & [77] \\
\hline NLC & Tretinoin & $\begin{array}{l}\text { Formulation of nanostructured lipid carriers for } \\
\text { the topical delivery of tretinoin for anti-aging } \\
\text { and anti-acne treatments }\end{array}$ & [63] \\
\hline NLC & Peptide LL37 & $\begin{array}{l}\text { Formulation of peptide LL37 loaded } \\
\text { nanostructured lipid carriers for the topical } \\
\text { treatment of chronic wounds }\end{array}$ & [78] \\
\hline NLC & Adapalene and vitamin $C$ & $\begin{array}{l}\text { Fabrication of adapalene and vitamin } C \text { loaded } \\
\text { nanostructured lipid carriers for acne treatment }\end{array}$ & [79] \\
\hline NLC & Antimicrobial peptide nisin $\mathrm{Z}$ & $\begin{array}{l}\text { Preparation of antimicrobial peptide nisin } \mathrm{Z} \text { with } \\
\text { conventional antibiotics loaded nanostructured } \\
\text { lipid carriers to enhance antimicrobial activity }\end{array}$ & [80] \\
\hline SLN + NLC & Lidocaine and prilocaine & $\begin{array}{l}\text { Design and evaluation of lidocaine- and } \\
\text { prilocaine-coloaded nanostructured lipid carriers } \\
\text { and solid lipid nanoparticles for anesthetic } \\
\text { analgesic therapy }\end{array}$ & [81] \\
\hline SLN & Resveratrol & $\begin{array}{l}\text { Preparation of resveratrol loaded solid lipid } \\
\text { nanoparticle engrossed gel for chemically } \\
\text { induced irritant contact dermatitis }\end{array}$ & {$[60]$} \\
\hline SLN & Piperine & $\begin{array}{c}\text { Formulation of piperine loaded solid lipid } \\
\text { nanoparticles for treatment of } \\
\text { rheumatoid arthritis }\end{array}$ & [82] \\
\hline SLN + NLC & Propolis by-product & $\begin{array}{c}\text { Preparation of nanostructured lipid systems } \\
\text { containing propolis by-product for } \\
\text { wound healing }\end{array}$ & [83] \\
\hline SLN & Piroxicam & $\begin{array}{l}\text { Formulation of piroxicam loaded solid lipid } \\
\text { nanoparticle for anti-inflammatory activity }\end{array}$ & [84] \\
\hline SLN + NLC & Minoxidil & $\begin{array}{c}\text { Development of minoxidil loaded } \\
\text { nanostructured lipid carriers and solid lipid } \\
\text { nanoparticles for alopecia topical treatment }\end{array}$ & [85] \\
\hline SLN & $\begin{array}{l}\text { Resveratrol, vitamin } \mathrm{E} \text {, and } \\
\text { epigallocatechin gallate }\end{array}$ & $\begin{array}{l}\text { Development and evaluation of solid lipid } \\
\text { nanoparticles containing resveratrol, vitamin E, } \\
\text { and epigallocatechin gallate for } \\
\text { antioxidant benefits }\end{array}$ & [85] \\
\hline SLN & Silybin & $\begin{array}{c}\text { Development of silybin loaded solid lipid } \\
\text { nanoparticle enriched gel for irritant } \\
\text { contact dermatitis }\end{array}$ & [86] \\
\hline SLN & Fluconazole & $\begin{array}{l}\text { Formulation of fluconazole loaded solid lipid } \\
\text { nanoparticles topical gel for the treatment of } \\
\text { pityriasis versicolor }\end{array}$ & [56] \\
\hline
\end{tabular}


Table 1. Cont.

\begin{tabular}{|c|c|c|c|}
\hline Type of Lipid Nanoparticle & Drug/Active Material & Purpose & Reference \\
\hline SLN & Itraconazole & $\begin{array}{l}\text { Development of solid lipid nanoparticles } \\
\text { containing itraconazole with a layer of azole } \\
\text { dimethyldioctadecylammonium bromide for } \\
\text { skin cancer treatments }\end{array}$ & [87] \\
\hline NLC & Thymol & $\begin{array}{c}\text { Development of nanostructured lipid carriers for } \\
\text { topical delivery of thymol for } \\
\text { anti-inflammatory activity }\end{array}$ & [58] \\
\hline NLC & Lidocaine & $\begin{array}{c}\text { Development of lidocaine loaded nanostructured } \\
\text { lipid carriers for topical anesthesia }\end{array}$ & [88] \\
\hline NLC & Mometasone furoate & $\begin{array}{l}\text { Formulation of nanostructured lipid } \\
\text { carrier-based hydrogel of mometasone furoate } \\
\text { for the treatment of psoriasis }\end{array}$ & [89] \\
\hline SLN & Metformin & $\begin{array}{l}\text { Development of metformin loaded solid lipid } \\
\text { nanoparticles for anti-inflammatory treatments }\end{array}$ & [90] \\
\hline SLN & Ibuprofen & $\begin{array}{c}\text { Formulation of topical ibuprofen loaded solid } \\
\text { lipid nanoparticle gel for } \\
\text { anti-inflammatory treatment }\end{array}$ & [91] \\
\hline NLC & Donepezil & $\begin{array}{l}\text { Preparation of nanostructured lipid carriers } \\
\text { containing donepezil for transdermal delivery } \\
\text { for Alzheimer's disease treatment }\end{array}$ & [92] \\
\hline NLC & Voriconazole & $\begin{array}{c}\text { Development and evaluation of voriconazole } \\
\text { loaded nanostructured lipid carriers for } \\
\text { antifungal applications }\end{array}$ & [93] \\
\hline SLN & $\begin{array}{l}\text { Idebenone ester with } \\
\text { polyglutamic acid }\end{array}$ & $\begin{array}{c}\text { Formulation of solid lipid nanoparticles } \\
\text { containing idebenone ester with pyroglutamic } \\
\text { acid for antioxidant activity and enhancing } \\
\text { hydrating effects }\end{array}$ & [94] \\
\hline SLN & Chamomile oil & $\begin{array}{l}\text { Formulation of chamomile oil loaded solid lipid } \\
\text { nanoparticles to enhance wound healing }\end{array}$ & [59] \\
\hline SLN & Tazarotene & $\begin{array}{l}\text { Development and optimization of tazarotene } \\
\text { loaded solid lipid nanoparticles for the treatment } \\
\text { of psoriasis }\end{array}$ & [95] \\
\hline NLC & Rosemary essential oil & $\begin{array}{l}\text { Encapsulation of rosemary essential oil into } \\
\text { nanostructured lipid carriers for wound healing }\end{array}$ & [96] \\
\hline NLC & Clotrimazole & $\begin{array}{c}\text { Preparation of clotrimazole loaded } \\
\text { Mediterranean essential oils nanostructured } \\
\text { lipid carriers for the treatment of candida } \\
\text { skin infections }\end{array}$ & [57] \\
\hline NLC & Dithranol & $\begin{array}{l}\text { Formulation of dithranol loaded nanostructured } \\
\text { lipid carrier-based gel for the treatment } \\
\text { of psoriasis }\end{array}$ & [97] \\
\hline NLC & Peppermint essential oil & $\begin{array}{l}\text { Encapsulation of peppermint essential oil in } \\
\text { nanostructured lipid carriers for wound healing }\end{array}$ & [98] \\
\hline NLC & Triptolide & $\begin{array}{l}\text { Development of triptolide loaded } \\
\text { nanostructured lipid carriers for transdermal } \\
\text { delivery to treat rheumatoid arthritis }\end{array}$ & [99] \\
\hline SLN & (+)-Limonene 1,2-Epoxide- & $\begin{array}{l}\text { Preparation of }(+) \text {-limonene 1,2-epoxide loaded } \\
\text { solid lipid nanoparticles for anti-cancer activity }\end{array}$ & [100] \\
\hline SLN & Miconazole nitrate & $\begin{array}{l}\text { Formulation of miconazole nitrate loaded } \\
\text { lipid-based nanocarrier for antifungal activity }\end{array}$ & [101] \\
\hline
\end{tabular}


Table 1. Cont.

\begin{tabular}{|c|c|c|c|}
\hline Type of Lipid Nanoparticle & Drug/Active Material & Purpose & Reference \\
\hline SLN & Sumatriptan & $\begin{array}{c}\text { Preparation of sumatriptan loaded solid lipid } \\
\text { nanoparticles for transdermal delivery to } \\
\text { treat migraine }\end{array}$ & [102] \\
\hline SLN + NLC & Ropinirole & $\begin{array}{l}\text { Development of ropinirole loaded lipid } \\
\text { nanoparticles embedded in hydrogel for } \\
\text { Parkinson's disease treatment }\end{array}$ & [103] \\
\hline SLN + NLC & Capsaicin & $\begin{array}{c}\text { Formulation of capsaicin loaded lipid } \\
\text { nanoparticles to treat pain with reduced } \\
\text { skin irritation }\end{array}$ & [104] \\
\hline NLC & Azelaic acid & $\begin{array}{c}\text { Preparation of azelaic acid loaded } \\
\text { nanostructured lipid carriers for the treatment of } \\
\text { acne vulgaris }\end{array}$ & {$[64]$} \\
\hline NLC & Apremilast & $\begin{array}{c}\text { Formulation of nanostructured lipid carriers for } \\
\text { topical delivery of apremilast for } \\
\text { psoriasis treatments }\end{array}$ & [105] \\
\hline NLC & Itraconazole & $\begin{array}{l}\text { Development of topical lipid nanoparticles } \\
\text { containing itraconazole for treatment of } \\
\text { fungal infections }\end{array}$ & [106] \\
\hline NLC & Halobetasol propionate & $\begin{array}{c}\text { Formulation of nanostructured lipid carriers } \\
\text { loaded with halobetasol propionate for } \\
\text { anti-inflammatory treatment }\end{array}$ & [107] \\
\hline NLC & $\begin{array}{l}\text { Tacrolimus and tumor } \\
\text { necrosis factor } \alpha \text { siRNA }\end{array}$ & $\begin{array}{l}\text { Design of nanostructured lipid carrier } \\
\text { co-delivering tacrolimus and tumor necrosis } \\
\text { factor } \alpha \text { siRNA for the treatment of psoriasis }\end{array}$ & [108] \\
\hline NLC & Clobetasol propionate & $\begin{array}{l}\text { Preparation of nanostructured lipid carrier-based } \\
\text { controlled release topical gel of clobetasol } \\
\text { propionate for eczema treatment }\end{array}$ & [109] \\
\hline SLN & Adapalene & $\begin{array}{l}\text { Formulation of adapalene loaded solid lipid } \\
\text { nanoparticles for anti-acne therapy }\end{array}$ & [110] \\
\hline SLN & Retinoic acid & $\begin{array}{c}\text { Development of solid lipid nanoparticles loaded } \\
\text { with retinoic acid and lauric acid for acne } \\
\text { vulgaris topical treatments }\end{array}$ & [111] \\
\hline SLN & Isotretinoin and $\alpha$-tocopherol & $\begin{array}{l}\text { Formulation of isotretinoin and } \alpha \text {-tocopherol } \\
\text { acetate loaded solid lipid nanoparticles in the } \\
\text { topical gel for anti-acne activity }\end{array}$ & [112] \\
\hline NLC & Spironolactone & $\begin{array}{l}\text { Design of spironolactone loaded nanostructured } \\
\text { lipid carrier-based gel for effective treatment of } \\
\text { mild and moderate acne vulgaris }\end{array}$ & [113] \\
\hline NLC & Diflucortolone valerate & $\begin{array}{l}\text { Formulation of diflucortolone valerate loaded } \\
\text { nanostructured lipid carrier to be used as } \\
\text { anti-inflammatory sunscreen }\end{array}$ & [114] \\
\hline SLN & Aconitine & $\begin{array}{l}\text { Formulation of aconitine loaded solid lipid } \\
\text { nanoparticles for transdermal delivery for the } \\
\text { analgesic purpose }\end{array}$ & [115] \\
\hline SLN & Avanafil & $\begin{array}{c}\text { Formulation of avanafil loaded solid lipid } \\
\text { nanoparticles for transdermal delivery to treat } \\
\text { erectile dysfunction }\end{array}$ & [116] \\
\hline SLN & Colchicine & $\begin{array}{l}\text { Fabrication of colchicine loaded solid lipid } \\
\text { nanoparticles for transdermal delivery for } \\
\text { anti-gout treatment }\end{array}$ & [117] \\
\hline
\end{tabular}


Table 1. Cont.

\begin{tabular}{|c|c|c|c|}
\hline Type of Lipid Nanoparticle & Drug/Active Material & Purpose & Reference \\
\hline SLN & Curcumin & $\begin{array}{l}\text { Formulation of curcumin loaded solid lipid } \\
\text { nanoparticles for transdermal delivery for } \\
\text { antioxidant, anti-inflammatory, and } \\
\text { anti-tumor purposes }\end{array}$ & [118] \\
\hline SLN & Ivermectin & $\begin{array}{c}\text { Development of ivermectin loaded solid lipid } \\
\text { nanoparticles for transdermal delivery for } \\
\text { anti-inflammatory treatment }\end{array}$ & [119] \\
\hline NLC & Bupivacaine & $\begin{array}{l}\text { Design of hyaluronic acid-modified } \\
\text { nanostructured lipid carriers containing } \\
\text { bupivacaine for local anesthetic activity }\end{array}$ & [120] \\
\hline NLC & Diclofenac & $\begin{array}{l}\text { Preparation of diclofenac loaded nanostructured } \\
\text { lipid carriers for transdermal drug delivery for } \\
\text { anti-inflammatory treatment }\end{array}$ & [121] \\
\hline NLC & Donepezil & $\begin{array}{c}\text { Preparation of donepezil loaded nanostructured } \\
\text { lipid carriers for transdermal drug delivery for } \\
\text { cholinesterase inhibition }\end{array}$ & [92] \\
\hline NLC & Lansoprazole & $\begin{array}{l}\text { Design of lansoprazole loaded nanostructured } \\
\text { lipid carriers for transdermal drug delivery for } \\
\text { stomach infection treatment }\end{array}$ & [65] \\
\hline NLC & Pioglitazone & $\begin{array}{l}\text { Design of pioglitazone loaded nanostructured } \\
\text { lipid carriers for transdermal drug delivery as an } \\
\text { anti-hyperglycemic agent }\end{array}$ & [66] \\
\hline NLC & Rivastigmine & $\begin{array}{c}\text { Development of rivastigmine loaded } \\
\text { nanostructured lipid carriers for transdermal } \\
\text { drug delivery for treatment of dementia }\end{array}$ & [122] \\
\hline NLC & Ropivacaine & $\begin{array}{c}\text { Formulation of ropivacaine loaded } \\
\text { nanostructured lipid carriers for transdermal } \\
\text { drug delivery as an anesthetic agent }\end{array}$ & [123] \\
\hline SLN & Curcumin & $\begin{array}{l}\text { Formulation of ceramide palmitic acid } \\
\text { complex-based, curcumin containing solid lipid } \\
\text { nanoparticles for transdermal delivery for the } \\
\text { anti-inflammatory purpose }\end{array}$ & [124] \\
\hline NLC & Tadalafil & $\begin{array}{c}\text { Formulation of tadalafil loaded nanostructured } \\
\text { lipid carriers for transdermal delivery for erectile } \\
\text { dysfunction treatment }\end{array}$ & [125] \\
\hline NLC & Methotrexate & $\begin{array}{c}\text { Preparation of methotrexate loaded } \\
\text { nanostructured lipid carriers for transdermal } \\
\text { drug delivery for treatment of } \\
\text { rheumatoid arthritis }\end{array}$ & [126] \\
\hline NLC & Aceclofenac & $\begin{array}{l}\text { Preparation of aceclofenac loaded } \\
\text { nanostructured lipid carriers for transdermal } \\
\text { drug delivery for anti-inflammatory treatment }\end{array}$ & [127] \\
\hline
\end{tabular}

\section{Nanovesicular Carriers}

Conventional liposomes are considered to be the first generation of nanovesicular carriers. These are sphere-shaped vesicles comprising one or more phospholipid bilayers that enclose an inner aqueous core (Figure 4). Their size can range from $20 \mathrm{~nm}$ to several micrometers and they can have a single phospholipid bilayer (unilamellar vesicles) or multiple bilayers (multilamellar vesicles). Unilamellar vesicles are further classified into two categories: (1) small unilamellar vesicles with sizes in the range of $20-100 \mathrm{~nm}$, and (2) large unilamellar vesicles, which are larger than $100 \mathrm{~nm}$ [128]. In multilamellar 
liposomes, vesicles have an onion structure of concentric phospholipid spheres separated by layers of water [128].

Several methods exist for liposome preparation, including thin-film hydration, reverse phase evaporation, and microfluidic mixing [129]. In certain conditions, a spontaneous liposome formation can also occur [130]. The process that is employed to generate the liposomes will impact their size and lamellarity [129]. The physicochemical nature of the drug to be entrapped in the liposomes also plays a crucial role in the selection of their preparation method. Thus, the preparation methods of drug-loaded liposomes are classified into: (1) passive loading- methods in which liposomes are formed concurrently with drug loading, and (2) active loading-methods in which the liposomes that contain a transmembrane gradient, i.e., different aqueous phases inside and outside the liposomes, are first generated, and then the drug is loaded [129]. In general, passive loading can be employed either for hydrophilic compounds, which are distributed homogenously in the aqueous phase prior to liposome formation, or for lipophilic drugs, which are retained inside the lipid bilayer. In active loading, an amphipathic drug is dissolved in the exterior aqueous phase after liposome formation and permeates across the phospholipid bilayer(s), followed by interactions with a trapping agent in the core of the liposome to retain it there [129].

In 1980 Mezei and Gulasekharam reported the first generation of liposomes as possible drug delivery systems for topical administration [131]. Ever since, liposomes are widely used as dermal drug carriers $[132,133]$. The main component of liposomes is typically phospholipids, whereas cholesterol is often added to enhance the stability of liposomal bilayers by filling the gaps caused by imperfect packing [134]. Many theories are proposed for the mechanism of liposome skin penetration, such as penetration through transappendageal route, adsorption effect, intact vesicle penetration, and interaction of the membrane with SC lipids that results in its partial fluidization [135]. Notably, liposomal vesicles with sizes above $600 \mathrm{~nm}$ are typically unable to penetrate to the deep skin layers, whereas liposomes smaller than $300 \mathrm{~nm}$ can potentially reach deeper epidermal and dermal strata [136].

\section{Phospholipid bilayer}

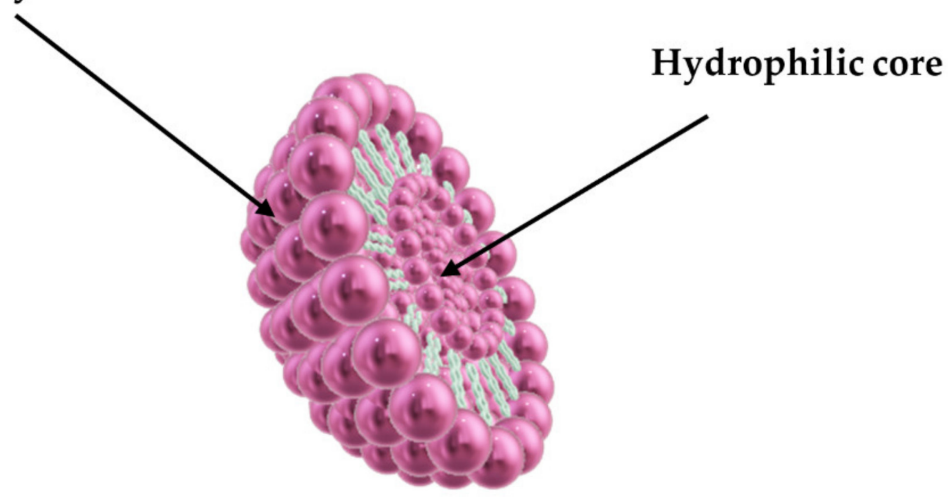

Figure 4. Schematic illustration of a conventional liposome.

The second generation of nanovesicular carriers was developed by Cevc et al. in 1992. These vesicles are called transfersomes, and they are modified liposomes that have an average diameter of under $300 \mathrm{~nm}$ and contain an edge activator. The edge activator is a bilayer softening component, such as a surface active agent that makes transfersomes up to 8 times more flexible than the conventional liposomes (Figure 5) [137-140].

Examples of edge activators are dipotassium glycyrrhizinate, sodium cholate, sorbitan esters, and polysorbates [141]. The ability of transfersomes to squeeze themselves through tiny openings, 5 to 10 times smaller than the vesicle diameter, and their multiple advantages over the conventional liposomes for cutaneous delivery have been extensively discussed [142-144]. Yet, to further improve the permeation abilities, in 1996 Touitou designed the ethosomes [145]. These vesicular systems contain a high concentration of 
ethanol ranging from 20 to $45 \mathrm{wt} \%$, which leads to the formation of fluid bilayers in their structure [140]. In fact, they are characterized by bilayers from wall to wall and, unlike liposomes or transfersomes, do not contain a core. It is also noteworthy that in contrast to liposomes, these vesicles cannot be separated from the liquid phase and the whole system is used following its preparation. Ethosomes provide a permeation enhancement effect that can occur in both occluded and nonoccluded skin conditions and results in drug penetration up to $200 \mu \mathrm{m}$ depth (Figure 5) [145-149].

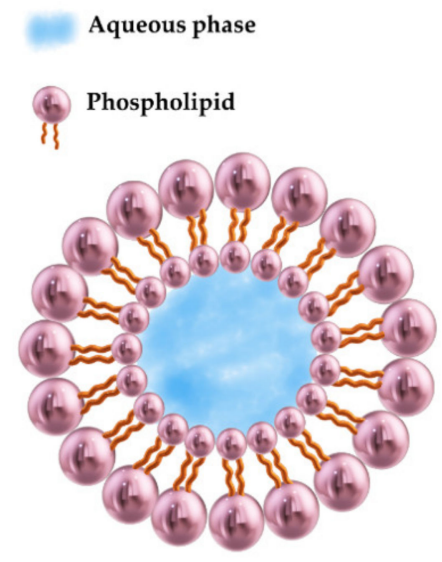

(a)

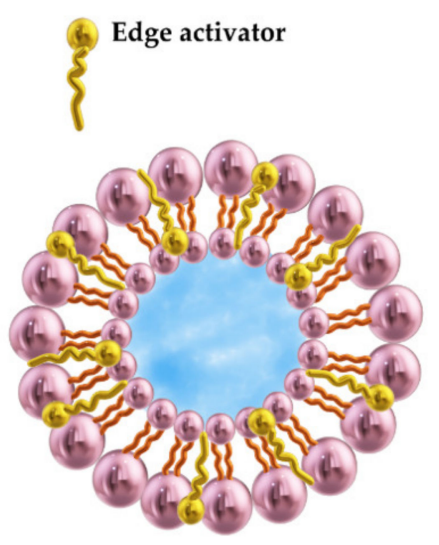

(b)

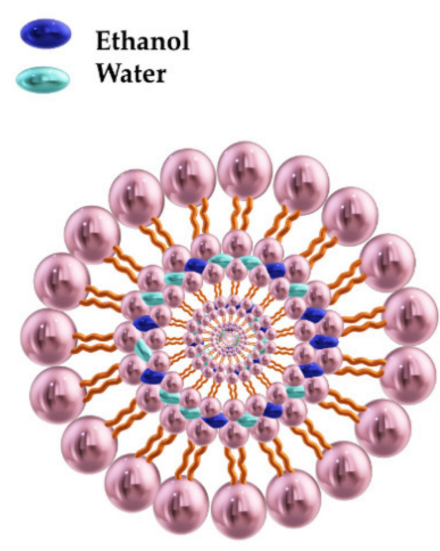

(c)

Figure 5. Membrane structure of (a) conventional liposome, (b) transfersome (with edge activators), (c) ethosome (with ethanol and water between the bilayers).

It was also found that increasing ethanol content in ethosomes leads to a decrease of their average size. However, there is a critical concentration of ethanol that may cause a destabilization due to phospholipid bilayers interdigitation [148]. Multiple studies showed the effectiveness of ethosomes for dermal drug delivery in occlusive and nonocclusive applications [141,150,151], and demonstrated their excellent ability to enhance the cutaneous permeation of drugs, including highly lipophilic and highly hydrophilic active compounds [147,152-154].

A schematic illustration of the penetration mechanisms of the nanovesicular carriers is shown in Figure 6.

Another type of the nanovesicular carrier widely used for dermal drug delivery is called niosomes [155]. These vesicles are based on nonionic surfactants and cholesterol or its derivatives and are considered to be more stable and less expensive than liposomes [135]. The type of surfactants and lipids determine the shape of the noisome, which can be ellipsoid, discoid, or polyhedral [156]. Several methods can be employed to prepare niosomes, such as high-pressure homogenization, extrusion, or sonication, and they all can yield an average particle size between 50 and $200 \mathrm{~nm}$. However, as the size of these vesicles gets smaller, the drug loading and stability deteriorate. This problem can be potentially overcome by the addition of a stabilizer [135]. Niosomes can enhance skin permeation by distortion of SC intercellular lipids and subsequent fusion with the SC, which causes a high thermodynamic activity gradient of the active compound at the vesicle-SC interface [135].

Additional nanovesicular carriers that are being increasingly explored for dermal delivery in recent years are cubosomes, hexasomes, aquasomes, colloidosomes, sphingosomes, and ufasomes $[157,158]$. Cubosomes are composed of bicontinuous cubic liquid crystalline phase with two nonintersecting hydrophilic areas separated by a lipid bilayer (Figure 7) [157-159]. Their preparation typically requires the usage of high-energy dispersion techniques $[157,160,161]$. Similarly, hexosomes are composed of hexagonal liquid crystalline phases dispersed in a continuous aqueous medium [162]. Both cubosomes and hexosomes exhibit excellent stability, increased drug loading, and the ability to incorporate hydrophilic, hydrophobic, and amphiphilic drugs (Figure 7). These vesicles are extensively 
investigated for dermal and transdermal drug deliveries [158,163,164]. For example, it was recently shown that incorporating bile salt edge activators in hexosomes can greatly enhance their skin penetration properties, favoring accumulation in deep skin layers and transdermal permeation [165].

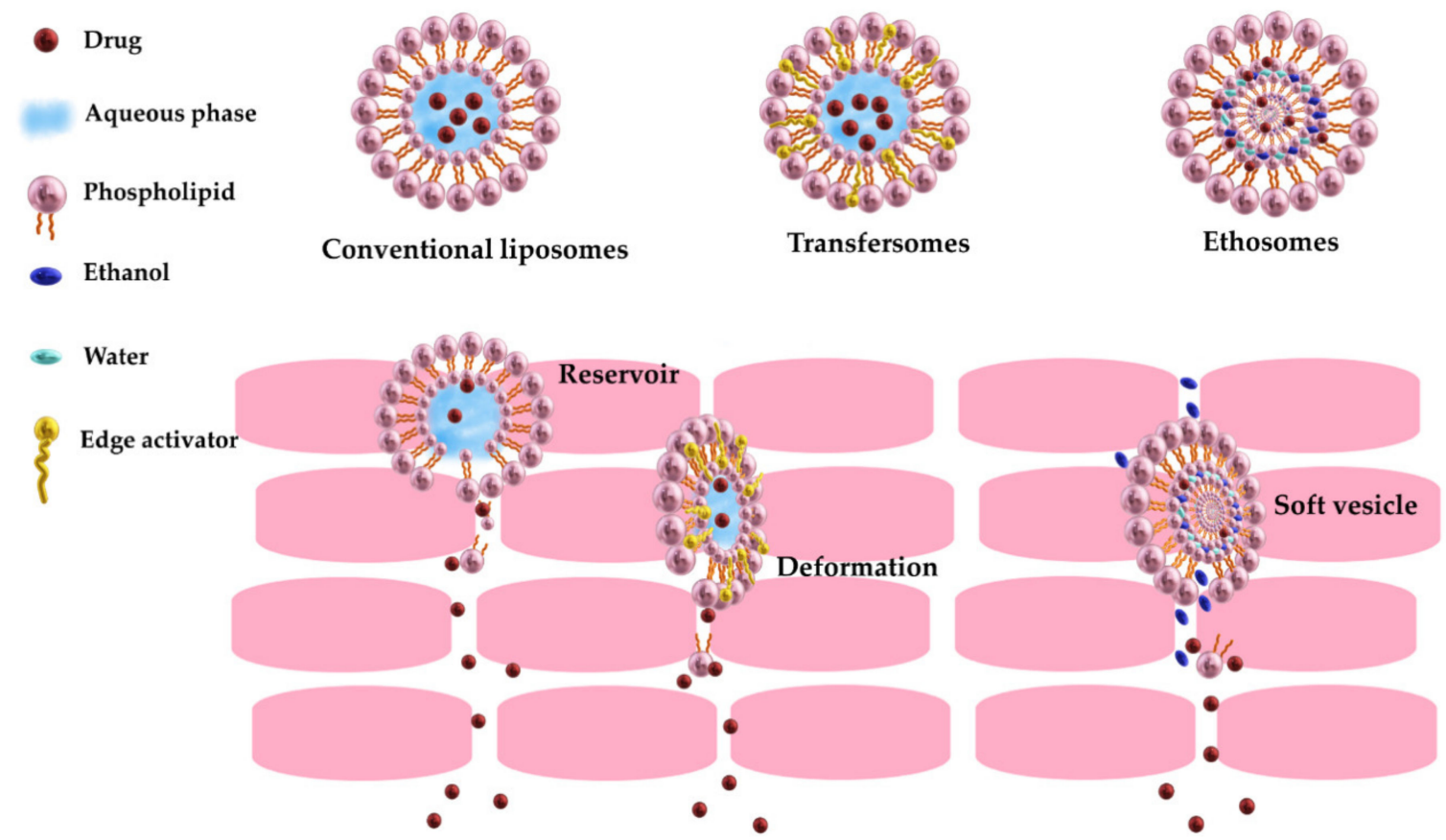

Figure 6. Schematic illustration of the penetration mechanism of conventional liposomes, transfersomes, and ethosomes.

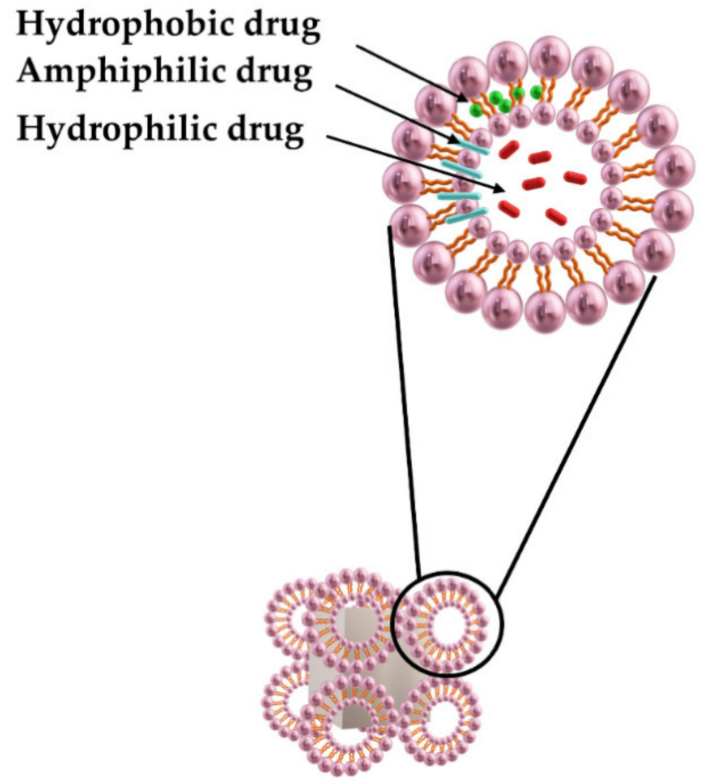

(a)

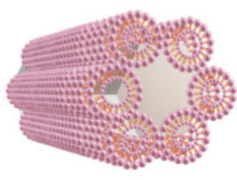

(b)

Figure 7. Schematic illustration of (a) cubosome; (b) hexosome.

Aquasomes are self-assembled nanovesicles composed of three layers: A solid nanocrystalline core, an oligomeric shell, and a layer of a bioactive substance absorbed onto the shell [157]. The techniques used for the fabrication of the core are colloidal precipitation, sonication, plasma condensation, and inverted magnetron sputtering. These nanovesicles enable a high drug loading and are capable of protecting fragile drug molecules from 
degradation [166]. Colloidosomes are hollow shell microcapsules composed of coagulated particles. These structures are typically employed to encapsulate sensitive bioactive molecules [157]. They can be prepared by self-assembly of colloidal particles at the water-oil interface in water-in-oil emulsions $[157,167]$. Sphingosomes are comprised of sphingolipids such as sphingosine, ceramide, sphingomyelin, or glycosphingolipid, and are concentric, bilayered nanovesicles with typically an acidic $\mathrm{pH}$ inside [168]. The resultant systems can be unilamellar, mutilamellar, oligolamellar, or multivesicular. Their preparation methods include mechanical dispersion, film hydration, solvent injection, sonication, reverse phase evaporation, freeze-thaw, and microfluidization. Their unique structure leads to the enhanced drug loading efficiency, low susceptibility to degradation, and long circulation time in vivo $[168,169]$. Ufasomes are composed of closed lipid bilayers derived from unsaturated fatty acids and ionic surfactants $[157,170,171]$. Compared to the conventional liposomes, ufasomes are more stable, and have a higher entrapment and drug loading efficiency, but are more prone to oxidation $[157,172]$.

Selected works on employing nanovesicular carriers in dermal drug delivery are highlighted below.

\subsection{Topical Delivery with Nanovesicular Carriers}

\subsubsection{Anticarcinogenic Activity}

Cosco et al., report on the formation of ultradeformable liposomes for combined delivery of resveratrol- and 5-fluorouracil [173]. These vesicles contained phospholipid and sodium cholate and were investigated for the treatment of non-melanoma skin cancers. The percutaneous permeation through the human $S C$ and viable epidermis membranes increased 8.3-fold for resveratrol and 6.2-fold for 5-fluorouracil when delivered by these ultradeformable liposomes compared with the free drugs. This effect may be attributed to the intact penetration and the accumulation of the vesicles in the deeper skin strata, which generates a cutaneous depot from which resveratrol and 5-fluorouracil are gradually released. The co-encapsulation of the drugs improved their anti-cancer activity on skin cancer cells as compared to both the free drugs and the individually entrapped agents [173]. Jiang et al., developed cell-penetrating peptide-modified paclitaxel containing transfersomes consisting of a phospholipid, Polysorbate 80, and sodium deoxycholate [174]. An oligopeptide hydrogel containing these transfersomes was painted as a patch over subcutaneous melanoma in mice and prolonged the retention time of the drug in the skin while enhancing the anti-cancer effect of co-administrated Taxol [174]. Cristiano et al. evaluated ethosomes and transfersomes vesicular carriers for the percutaneous delivery of sulforaphane, a natural compound that exhibits a significant antiproliferative activity, but has very poor percutaneous permeation [175]. Resultant ethosomes and transfersomes contained phospholipid and either ethanol or sodium cholate, had mean sizes below $400 \mathrm{~nm}$ and a low size polydispersity index. The stability studies demonstrated that ethosomes containing $40 \%(w / v)$ of ethanol were the most suitable carriers for the percutaneous delivery of sulforaphane. The in vitro studies with these vesicles showed an increased permeation of the active substance through the human $S C$ and epidermis membranes, and the vesicles had an enhanced anti-cancer activity compared with free sulforaphane in a melanoma cell line [175].

\subsubsection{Antipsoriatic Activity}

Abdelbary and AbouGhaly designed topical methotrexate-loaded niosomes for the management of psoriasis [176]. Psoriasis, a skin disorder characterized by impaired epidermal differentiation, is commonly treated by systemic methotrexate, an effective cytotoxic drug, but with numerous side effects, which are minimized by the local administration. The niosomes were prepared by thin-film hydration technique, and comprised a surfactant (Span 60) and cholesterol (optimal composition was 2:1 ratio). They displayed spherical morphology and had a mean particle size of around $1.4 \mu \mathrm{m}$ with a high drug encapsulation 
efficiency (79\%). The in vivo skin deposition study in rats showed the increased drug deposition in the skin from niosomal formulation compared with the free drug solution.

\subsubsection{Local Anesthetic Activity}

Babaie et al. prepared lidocaine loaded-nanometric ethosomes (nanoethosomes) for penetration into deep strata of the skin [177]. The particle size of the optimized formulation was around $100 \mathrm{~nm}$ and the ethosomes had strongly negative zeta potential. Surprisingly, it was found that increasing the concentration of ethanol from $10 \%$ to $40 \%$ resulted in the production of ethosomes with 4-times larger particle size. It was assumed that elevating ethanol percentage disrupted the vesicle membrane and subsequently increased the vesicle size. The in vivo penetration studies in rat skin showed that nanoethosomes could enhance model dye penetration through the SC into the lower layers of the epidermis, while the same dye in the hydroethanolic solution remained mostly in the SC.

\subsubsection{Antifungal Activity}

Perez et al. prepared ultradeformable liposomes containing amphotericin B for the treatment of cutaneous fungal infections and leishmaniasis [178]. The effects of different edge activators, phospholipid and drug concentration, and phospholipid to edge activator ratio on liposomal deformability, as well as on the drug liposomal content, were tested. Liposomes comprising Tween 80 as an edge activator had maximal deformability and the highest drug/phospholipid ratio. They had an average vesicle diameter of around $110 \mathrm{~nm}$ and almost neutral zeta potential. Amphotericin B was encapsulated in their bilayer at 75\% encapsulation efficiency. Drug-loaded liposomes were more toxic to fungal strains than to mammalian cells. The accumulation of amphotericin B in the excised human skin was tested after $1 \mathrm{~h}$ of non-occlusive incubation and was found to be 40 times higher from the ultradeformable liposomes than from the commercial liposomal preparation, AmBisome ${ }^{\circledR}$.

\subsubsection{Anti-vitiligo Activity}

Garg et al. developed nanosized ethosome-based hydrogel formulations of methoxsalen for enhanced topical delivery and effective treatment of vitiligo [179]. The optimized ethosomal formulation contained approximately $28 \%$ of ethanol and had a mean vesicle diameter of $280 \mathrm{~nm}$. These ethosomes were subsequently incorporated into carbopol gel and showed a significant skin permeation through rat skin, with accumulation in epidermal and dermal layers. Also, the developed formulation caused reduced skin phototoxicity and erythema compared with the conventional cream.

\subsubsection{Antibiotic Activity}

In 2005 Godin et al. developed ethosomal system as a new approach for dermal delivery of antibiotics to enhance their permeation through the $S C$ to the deeper skin layers, as well as the penetration through bacterial membrane/cell wall [180,181]. Recently, Zahid et al., formulated ethosomes containing clindamycin phosphate by using a cold method [182]. The resulted system comprised spherical vesicles with an average size of $110 \mathrm{~nm}$ and showed high clindamycin entrapment efficiency of around $82 \%$. Then, the optimized formulation was incorporated into carbopol gel and demonstrated an excellent in vitro drug release, which followed zero-order kinetics [182].

\subsubsection{Antiviral Activity}

Acyclovir has been extensively investigated for topical treatment of viral infections since the introduction of this synthetic acyclic nucleoside analog more than four decades ago [183]. In 1999, Horwitz et al. developed an ethosomal carrier system for acyclovir, which improved its clinical efficacy compared with commercial Zovirax ${ }^{\circledR}$ cream in a clinical study [184]. Recently, Shukla et al. developed an ethosomal gel system of acyclovir, in which the ethosomes were prepared by the cold method [185]. The ethosomes in the optimized system had a mean vesicle size of around $330 \mathrm{~nm}, 80 \%$ drug entrapment, and 
zeta potential of $-21 \mathrm{mV}$. The system showed in vitro drug release of $82 \%$ over $8 \mathrm{~h}$ with a zero-order release profile [185].

\subsubsection{Anti-acne Activity}

The two major processes involved in acne vulgaris (known as acne) pathophysiology are (1) proliferation of propionibacterium acnes bacteria in pilosebaceous units of the skin, and (2) local inflammation [186]. Topical anti-acne agents typically cause adverse effects such as burning, scaling, photosensitivity, erythema, flare-up, and bacterial resistance [187]. In 2008 Touitou et al. designed an ethosomal system containing clindamycin phosphate and salicylic acid gel for the efficient delivery of these drugs to pilosebaceous units as well as for enhanced topical tolerability [186]. In a recent work Apriani et al. developed azelaic acid ethosome-based cream against propionibacterium acnes [188]. Azelaic acid exhibits an anti-acne effect by inhibiting thioredoxin reductase enzyme of propionibacterium acnes, and must penetrate through the stratum corneum to the sebaceous tissue and into the cytoplasm of the bacteria in order to act, and therefore benefits from incorporation in ethosomes. The ethosomes were prepared by the thin-layer hydration method and had a particle size of below $200 \mathrm{~nm}$. The ethosomal cream demonstrated a superior antibactericidal activity compared with the marketed cream Zelface ${ }^{\circledR}$ [188].

\subsection{Transdermal Delivery with Nanovesicular Carriers}

In 2003, Lodzki et al. proposed ethosomal carriers as an efficient system for enhancing the transdermal delivery of cannabidiol for anti-inflammatory treatments [189]. Later on, Shumilov et al. developed two ethosomal systems for transdermal delivery of ibuprofen and buspirone $[4,190]$. In a recent work, Shuwaili et al. designed transfersomal system for transdermal delivery of pentoxifylline, a xanthine derivative indicated in chronic occlusive arterial diseases [191]. Pentoxifylline has low oral bioavailability and a short half-life; and thus, it is a good candidate for transdermal delivery. The transfersomes comprised sodium cholate and nonionic surfactants as edge activators, exhibited drug entrapment efficiency of $75 \%$, vesicles elasticity of $145 \mathrm{mg} \mathrm{s}^{-1} \mathrm{~cm}^{-2}$, zeta potential of $-35 \mathrm{mV}$, average vesicle diameter of $700 \mathrm{~nm}$, and permeation flux of $56 \mu \mathrm{g} / \mathrm{cm}^{2} / \mathrm{h}$. They enhanced drug permeation through the excised rat skin by up to 9 -fold compared with pentoxifylline solution. Results of the in vivo pharmacokinetic study in healthy human volunteers showed that transfersomal formulation increased the amount of the drug absorbed into the circulation over time and maintained higher plasma levels comparing with the commercial oral SR tablets (Trental ${ }^{\mathrm{TM}} 400 \mathrm{mg}$ ), which could be attributed to the avoidance of the first-pass effect [191]. Qumbar et al. formed transdermal lacidipineloaded niosomes for the management of hypertension [192]. Niosomes were prepared by the thin-film hydration technique and had an average size of around $700 \mathrm{~nm}$, and a flux value of $38.43 \mu \mathrm{g} / \mathrm{cm}^{2} / \mathrm{h}$ for the optimized noisome-containing gel. The blood pressure decrease caused by the transdermal niosomal gel was compared to the decrease caused by oral lacidipine suspension and was found to produce a more gradual effect, controlling the blood pressure up to $48 \mathrm{~h}$ [192].

Additional works demonstrating employment of nanovesicular carriers in dermal drug delivery are summarised in Table 2.

Table 2. Recent studies on dermal/transdermal drug delivery systems comprising nanovesicular carriers.

\begin{tabular}{cccc}
\hline Type of Lipid-Based Nanoparticle & Drug/Active Material & Purpose & Reference \\
\hline Niosomes & Methotrexate & $\begin{array}{c}\text { Design of topical methotrexate loaded } \\
\text { niosomes for management of psoriasis }\end{array} \quad$ [176] & $\begin{array}{c}\text { Formulation of resveratrol loaded } \\
\text { niosomes for skin cancer and } \\
\text { psoriasis treatment }\end{array}$ \\
\hline Niosomes & Resveratrol & [193] \\
\hline
\end{tabular}


Table 2. Cont.

\begin{tabular}{|c|c|c|c|}
\hline Type of Lipid-Based Nanoparticle & Drug/Active Material & Purpose & Reference \\
\hline Niosomes & Benzoyl peroxide & $\begin{array}{c}\text { Development of benzoyl peroxide } \\
\text { loaded niosomes for } \\
\text { anti-acne treatment }\end{array}$ & [194] \\
\hline Niosomes & Benzoyl peroxide and tretinoin & $\begin{array}{l}\text { Design of noisome gel containing } \\
\text { benzoyl peroxide and tretinoin for } \\
\text { anti-acne activity }\end{array}$ & [195] \\
\hline Transfersomes + ethosomes & Ginsenoside Rh1 & $\begin{array}{l}\text { Formulation of transfersomes and } \\
\text { ethosomes containing ginsenoside Rh1 } \\
\text { from red ginseng for treatment of } \\
\text { tumors, inflammation, diabetes, stress, } \\
\text { and acquired } \\
\text { immunodeficiency syndrome }\end{array}$ & [196] \\
\hline Transfersomes & Capsaicin & $\begin{array}{c}\text { Formulation of capsaicin loaded } \\
\text { transfersomes for } \\
\text { anti-inflammatory treatment }\end{array}$ & [197] \\
\hline Transfersomes & Indocyanine green & $\begin{array}{l}\text { Preparation of indocyanine green } \\
\text { loaded transfersomes for acne vulgaris }\end{array}$ & [198] \\
\hline Ethosomes & Lidocaine & $\begin{array}{c}\text { Development of lidocaine loaded } \\
\text { ethosomes for topical delivery } \\
\text { of anesthetics }\end{array}$ & [177] \\
\hline Ethosomes & 5-Fluorouracil & $\begin{array}{c}\text { Development of ethosomes containing } \\
\text { 5-fluorouracil as a novel therapy for } \\
\text { laryngotracheal stenosis }\end{array}$ & [199] \\
\hline Conventional liposomes & Licorice & $\begin{array}{c}\text { Formulation of licorice loaded } \\
\text { liposomes for treatments of oxidative } \\
\text { stress injuries }\end{array}$ & [200] \\
\hline Transfersomes & 5-Fluorouracil & $\begin{array}{l}\text { Design of 5-fluorouracil loaded } \\
\text { transfersomes for skin } \\
\text { cancer treatments }\end{array}$ & [201] \\
\hline Transfersomes & Resveratrol and 5-fluorouracil & $\begin{array}{c}\text { Preparation of transfersomes } \\
\text { containing resveratrol for skin } \\
\text { cancer treatments }\end{array}$ & [173] \\
\hline Niosomes & Diacerein & $\begin{array}{c}\text { Formulation of niosomes for topical } \\
\text { diacerein delivery for treatment } \\
\text { of psoriasis }\end{array}$ & [202] \\
\hline Transfersomes & Amphotericin B & $\begin{array}{c}\text { Development of amphotericin B loaded } \\
\text { transfersomes for antifungal and } \\
\text { antileishmanial treatments }\end{array}$ & [178] \\
\hline Conventional liposomes & Quercetin and resveratrol & $\begin{array}{l}\text { Formulation of quercetin and } \\
\text { resveratrol loaded liposomes for } \\
\text { treatment of inflammatory/oxidative } \\
\text { response associated with skin cancer }\end{array}$ & [203] \\
\hline Transfersomes & siRNA & $\begin{array}{l}\text { Development of transfersomes } \\
\text { containing siRNA to deliver to the } \\
\text { human basal epidermis for } \\
\text { melanoma therapy }\end{array}$ & [204] \\
\hline Transfersomes & RNAi & $\begin{array}{l}\text { Formulation of transfersomes } \\
\text { containing RNAi for } \\
\text { psoriasis treatments }\end{array}$ & [205] \\
\hline Niosomes & Moxifloxacin & $\begin{array}{l}\text { Design of chitosan gel embedded } \\
\text { moxifloxacin niosomes for burn } \\
\text { infection treatment }\end{array}$ & [206] \\
\hline
\end{tabular}


Table 2. Cont.

\begin{tabular}{|c|c|c|c|}
\hline Type of Lipid-Based Nanoparticle & Drug/Active Material & Purpose & Reference \\
\hline Niosomes & Zingiber cassumunar roxburgh & $\begin{array}{l}\text { Formulation of niosomes containing } \\
\text { zingiber cassumunar roxburgh for } \\
\text { anti-inflammatory activity }\end{array}$ & [207] \\
\hline Transfersomes & Asenapine & $\begin{array}{l}\text { Preparation of nano transfersomes } \\
\text { containing asenapine maleate for } \\
\text { transdermal delivery for treatment of } \\
\text { schizophrenia and bipolar disorder }\end{array}$ & [208] \\
\hline Transfersomes & Ketoprofen & $\begin{array}{l}\text { Development of ketoprofen loaded } \\
\text { transfersomes for treatment of muscle } \\
\text { soreness following exercise }\end{array}$ & [209] \\
\hline Ethosomes & Methoxsalen & $\begin{array}{l}\text { Formulation of ethosomes containing } \\
\text { methoxsalen for topical delivery } \\
\text { against vitiligo }\end{array}$ & [179] \\
\hline Ethosomes & Griseofulvin & $\begin{array}{l}\text { Design of griseofulvin loaded } \\
\text { ethosomes for antifungal treatments }\end{array}$ & [210] \\
\hline Ethosomes & Aceclofenac & $\begin{array}{l}\text { Formulation of ethosomes containing } \\
\text { aceclofenac for treatment of pain } \\
\text { and inflammation }\end{array}$ & [211] \\
\hline Ethosomes & Cryptotanshinone & $\begin{array}{c}\text { Formulation of cryptotanshinone } \\
\text { loaded ethosomes for } \\
\text { anti-acne treatments }\end{array}$ & [212] \\
\hline Niosomes & Pregabalin & $\begin{array}{l}\text { Preparation of pregabalin loaded } \\
\text { niosomes as } \\
\text { anti-inflammatory treatments }\end{array}$ & [213] \\
\hline Niosomes & 8-Methoxypsoralen & $\begin{array}{l}\text { Development of niosomes containing } \\
\text { 8-methoxypsoralen for } \\
\text { photochemotherapeutic treatments }\end{array}$ & [214] \\
\hline Niosomes & Acyclovir & $\begin{array}{l}\text { Preparation of acyclovir loaded } \\
\text { niosomes for treatments of herpes }\end{array}$ & [215] \\
\hline Niosomes & Inositol hexaphosphate & $\begin{array}{c}\text { Formulation of inositol hexaphosphate } \\
\text { loaded niosomes as an } \\
\text { antiangiogenic agent }\end{array}$ & [216] \\
\hline Transfersomes & Indocyanine & $\begin{array}{c}\text { Formulation of indocyanine loaded } \\
\text { transfersomes for the treatment of basal } \\
\text { cell carcinoma }\end{array}$ & [217] \\
\hline Transfersomes & Clindamycin & $\begin{array}{l}\text { Formulation of development of } \\
\text { clindamycin loaded transfersomes for } \\
\text { the treatment of acne }\end{array}$ & [218] \\
\hline Ethosomes & Phenylethyl resorcinol & $\begin{array}{l}\text { Design of phenylethyl resorcinol } \\
\text { loaded ethosomes for skin } \\
\text { lightening applications }\end{array}$ & [219] \\
\hline Niosomes & Melatonin & $\begin{array}{l}\text { Preparation of melatonin loaded } \\
\text { niosomes to induce daytime sleep } \\
\text { in children }\end{array}$ & [220] \\
\hline Transfersomes & Paclitaxel & $\begin{array}{l}\text { Development of transfersomes } \\
\text { containing paclitaxel and modified by a } \\
\text { cell-penetrating-peptide embedded in } \\
\text { oligopeptide hydrogel for topical } \\
\text { treatment of melanoma }\end{array}$ & [174] \\
\hline Transfersomes & Sodium stibogluconate & $\begin{array}{c}\text { Formulation of sodium stibogluconate } \\
\text { loaded transfersomes for treatment } \\
\text { of leishmaniasis }\end{array}$ & [221] \\
\hline
\end{tabular}


Table 2. Cont.

\begin{tabular}{|c|c|c|c|}
\hline Type of Lipid-Based Nanoparticle & Drug/Active Material & Purpose & Reference \\
\hline Niosomes & Natamycin & $\begin{array}{c}\text { Formulation of natamycin loaded } \\
\text { niosomes for treatment of } \\
\text { fungal keratitis }\end{array}$ & [222] \\
\hline Niosomes & Celastrol & $\begin{array}{l}\text { Preparation of celastrol loaded } \\
\text { niosomes for treatment of psoriasis }\end{array}$ & [223] \\
\hline Niosomes & $\begin{array}{l}\text { Artemisone, clofazimine and } \\
\text { decoquinate }\end{array}$ & $\begin{array}{l}\text { Preparation of artemisone, clofazimine, } \\
\text { and decoquinate encapsulated in } \\
\text { niosomes for } \\
\text { mycobacterium tuberculosis }\end{array}$ & [224] \\
\hline Niosomes & Pregabalin & $\begin{array}{l}\text { Development of pregabalin loaded } \\
\text { niosomes for fibromyalgia treatment }\end{array}$ & [213] \\
\hline Transfersomes & Lidocaine & $\begin{array}{c}\text { Development of lidocaine loaded } \\
\text { transfersomes for local } \\
\text { anesthetic activity }\end{array}$ & [225] \\
\hline Ethosomes & Curcumin & $\begin{array}{l}\text { Formulation of ethosomes containing } \\
\text { curcumin for } \\
\text { anti-inflammatory treatment }\end{array}$ & [226] \\
\hline Ethosomes & Epigallocatechin-3-gallate & $\begin{array}{c}\text { Formulation of } \\
\text { epigallocatechin-3-gallate loaded } \\
\text { ethosomes for treatment of skin cancer }\end{array}$ & [227] \\
\hline Ethosomes & Thymoquinone & $\begin{array}{l}\text { Formulation of topical thymoquinone } \\
\text { loaded ethosomes for treatment of acne }\end{array}$ & [228] \\
\hline Transfersomes & Sulforaphane & $\begin{array}{c}\text { Preparation of transfersomes } \\
\text { containing sulforaphane for treatment } \\
\text { of skin cancer }\end{array}$ & [175] \\
\hline Transfersomes & Miltefosine polyphenol & $\begin{array}{l}\text { Formulation of miltefosine polyphenol } \\
\text { loaded transfersomes for topical } \\
\text { treatment of cutaneous leishmaniasis }\end{array}$ & [229] \\
\hline Ethosomes & Harmine & $\begin{array}{c}\text { Formulation of harmine loaded } \\
\text { ethosomes for transdermal delivery for } \\
\text { anti-inflammatory treatment }\end{array}$ & [230] \\
\hline Ethosomes & Vismodegib & $\begin{array}{l}\text { Preparation of ethosomes containing } \\
\text { vismodegib for the treatment of basal } \\
\text { cell carcinoma }\end{array}$ & [231] \\
\hline Ethosomes & Clobetasol propionate & $\begin{array}{l}\text { Formulation and evaluation of } \\
\text { ethosomes of clobetasol propionate for } \\
\text { eczema treatment }\end{array}$ & [232] \\
\hline Liposomes & Tretinoin & $\begin{array}{l}\text { Formulation of tretinoin loaded } \\
\text { liposomal formulations for the } \\
\text { treatment of acne }\end{array}$ & [233] \\
\hline Liposomes & Benzoyl peroxide & $\begin{array}{l}\text { Encapsulation of benzoyl peroxide and } \\
\text { chloramphenicol in liposomes for } \\
\text { anti-acne treatments }\end{array}$ & [234] \\
\hline Liposomes & Clindamycin & $\begin{array}{c}\text { Formulation of clindamycin loaded } \\
\text { liposomal gel for effective treatment } \\
\text { of acne }\end{array}$ & [235] \\
\hline Liposomes & Benzoyl peroxide and adapalene & $\begin{array}{l}\text { Development of benzoyl peroxide and } \\
\text { adapalene loaded modified liposomal } \\
\text { gel for improved acne therapy }\end{array}$ & [236] \\
\hline Ethosomes & Tretinoin & $\begin{array}{l}\text { Formulation and evaluation of gel } \\
\text { containing tretinoin loaded ethosomes } \\
\text { for anti-acne treatments }\end{array}$ & [237] \\
\hline
\end{tabular}


Table 2. Cont.

\begin{tabular}{|c|c|c|c|}
\hline Type of Lipid-Based Nanoparticle & Drug/Active Material & Purpose & Reference \\
\hline Ethosomes & Azelaic acid & $\begin{array}{l}\text { Formulation of azelaic acid loaded } \\
\text { ethosomes for anti-acne treatments }\end{array}$ & [188] \\
\hline Niosomes & Roxithromycin & $\begin{array}{l}\text { Development of roxithromycin } \\
\text { solid-state loaded niosomes for } \\
\text { acne therapy }\end{array}$ & [238] \\
\hline Transfersome & N-acetylcysteine & $\begin{array}{l}\text { Formulation of } \mathrm{n} \text {-acetylcysteine loaded } \\
\text { transfersomes for antioxidant activity } \\
\text { in anti-aging cream }\end{array}$ & [239] \\
\hline Liposomes & Oxaprozin & $\begin{array}{l}\text { Formulation of oxaprozin loaded } \\
\text { liposomes for transdermal delivery for } \\
\text { anti-inflammatory activity }\end{array}$ & [240] \\
\hline Niosomes & Ursolic acid & $\begin{array}{l}\text { Formulation of ursolic acid loaded } \\
\text { niosomes for transdermal delivery for } \\
\text { anti-arthritic activity }\end{array}$ & [241] \\
\hline Transfersomes & pentoxifylline & $\begin{array}{l}\text { Formulation of pentoxifylline loaded } \\
\text { transfersomes for transdermal delivery } \\
\text { for treatment of chronic occlusive } \\
\text { arterial diseases }\end{array}$ & [191] \\
\hline Niosomes & Lacidipine & $\begin{array}{l}\text { Formulation of lacidipine loaded } \\
\text { niosomes for transdermal delivery for } \\
\text { anti-hypertensive activity }\end{array}$ & [192] \\
\hline Niosomes & Pumpkin seed oil & $\begin{array}{l}\text { Formulation of pumpkin seed oil } \\
\text { loaded niosomes for many applications } \\
\text { such as cardiovascular health boost, } \\
\text { treatment of benign prostatic } \\
\text { hyperplasia, reduction of hair loss, and } \\
\text { as an antioxidant agent }\end{array}$ & [242] \\
\hline Niosomes & Celecoxib & $\begin{array}{l}\text { Formulation of celecoxib loaded } \\
\text { niosomes for transdermal delivery for } \\
\text { anti-inflammatory activity }\end{array}$ & [243] \\
\hline Transfersomes & Risperidone & $\begin{array}{l}\text { Formulation of risperidone loaded } \\
\text { transfersomes for transdermal delivery } \\
\text { for antipsychotic treatment }\end{array}$ & [244] \\
\hline Transfersomes & Ondansetron & $\begin{array}{l}\text { Formulation of risperidone loaded } \\
\text { transfersomes for transdermal delivery } \\
\text { for management of chemotherapy/ } \\
\text { radiotherapy-induced nausea } \\
\text { and vomiting }\end{array}$ & [245] \\
\hline Transfersomes & $\begin{array}{l}\text { Recombinant human epidermal } \\
\text { growth factor }\end{array}$ & $\begin{array}{l}\text { Formulation of recombinant human } \\
\text { epidermal growth factor loaded } \\
\text { transfersomal emulgel for } \\
\text { anti-aging purposes }\end{array}$ & [246] \\
\hline Cubosomes & $\begin{array}{l}\text { antimicrobial peptide (AMP) } \\
\text { LL-37 }\end{array}$ & $\begin{array}{l}\text { Formulation of cubosomes for topical } \\
\text { delivery of the antimicrobial peptide } \\
\text { (AMP) LL- } 37 \text { for treatment of skin } \\
\text { infections caused by bacteria }\end{array}$ & [247] \\
\hline Cubosomes & Miconazole & $\begin{array}{c}\text { Formulation of miconazole } \\
\text { nitrate-based cubosome hydrogels for } \\
\text { antifungal treatments }\end{array}$ & [248] \\
\hline Cubosomes & $\begin{array}{c}\text { silver sulfadiazine (SSD) and Aloe } \\
\text { vera }\end{array}$ & $\begin{array}{l}\text { Formulation of cubosomes loaded with } \\
\text { silver sulfadiazine and aloe vera for } \\
\text { topical treatment of infected burns }\end{array}$ & [249] \\
\hline
\end{tabular}


Table 2. Cont.

\begin{tabular}{|c|c|c|c|}
\hline Type of Lipid-Based Nanoparticle & Drug/Active Material & Purpose & Reference \\
\hline Cubosomes & Erythromycin & $\begin{array}{l}\text { Formulation of erythromycin loaded } \\
\text { cubosomes for treatments of acne }\end{array}$ & [250] \\
\hline Cubosomes & Tretinoin & $\begin{array}{l}\text { Formulation of tretinoin loaded } \\
\text { cubosomes for treatments of acne }\end{array}$ & [251] \\
\hline Cubosomes & Fluconazole & $\begin{array}{l}\text { Formulation of fluconazole loaded } \\
\text { cubosomes for antifungal treatments }\end{array}$ & [252] \\
\hline Hexosomes, cubosomes & Ketoconazole & $\begin{array}{l}\text { Formulation of ketoconazole loaded } \\
\text { hexosomes for antifungal treatments }\end{array}$ & {$[253,254]$} \\
\hline Hexosomes, cubosomes & Catechin & $\begin{array}{l}\text { Formulation of catechin loaded } \\
\text { cubosomes and hexosomes for } \\
\text { antioxidant applications }\end{array}$ & [165] \\
\hline Ufasomes & Minoxidil & $\begin{array}{l}\text { Formulation of minoxidil loaded } \\
\text { ufasomes for hair loss treatments }\end{array}$ & [255] \\
\hline Cubosomes and hexosomes & Corcin & $\begin{array}{l}\text { Formulation of corcin loaded } \\
\text { cubosomes and hexosomes for } \\
\text { antioxidant applications }\end{array}$ & [256] \\
\hline Cubosomes & Dapsone & $\begin{array}{l}\text { Formulation of dapsone loaded } \\
\text { cubosomes for antibiotic activity }\end{array}$ & [257] \\
\hline Cubosomes & Etodolac & $\begin{array}{l}\text { Formulation of etodolac loaded } \\
\text { cubosomes for topical pain relief }\end{array}$ & [258] \\
\hline Cubosomes & Capsaicin & $\begin{array}{l}\text { Formulation of capsaicin loaded } \\
\text { cubosomes for treatments of psoriasis, } \\
\text { pruritus, apocrine chromhidrosis, and } \\
\text { contact allergy }\end{array}$ & [259] \\
\hline Cubosomes & Paclitaxel & $\begin{array}{l}\text { Formulation of paclitaxel loaded } \\
\text { cubosomes against skin cancer }\end{array}$ & [260] \\
\hline Cubosomes & Methotrexate & $\begin{array}{l}\text { Formulation of methotrexate loaded } \\
\text { cubosomes for topical treatment of } \\
\text { rheumatoid arthritis }\end{array}$ & [261] \\
\hline Cubosomes & Paeonol & $\begin{array}{l}\text { Formulation of paeonol loaded } \\
\text { cubosomes for } \\
\text { anti-inflammation treatments }\end{array}$ & [262] \\
\hline Cubosomes & Lornoxicam & $\begin{array}{l}\text { Formulation of lornoxicam loaded } \\
\text { cubosomes for } \\
\text { anti-inflammation treatments }\end{array}$ & [263] \\
\hline Cubosomes & Resveratrol & $\begin{array}{l}\text { Formulation of resveratrol loaded } \\
\text { cubosomes for anti-aging and } \\
\text { anti-cancer treatments }\end{array}$ & {$[264,265]$} \\
\hline Cubosomes & Progesterone & $\begin{array}{l}\text { Formulation of progesterone loaded } \\
\text { cubosomes for topical use to balance } \\
\text { and neutralize the effects of } \\
\text { excess estrogen }\end{array}$ & [266] \\
\hline Cubosomes & Ketoprofen & $\begin{array}{l}\text { Formulation of ketoprofen loaded } \\
\text { cubosomes for treatments of arthritis }\end{array}$ & [267] \\
\hline Cubosomes & Curcumin & $\begin{array}{c}\text { Formulation of curcumin loaded } \\
\text { cubosomes for antibacterial activities }\end{array}$ & [268] \\
\hline Cubosomes & Alpha lipoic acid & $\begin{array}{l}\text { Formulation of alpha-lipoic acid loaded } \\
\text { cubosomes for anti-aging }\end{array}$ & [269] \\
\hline
\end{tabular}




\section{Microemulsions and Nanoemulsions}

Microemulsions and nanoemulsions are nanometric dispersive systems of two immiscible liquid phases that offer several advantages over the traditional topical drug delivery formulations due to their capacity to penetrate to deeper skin strata [270]. There is evidence that they are able to disrupt the structural order of the $S C$ lipids, which leads to the loss of the barrier properties of the skin [271]. Both systems are low viscosity colloidal dispersions, but despite the apparent similarities between them, they are classified as completely different formulations [272,273]. Microemulsions are thermodynamically stable and they form spontaneously when the precise amounts of immiscible liquids (typically oil and water) and surface active agents are mixed together at the specific conditions of pressure and temperature [274,275]. Co-surfactants, such as short alkyl chain alcohols, are typically required for the spontaneous formation of microemulsions. No high-shear forces are needed to be applied to form this isotropic and visually transparent system, in which the droplet size is usually below $100 \mathrm{~nm}$ [276-278]. By modifying the ratio between the components of the microemulsion or the chemical nature of the surfactants, various structural types of microemulsions can be formed. Three main structural types of these systems are: (1) oil-in-water $(\mathrm{O} / \mathrm{W})$ microemulsion, in which nanometric droplets of oil (organic phase) are distributed throughout the aqueous phase, (2) water-in-oil (W/O) microemulsion, in which nanometric aqueous droplets are dispersed in the continuous organic phase, and (3) bicontinuous microemulsion, in which organic and aqueous phases form interdispersed nanometric domains $[279,280]$. Figure 8 illustrates the first two structural types of microemulsions. Nanoemulsions, on the other hand, can reach the droplet size of $250 \mathrm{~nm}$ and their appearance may vary between milky, translucent, and transparent depending on the droplet size [273]. These systems are kinetically stable owning to the presence of the surface active agents on the oil-water interface (typically at lower concentrations than in microemulsions), but there is no thermodynamic stability, and therefore droplet size should be assessed periodically for stability evaluation. External energy has to be typically applied in the process of nanoemulsion formation to bring the droplet size to the nanoscale [281,282].

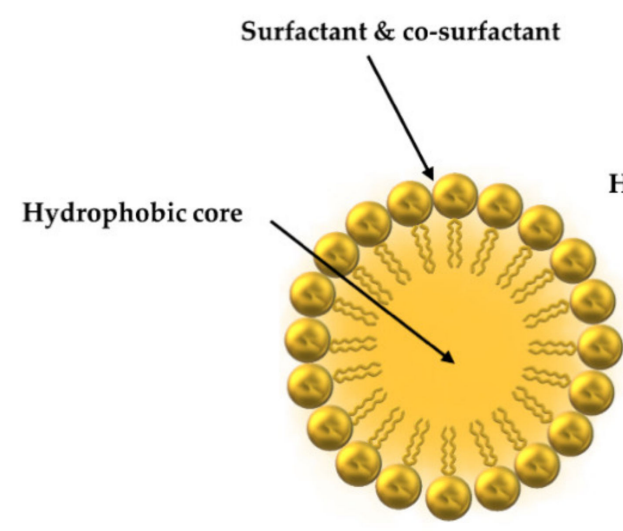

(a)

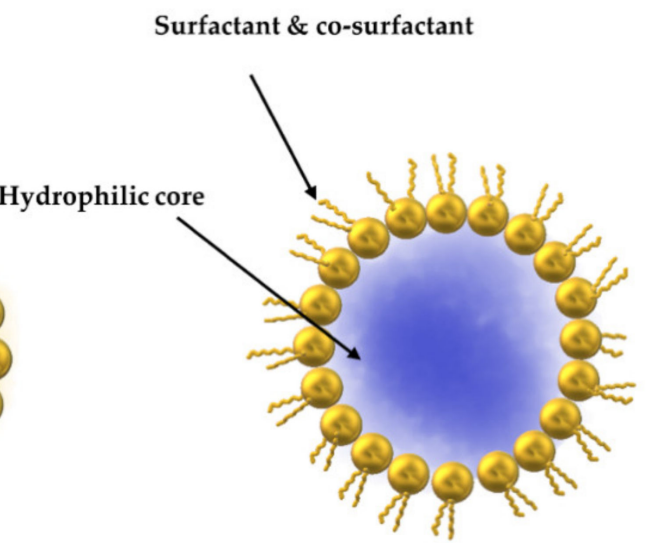

(b)

Figure 8. Schematic illustration of (a) O/W microemulsion system, (b) W/O microemulsion system.

Two major categories of preparation methods are employed to form nanoemulsions. The first category is high-energy emulsification methods, such as high-pressure homogenization, microfluidization, jet dispersing, and ultrasonication. The second category is low energy emulsification methods, which use only the physicochemical properties of the system, such as phase inversion, spontaneous emulsification, and solvent displacement [283]. Several recent works on cutaneous drug delivery with formulations based on nanoemulsions and microemulsions are detailed herein. 


\subsection{Topical Delivery with Microemulsions and Nanoemulsions \\ 4.1.1. Anti-inflammatory Activity}

Alvarado et al. designed two nanoemulsion systems for dermal administration of natural or synthetic mixtures of pentacyclic triterpenes, which exhibit anti-inflammatory activity [284]. The average droplet size of the optimized nanoemulsions ranged between 140 and $590 \mathrm{~nm}$. Larger than typical droplet size was attributed to the high molar mass of the loaded compounds. Natural and synthetic triterpene-containing formulations showed slightly different permeation profiles, whereas synthetic mixture permeated faster. The overall amount of triterpenes retained in the skin was higher than the amount of compounds permeated through the skin for both formulations, indicating the suitability of the nanoemulsion systems for the local topical delivery. The nanoemulsion with the natural triterpene mixture demonstrated greater anti-inflammatory ability in the mouse ear inflammation model than the one with the synthetic mixture, probably due to the slower permeation through the skin of the former [284]. Goindi et al. report on an ionic liquid-in-water microemulsion formulation that can solubilize etodolac, a poorly watersoluble anti-inflammatory drug [285]. The average droplet size of this microemulsion was $32 \mathrm{~nm}$, and it had almost neutral zeta potential. The ex vivo permeation studies showed a better permeation profile of drug-loaded ionic liquid-in-water microemulsion over the oil-in-water microemulsion and a solution of etodolac in oil, probably owing to the better drug solubilization and penetration enhancing effect of the ionic liquid. Anti-arthritic and anti-inflammatory activities evaluated in vivo in different rodent models revealed that the ionic liquid-based microemulsion is more effective in controlling inflammation than the oily solution, the oil-based microemulsion and the marketed formulation of etodolac $\left(\right.$ Proxym gel $\left.{ }^{\circledR}\right)$ [285].

\subsubsection{Local Anesthetic Activity}

Negi et al. prepared nanoemulsions for the enhanced percutaneous absorption of lidocaine and prilocaine [286]. Nanoemulsions were prepared using a high-shear mixing followed by the high-pressure homogenization, had droplet size of around $100 \mathrm{~nm}$ and almost neutral zeta potential. The permeation rates and permeability coefficient values of the drugs from the optimized nanoemulsion systems were significantly higher than those from the marketed cream. The nanoemulsions were further incorporated into carbopol hydrogel, which decreased the skin permeability of the drugs, because of the higher vehicle viscosity. The nanoemulsions and the nanoemulsion gel formulations had a significantly stronger anesthetic effect in vivo compared with the marked formulation at the same concentrations of the drugs; a quicker onset of action, and a prolonged duration of anesthetic effect as compared to the marketed formulation.

\subsubsection{Antifungal Activity}

Coneac et al. developed microemulsion-loaded hydrogels for the topical delivery of fluconazole [287]. Microemulsions were stabilized by nonionic surfactants, and had average droplet sizes between 4 and $5 \mathrm{~nm}$, while the drug molecules were mainly located at the oil-water interface. The optimized microemulsions were incorporated in carbopol gels and showed higher flux values and higher release rate in vitro in comparison with a conventional hydrogel. These optimized microemulsion-loaded hydrogels also exhibited similar or slightly higher in vitro antifungal activity against candida albicans as compared to that of the conventional hydrogel and Nizoral ${ }^{\circledR}$ cream, respectively.

\subsubsection{Antioxidant Activity}

Lv et al. employed essential oil-based microemulsions to improve the solubility, $\mathrm{pH}$ stability, photostability, and skin permeation of quercetin for topical application [288]. The droplet size of the resultant microemulsions depended on the surfactant mix/ essential oil ratio but was under $100 \mathrm{~nm}$ for all measured ratios. In this study, the self-microemulsifying drug delivery systems (SMEDDs) were first prepared and then formed microemulsions 
when diluted 20 times by deionized water. The droplet size of the selected microemulsions was below $20 \mathrm{~nm}$. The solubility of quercetin was superior in the SMEDDs compared with the pure oil, and it was significantly higher in the microemulsions compared with water. In addition, the microemulsions protected quercetin to a certain extent from degradation in alkaline environment and under UV radiation. Also, the in vitro skin permeation study on rat skin revealed that the essential oil-based microemulsions could enhance the permeation capacity of quercetin by 2.5-3 times compared with the aqueous solution.

\subsubsection{Antipsoriatic Activity}

Kaur et al. reported on the development and optimization of clobetasol propionateand calcipotriol- loaded nanoemulsion gel for the topical treatment of psoriasis [289]. Nanoemulsions were formed by the spontaneous emulsification method. Carbopol 980 was used as a gelling agent to achieve the final drug concentration of $0.05 \%$ wt and $0.005 \%$ wt respectively for clobetasol propionate and calcipotriol. Keratinocyte cell lines showed higher uptake of the drugs from the nanoemulsion, and the penetration of both drugs from the nanoemulsion and gel formulations into the skin (SC and viable layers) was increased. Nanoemulsion-containing gel also demonstrated a significantly higher antipsoriatic activity in the imiquimod-induced psoriasis model in mice compared with the free drugs and a marketed formulation [289]. Rajitha et al. prepared methotrexate loaded nanoemulsion based on chaulmoogra oil [290]. Self emulsification method was employed and the resultant nanoemulsion had an average droplet size of around $35 \mathrm{~nm}$, was strongly negatively charged, and had skin-compatible acidity levels. The ex vivo skin permeation using porcine skin indicated the enhanced permeation and retention of the drug in the deep skin layers when compared with methotrexate solution. The in vivo anti-psoriatic studies were done in the imiquimod psoriatic mice model and revealed the superior anti-psoriatic efficacy and the effective drug retention in the skin [290].

\subsubsection{Anticarcinogenic Activity}

Pham et al. developed a scalable, low-energy nano-emulsification approach for optimized incorporation of Tocomin ${ }^{\circledR}$, tocotrienols-rich palm oil possessing anti-cancer activity, for adjunctive therapy of skin carcinomas [291]. Tocomin ${ }^{\circledR}$ - loaded nanoemulsions were obtained by different preparation methods. The hybrid nano-emulsification technique of single-phase inversion temperature homogenization cycle followed by a reduced ultrasonication produced stable Tocomin ${ }^{\circledR}$-loaded nanoemulsion. This system demonstrated a superior cytotoxic profile against two human cutaneous carcinoma cell models compared with Tocomin ${ }^{\circledR}$-in propyleneglycol admixture.

\subsection{Transdermal Delivery with Microemulsions and Nanoemulsions}

Wang et al. developed ionic liquid-in-water microemulsion for transdermal delivery of the hydrophilic hemostatic agent, dencichine [292]. The microemulsion had an average droplet size of $48 \mathrm{~nm}$, a negative zeta potential of $-15 \mathrm{mV}$, and it enhanced the in vitro skin permeation of dencichine approximately 10-fold compared with the drug solution in water. The pharmacodynamic evaluation performed in rats in vivo indicated a significant hemostatic activity after the application of dencichine loaded microemulsion. In [292] El-Leithy et al. investigated nanoemulsions for transdermal delivery of indomethacin [293]. Most of the evaluated systems had average droplet sizes between 40 and $131 \mathrm{~nm}$ and showed flux values between 5.79 and $55.81 \mathrm{mg} / \mathrm{cm}^{2} / \mathrm{h}$. Pharmacokinetics studies in rats in vivo demonstrated that nanoemulsion formulae and the commercial indomethacin topical gel containing alcohol (Farcomethacin ${ }^{\circledR}$ ) resulted in similar levels of indomethacin in plasma. This was attributed to the permeation enhancement effect of alcohol [293].

Table 3 summarizes additional advances in cutaneous drug delivery systems based on nanoemulsions and microemulsions. 
Table 3. Recent studies on dermal/transdermal drug delivery systems comprising nanoemulsions and microemulsions.

\begin{tabular}{|c|c|c|c|}
\hline $\begin{array}{l}\text { Type of Emulsion System } \\
\text { (Microemulsion/Nanoemulsion) }\end{array}$ & Drug/Active Material & Purpose & Reference \\
\hline Nanoemulsion & Oleanolic and ursolic acid & $\begin{array}{l}\text { Design a nanoemulsion system } \\
\text { containing oleanolic and ursolic acid } \\
\text { of dermal controlled release for } \\
\text { anti-inflammatory activity }\end{array}$ & [284] \\
\hline Nanoemulsion & Lidocaine and pirlocaine & $\begin{array}{l}\text { Design of lidocaine and prilocaine } \\
\text { loaded nanoemulsion for enhanced } \\
\text { percutaneous absorption for } \\
\text { local anesthetics }\end{array}$ & [286] \\
\hline Nanoemulsion & Ferulic acid & $\begin{array}{c}\text { Design of ferulic acid loaded } \\
\text { nanoemulsion against UVA mediated } \\
\text { oxidative stress }\end{array}$ & [294] \\
\hline Nanoemulsion & Curcumin & $\begin{array}{l}\text { Formulation of curcumin loaded } \\
\text { nanoemulsion for effect in } \\
\text { inflammatory arthritis disorders }\end{array}$ & [295] \\
\hline Nanoemulsion & Indomethacin & $\begin{array}{l}\text { Development of indomethacin loaded } \\
\text { nanoemulsion for transdermal } \\
\text { delivery for increasing plasma levels }\end{array}$ & [293] \\
\hline Microemulsion & Etodolac & $\begin{array}{c}\text { Development of an ionic liquid-in } \\
\text { water microemulsion containing } \\
\text { etodolac for } \\
\text { anti-inflammatory treatments }\end{array}$ & [285] \\
\hline Microemulsion & Fluconazole & $\begin{array}{l}\text { Design of fluconazole loaded } \\
\text { microemulsion for } \\
\text { antifungal activities }\end{array}$ & [287] \\
\hline Microemulsion & Itraconazole & $\begin{array}{c}\text { Formulation of microemulsion } \\
\text { containing itraconazole for antifungal } \\
\text { efficacy against a standardized tinea } \\
\text { pedis infection }\end{array}$ & [296] \\
\hline Microemulsion & Pseudolaric acid B & $\begin{array}{l}\text { Formulation of pseudolaric acid B } \\
\text { loaded microemulsion for antifungal } \\
\text { activity against azole-resistant } \\
\text { candida species }\end{array}$ & [297] \\
\hline Microemulsion & Fusidic acid & $\begin{array}{l}\text { Development of fusidic acid loaded } \\
\text { biocompatible microemulsion for } \\
\text { eradicating methicillin-sensitive } \\
\text { staphylococcus aureus } \\
\text { bacterial infections }\end{array}$ & [298] \\
\hline Microemulsion & Bleomycin, cisplatin and ifosfamide & $\begin{array}{l}\text { Formulation of microemulsion } \\
\text { containing bleomycin, cisplatin, and } \\
\text { ifosfamide for anti-tumor activities }\end{array}$ & [299] \\
\hline Microemulsion & $\begin{array}{l}\text { Diethylenetriaminepentaacetic acid } \\
\text { calcium trisodium salt hydrate }\end{array}$ & $\begin{array}{c}\text { Development of } \\
\text { diethylenetriaminepentaacetic acid } \\
\text { calcium trisodium salt hydrate } \\
\text { loaded microemulsion for } \\
\text { decorporation applications }\end{array}$ & [300] \\
\hline Microemulsion & Resveratrol & $\begin{array}{l}\text { Design of microemulsion containing } \\
\text { resveratrol to protect skin against } \\
\text { UV-induced damage }\end{array}$ & [301] \\
\hline Nanoemulsion & Amphotericin B & $\begin{array}{c}\text { Design of amphotericin B loaded } \\
\text { nanoemulsions for } \\
\text { antifungal treatments }\end{array}$ & [302] \\
\hline
\end{tabular}


Table 3. Cont.

\begin{tabular}{|c|c|c|c|}
\hline $\begin{array}{l}\text { Type of Emulsion System } \\
\text { (Microemulsion/Nanoemulsion) }\end{array}$ & Drug/Active Material & Purpose & Reference \\
\hline Nanoemulsion & Benzyl benzoate & $\begin{array}{c}\text { Formulation of benzyl benzoate } \\
\text { loaded nanoemulsion for treatment } \\
\text { of scabies }\end{array}$ & [303] \\
\hline Nanoemulsion & Ketoconazole & $\begin{array}{l}\text { Preparation of ketoconazole loaded } \\
\text { nanoemulsion converted into } \\
\text { nanoemulgel for effective } \\
\text { management of onychomycosis }\end{array}$ & [304] \\
\hline Nanoemulsion & $\begin{array}{l}\text { Triterpenoids isolated from } \\
\text { ganoderma lucidum }\end{array}$ & $\begin{array}{l}\text { Formulation of triterpenoids loaded } \\
\text { nanoemulsion for frostbite treatment }\end{array}$ & [305] \\
\hline Nanoemulsion & Isotretinoin & $\begin{array}{l}\text { Design of isotretinoin loaded } \\
\text { nanoemulsion for acne treatments }\end{array}$ & [306] \\
\hline Nanoemulsion & Tocotrienol & $\begin{array}{l}\text { Formulation of nanoemulsions } \\
\text { containing tocotrienol for topical } \\
\text { delivery against skin carcinomas }\end{array}$ & [291] \\
\hline Microemulsion & Tazarotene & $\begin{array}{c}\text { Formulation of tazarotene loaded } \\
\text { microemulsion for treatments } \\
\text { of psoriasis }\end{array}$ & [307] \\
\hline Microemulsion & Pentoxifylline & $\begin{array}{l}\text { Developing of microemulsion } \\
\text { containing pentoxifylline for } \\
\text { anti-inflammatory activity }\end{array}$ & [308] \\
\hline Microemulsion & Methotrexate & $\begin{array}{c}\text { Preparation of methotrexate loaded } \\
\text { microemulsion for } \\
\text { psoriasis treatments }\end{array}$ & [309] \\
\hline Microemulsion & Ibuprofen & $\begin{array}{c}\text { Formulation of ibuprofen loaded } \\
\text { microemulsion for } \\
\text { anti-inflammatory activity }\end{array}$ & [310] \\
\hline Microemulsion & Sertaconazole & $\begin{array}{l}\text { Development of sertaconazole loaded } \\
\text { microemulsion for antifungal } \\
\text { treatments against candida albicans }\end{array}$ & [311] \\
\hline Microemulsion & Imiquimod & $\begin{array}{l}\text { Development of microemulsion } \\
\text { containing imiquimod for the } \\
\text { treatment of neoplastic skin diseases }\end{array}$ & [312] \\
\hline Nanoemulsion & $\begin{array}{l}\text { Clobitasol propionate } \\
\text { and calcipotriol }\end{array}$ & $\begin{array}{l}\text { Formulation of nanoemulsions } \\
\text { containing clobetasol propionate and } \\
\text { calcipotriol for treatments of psoriasis }\end{array}$ & [289] \\
\hline Nanoemulsion & Cyclosporine & $\begin{array}{c}\text { Preparation of cyclosporine loaded } \\
\text { nanoemulsions for } \\
\text { psoriasis treatments }\end{array}$ & [313] \\
\hline Nanoemulsion & Psoralen & $\begin{array}{c}\text { Preparation of psoralen loaded } \\
\text { nanoemulsion for psoriasis and } \\
\text { vitiligo treatments }\end{array}$ & [314] \\
\hline Nanoemulsion & Phenytoin & $\begin{array}{l}\text { Design of nanoemulsion containing } \\
\text { phenytoin for topical wound healing }\end{array}$ & [315] \\
\hline Nanoemulsion & Zinc phthalocyanine & $\begin{array}{c}\text { Development of zinc phthalocyanine } \\
\text { loaded nanoemulsion for use in } \\
\text { photodynamic therapy } \\
\text { for leishmaniasis }\end{array}$ & [316] \\
\hline Nanoemulsion & Phenylethyl resorcinol & $\begin{array}{l}\text { Formulation of phenylethyl } \\
\text { resorcinol loaded nanoemulsion for } \\
\text { skin lightening }\end{array}$ & [317] \\
\hline
\end{tabular}


Table 3. Cont.

\begin{tabular}{|c|c|c|c|}
\hline $\begin{array}{l}\text { Type of Emulsion System } \\
\text { (Microemulsion/Nanoemulsion) }\end{array}$ & Drug/Active Material & Purpose & Reference \\
\hline Microemulsion & Retinoid & $\begin{array}{c}\text { Formulation of retinoid loaded } \\
\text { microemulsion for } \\
\text { psoriasis treatments }\end{array}$ & [318] \\
\hline Microemulsion & Tacrolimus & $\begin{array}{c}\text { Preparation of tacrolimus loaded } \\
\text { microemulsion for } \\
\text { anti-psoriatic activity }\end{array}$ & [317] \\
\hline Microemulsion & Quercetin & $\begin{array}{l}\text { Preparation of microemulsion } \\
\text { containing quercetin as a } \\
\text { powerful antioxidant }\end{array}$ & [288] \\
\hline Microemulsion & Clotrimazole & $\begin{array}{l}\text { Formulation of microemulsion coated } \\
\text { with chitosan and containing } \\
\text { clotrimazole for antifungal activity }\end{array}$ & [319] \\
\hline Microemulsion & Griseofulvin & $\begin{array}{l}\text { Development of griseofulvin loaded } \\
\text { microemulsions for } \\
\text { antifungal treatments }\end{array}$ & [320] \\
\hline Nanoemulsion & Coenzyme Q10 & $\begin{array}{l}\text { Formulation of coenzyme Q10 loaded } \\
\text { nanoemulsion as an antioxidant agent }\end{array}$ & [321] \\
\hline Nanoemulsion & 8-Methoxypsoralen & $\begin{array}{l}\text { Formulation of 8-methoxypsoralen } \\
\text { loaded nanoemulsions for treatments } \\
\text { in vitiligo and psoriasis }\end{array}$ & [322] \\
\hline Nanoemulsion & Adapalene and tea tree oil & $\begin{array}{c}\text { Preparation of nanoemulsion } \\
\text { containing tea tree oil and adapalene } \\
\text { for antibacterial activity against } \\
\text { propionibacterium acnes }\end{array}$ & [323] \\
\hline Nanoemulsion & Rosmarinic acid & $\begin{array}{c}\text { Development of rosmarinic acid } \\
\text { loaded nanoemulsions for } \\
\text { antioxidant activity }\end{array}$ & [324] \\
\hline Nanoemulsion & Hydroxyethylcellulose & $\begin{array}{l}\text { Preparation of nanoemulsions } \\
\text { containing hydroxyethylcellulose for } \\
\text { anti-herpes treatment }\end{array}$ & [325] \\
\hline Nanoemulsion & Heparinoid & $\begin{array}{l}\text { Development of heparinoid loaded } \\
\text { nanoemulsion for the treatment of } \\
\text { superficial thrombophlebitis }\end{array}$ & [326] \\
\hline Microemulsion & Diclofenac sodium & $\begin{array}{l}\text { Formulation of diclofenac sodium } \\
\text { loaded microemulsion for } \\
\text { anti-inflammatory activity }\end{array}$ & [327] \\
\hline Microemulsion & 20(S)-protopanaxadiol & $\begin{array}{c}\text { Development of } \\
\text { 20(S)-protopanaxadiol loaded } \\
\text { microemulsion for anti-aging activity }\end{array}$ & [328] \\
\hline Microemulsion & Tetrapeptide PKEK & $\begin{array}{l}\text { Preparation of microemulsion } \\
\text { containing tetrapeptide PKEK for } \\
\text { reducing UVB induced effects }\end{array}$ & [329] \\
\hline Microemulsion & Astilbin & $\begin{array}{l}\text { Preparation of astilbin loaded } \\
\text { microemulsions for } \\
\text { anti-inflammatory activity }\end{array}$ & [330] \\
\hline Nanoemulsion & Capsaicin & $\begin{array}{l}\text { Formulation of nanoemulsion } \\
\text { containing capsaicin for } \\
\text { anti-inflammatory effects }\end{array}$ & {$[331]$} \\
\hline
\end{tabular}


Table 3. Cont.

\begin{tabular}{|c|c|c|c|}
\hline $\begin{array}{l}\text { Type of Emulsion System } \\
\text { (Microemulsion/Nanoemulsion) }\end{array}$ & Drug/Active Material & Purpose & Reference \\
\hline Nanoemulsion & $\begin{array}{l}\text { Chaulmoogra oil-based } \\
\text { methotrexate }\end{array}$ & $\begin{array}{l}\text { Formulation of chaulmoogra } \\
\text { oil-based methotrexate loaded } \\
\text { nanoemulsion for the treatment } \\
\text { of psoriasis }\end{array}$ & [290] \\
\hline Nanoemulsion & Thymol & $\begin{array}{c}\text { Preparation of thymol loaded } \\
\text { nanoemulsion for anti-acne } \\
\text { vulgaris treatments }\end{array}$ & [332] \\
\hline Nanoemulsion & $\begin{array}{l}\text { Daidzein, genistein, and glycitein } \\
\text { (from a soybean isoflavone) }\end{array}$ & $\begin{array}{l}\text { Formulation of daidzein, genistein, } \\
\text { and glycitein loaded nanoemulsion } \\
\text { for antioxidant activity }\end{array}$ & [333] \\
\hline Nanoemulsion & Mangiferin & $\begin{array}{l}\text { Formulation of mangiferin loaded } \\
\text { nanoemulsions for } \\
\text { anti-inflammatory treatments }\end{array}$ & [334] \\
\hline Nanoemulsion & Clove oil & $\begin{array}{l}\text { Development of nanoemulsion } \\
\text { containing clove oil for activities } \\
\text { against candida }\end{array}$ & [335] \\
\hline Nanoemulsion & Pomegranate seed oil & $\begin{array}{l}\text { Development of pomegranate seed } \\
\text { oil loaded nanoemulsions for } \\
\text { photo-protective purposes }\end{array}$ & [336] \\
\hline Microemulsion & 3,5, $4^{\prime}$-Trimethoxy-trans-stilbene & $\begin{array}{c}\text { Preparation of } \\
3,5,4^{\prime} \text {-trimethoxy-trans-stilbene } \\
\text { loaded microemulsion for treatment } \\
\text { of osteoarthritis }\end{array}$ & [337] \\
\hline Microemulsion & Betamethasone dipropionate & $\begin{array}{l}\text { Development of betamethasone } \\
\text { dipropionate loaded microemulsion } \\
\text { for anti-inflammatory effects }\end{array}$ & [337] \\
\hline Microemulsion & $\begin{array}{l}\text { Histidine capped silver } \\
\text { nanoparticles }\end{array}$ & $\begin{array}{l}\text { Formulation of microemulsions } \\
\text { containing histidine capped silver } \\
\text { nanoparticles for treatments of burn } \\
\text { wound infections }\end{array}$ & [338] \\
\hline Microemulsion & Resveratrol & $\begin{array}{c}\text { Design of microemulsions containing } \\
\text { resveratrol for chemoprevention of } \\
\text { skin cancer }\end{array}$ & [339] \\
\hline Microemulsion & 5-Fluorocuracil & $\begin{array}{l}\text { Formulation of microemulsions } \\
\text { containing 5-fluorouracil for skin } \\
\text { cancer treatments }\end{array}$ & [340] \\
\hline Microemulsion & Benzophenone-rich extract & $\begin{array}{l}\text { Preparation of benzophenone-rich } \\
\text { extract loaded microemulsion for } \\
\text { antifungal treatments }\end{array}$ & [341] \\
\hline Microemulsion & Retinyl palmitate & $\begin{array}{l}\text { Development of microemulsion } \\
\text { containing retinyl palmitate for } \\
\text { treatments of skin disorders such as } \\
\text { acne, aging, and psoriasis }\end{array}$ & [342] \\
\hline Microemulsion & Pioglitazone & $\begin{array}{l}\text { Preparation of microemulsion } \\
\text { containing pioglitazone for } \\
\text { anti-inflammatory treatments }\end{array}$ & [343] \\
\hline Nanoemulsion & Cyclosporine & $\begin{array}{c}\text { Formulation of cyclosporine loaded } \\
\text { nanoemulsion for treatments } \\
\text { of psoriasis }\end{array}$ & [344] \\
\hline
\end{tabular}


Table 3. Cont.

\begin{tabular}{|c|c|c|c|}
\hline $\begin{array}{l}\text { Type of Emulsion System } \\
\text { (Microemulsion/Nanoemulsion) }\end{array}$ & Drug/Active Material & Purpose & Reference \\
\hline Nanoemulsion & Ivermectin & $\begin{array}{l}\text { Development of nanoemulsions } \\
\text { containing ivermectin to treat } \\
\text { different types of parasite infestations }\end{array}$ & [345] \\
\hline Nanoemulsion & Vitamin $A+E$ & $\begin{array}{l}\text { Formulation of vitamin } \mathrm{E} \text { and } \mathrm{A} \\
\text { loaded nanoemulsion for the } \\
\text { treatment of acute skin inflammation }\end{array}$ & [346] \\
\hline Nanoemulsion & Phloretin & $\begin{array}{l}\text { Design of phloretin loaded } \\
\text { nanoemulsion for treatment } \\
\text { of vaginitis }\end{array}$ & [347] \\
\hline Nanoemulsion & $\begin{array}{l}\text { Retinyl palmitate and } \\
\text { dead seawater }\end{array}$ & $\begin{array}{c}\text { Preparation of retinyl palmitate and } \\
\text { dead sea water loaded } \\
\text { nanoemulsions for topical } \\
\text { anti-photoaging and } \\
\text { anti-inflammatory treatments }\end{array}$ & [348] \\
\hline Nanoemulsion & Triptolide & $\begin{array}{l}\text { Development of triptolide } \\
\text { nanoemulsion gels for percutaneous } \\
\text { administration for treatment of eczema }\end{array}$ & [349] \\
\hline Microemulsion & Triamcinolone & $\begin{array}{l}\text { Formulation of microemulsion } \\
\text { containing triamcinolone for } \\
\text { transdermal delivery for } \\
\text { eczema treatments }\end{array}$ & [350] \\
\hline Microemulsion & Nicotinamide & $\begin{array}{l}\text { Formulation of microemulsion based } \\
\text { gel of nicotinamide for acne and } \\
\text { cellulite treatments }\end{array}$ & {$[351]$} \\
\hline Nanoemulsion & Tretinoin & $\begin{array}{c}\text { Preparation of nanoemulsion system } \\
\text { for topical delivery of tretinoin for } \\
\text { effective anti-acne activity }\end{array}$ & [352] \\
\hline Microemulsion & $\begin{array}{l}\text { Indian penny wort, walnut, } \\
\text { and turmeric }\end{array}$ & $\begin{array}{l}\text { Formulation and clinical evaluation } \\
\text { of topical dosage microemulsion of } \\
\text { indian penny wort, walnut, and } \\
\text { turmeric for eczema treatments }\end{array}$ & [353] \\
\hline Nanoemulsion & Curcumin & $\begin{array}{c}\text { Formulation of curcumin loaded } \\
\text { nanoemulsion for transdermal } \\
\text { delivery for } \\
\text { anti-inflammatory treatments }\end{array}$ & {$[354]$} \\
\hline Nanoemulsion & $\begin{array}{l}\text { Foeniculum vulgare mill. } \\
\text { essential oil }\end{array}$ & $\begin{array}{c}\text { Formulation of foeniculum vulgare } \\
\text { mill. essential oil loaded } \\
\text { nanoemulsion for transdermal } \\
\text { delivery for antioxidant and } \\
\text { antidiabetic activities }\end{array}$ & [355] \\
\hline Microemulsion & Dencichine & $\begin{array}{l}\text { Formulation of dencichine loaded } \\
\text { microemulsion for transdermal } \\
\text { delivery for hemorrhage treatments }\end{array}$ & [292] \\
\hline Microemulsion & Methyl dihydrojasmonate & $\begin{array}{c}\text { Formulation of methyl } \\
\text { dihydrojasmonate loaded } \\
\text { microemulsion for transdermal } \\
\text { delivery for anti-tumor activity }\end{array}$ & [356] \\
\hline Microemulsion & Boswellia carterii oleo-gum-resin & $\begin{array}{l}\text { Preparation of boswellia carterii } \\
\text { oleo-gum resin loaded microemulsion } \\
\text { for the treatment of inflammatory } \\
\text { dermatological diseases, such as acne } \\
\text { and eczema }\end{array}$ & [357] \\
\hline
\end{tabular}




\section{Polymeric Nanoparticles}

Polymeric nanoparticles are widely employed in many areas of drug delivery [358-368], while in dermal applications they typically prolong the residence time of active materials in the $S C$ and other upper layers of the skin. These particles localize in the follicular openings in a time- and size-dependent manner and can efficiently liberate their active cargo there, enhancing skin distribution and permeability of the active material [369]. Depending on their inner structure and the content, polymeric nanoparticles may be further classified as nanospheres or nanocapsules [370]. Polymeric nanospheres are typically composed of a solid polymeric matrix, while polymeric nanocapsules contain a liquid/solid core coated with a polymeric shell or just a polymeric shell filled with a drug [371,372]. These morphology variations of polymeric nanoparticles lead to different entrapment mechanisms, while drugs can be either encapsulated in nanocapsules or dispersed in the polymeric matrix of nanospheres (Figure 9) [372-374].

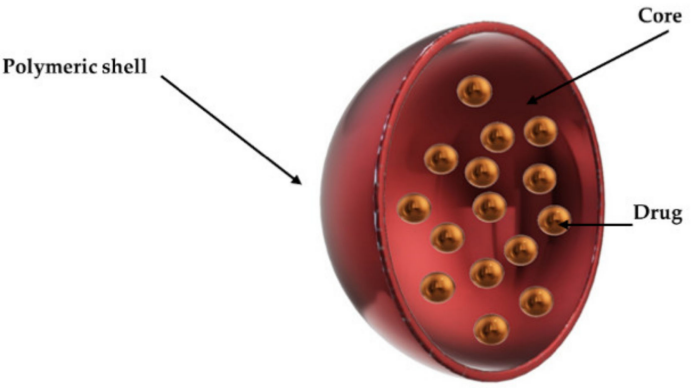

(a)

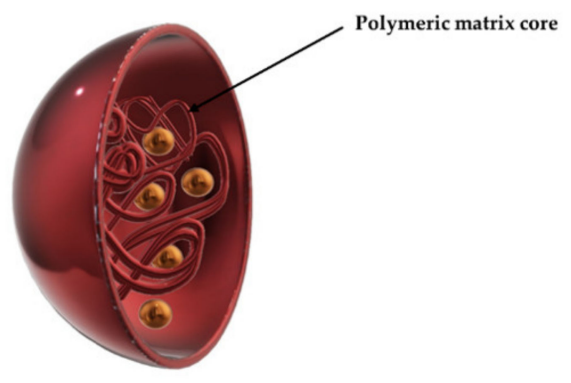

(b)

Figure 9. Schematic illustration of (a) nanocapsules, (b) nanospheres.

Due to their outer solid structure, polymeric nanoparticles may provide additional advantages in cutaneous application besides prolonging the residence time of the active material in the skin. Thus, they can control the rate and the extent of drug release and also protect drugs from degradation upon exposure to the external environment on the skin surface $[375,376]$. Various types of polymers, natural and synthetic, biodegradable and nonbiodegradable, can be employed to prepare polymeric nanoparticles [377]. These polymers include chitosan, alginate, gelatin (natural), aliphatic polyesters, poly( $\varepsilon$-caprolactone), poly(lactide-co-glycolide) (biodegradable), and polyacrylates, poly (methyl methacrylate) (nonbiodegradable) $[378,379]$. Different methods are being employed to produce polymeric nanoparticles. These methods use two main strategies:(1) in situ polymerization, (2) precipitation of pre-formed polymers [371,372,380,381]. In many preparation techniques an organic solvent is required to dissolve the polymer and the active substance, and it can be subsequently removed to avoid toxicity [382].

Some recent works that describe employing polymeric nanoparticles in dermal drug delivery systems are highlighted below.

\subsection{Topical Delivery with Polymeric Nanoparticles}

\subsubsection{Anti-inflammatory Activity}

Mathes et al. investigated three types of polymeric nanocarriers (nanospheres, nanocapsules, and lipid-core nanocapsules) with average sizes between 100 and $260 \mathrm{~nm}$ and slightly negative zeta potential for the delivery of potent glucocorticoid, clobetasol propionate, to treat inflammatory-based scalp diseases by a sustained release of the drug into hair follicles [383]. The three types of nanoparticles were prepared by the nanoprecipitation-solvent evaporation technique using poly( $\varepsilon$-caprolactone) and showed a successful encapsulation of clobetasol propionate. They all demonstrated sustained-release characteristics, reduced permeation across the skin, and achieved a differential accumulation in hair follicles, while nanocapsules had the highest follicular recovery. This could be because of the more flexible 
core-shell structure of nanocapsules compared with the rigid matrix of nanospheres, and the reduced stiffness of the former compared with the lipid-core nanocapsules.

\subsubsection{Antiviral Activity}

Donalisio et al., developed acyclovir loaded chitosan nanospheres for the topical treatment of herpes simplex virus [384]. Chitosan nanospheres were prepared from $\mathrm{W} / \mathrm{O}$ nanoemulsion and had an average size of about $200 \mathrm{~nm}$, with a strongly positive zeta potential $(\sim+40 \mathrm{mV})$. The loading capacity of the drug was around $8.5 \%$ with an encapsulation efficiency of about $87 \%$. The in vitro permeation study showed the enhancement of acyclovir permeation through the skin when delivered by the chitosan nanosphere gel compared with a commercial cream formulation. The acyclovir-loaded chitosan nanospheres also showed higher antiviral activity compared to that of the free drug against both the HSV-1 and the HSV-2 virus strains.

\subsubsection{Alopecia Treatment}

Roque et al., employed poly(lactic-co-glycolic acid) nanoparticles for topical delivery of finasteride, a potent anti-alopecia agent [385]. Finasteride has a beneficial effect on hair regrowth; however, it may cause severe side effects when taken orally. The polymeric nanoparticles were prepared by a modified emulsification/solvent diffusion method and had an average size of $300 \mathrm{~nm}$, which is suitable for the delivery into hair follicles, and very slightly negative zeta potential. High encapsulation efficiency was achieved for hydrophilic finasteride $(\sim 80 \%)$, which suggested a possible interaction between poly(lactic-co-glycolic acid) and the drug. Scanning electron microscope images showed that the nanoparticles had a spherical shape and a smooth surface. In vitro release studies in physiological conditions indicated that the nanoparticles led to a prolonged release of finasteride for $3 \mathrm{~h}$. Safety testing of the excipients using human volunteers indicated that the formulation excipients were compatible with the skin.

Additional recent works on employing polymeric nanoparticles in dermal drug delivery systems are summarized in Table 4.

Table 4. Recent studies on dermal drug delivery systems comprising polymeric nanocapsules/ nanospheres/ microspheres.

\begin{tabular}{|c|c|c|c|}
\hline $\begin{array}{l}\text { Type of Polymeric Nanosystem } \\
\text { (Nanoparticles/Spheres/Capsuls) }\end{array}$ & Drug/Active Material & Purpose & Reference \\
\hline Nanoparticles & Curcumin & $\begin{array}{l}\text { Formulation of curcumin } \\
\text { encapsulated nanoparticles based on } \\
\text { silica/polyethylene glycol/ chitosan } \\
\text { as antimicrobial and wound } \\
\text { healing agent }\end{array}$ & [386] \\
\hline Nanoparticles & Selenium nanoparticles & $\begin{array}{l}\text { Preparation of selenium } \\
\text { nanoparticles stabilized by chitosan } \\
\text { for antioxidant activity }\end{array}$ & [387] \\
\hline Nanoparticles & Curcumin & $\begin{array}{l}\text { Formulation of curcumin loaded } \\
\text { polylactic-co-glycolic acid } \\
\text { nanoparticles in hydrogel for } \\
\text { anti-psoriatic treatments }\end{array}$ & [388] \\
\hline Nanoparticles & $7,3^{\prime}, 4^{\prime}$-Trihydroxyisoflavone & $\begin{array}{l}\text { Design of acid-responsive polymeric } \\
\text { nanoparticles based on polyvinyl } \\
\text { alcohol for } \\
7,3^{\prime}, 4^{\prime} \text {-trihydroxyisoflavone topical } \\
\text { administration as antioxidant and } \\
\text { melanin inhibitor }\end{array}$ & [389] \\
\hline Nanoparticles & Porphyrin & $\begin{array}{l}\text { Development of hydrogels containing } \\
\text { porphyrin loaded nanoparticles based } \\
\text { on polylactic-co-glycolic acid for } \\
\text { topical photodynamic applications }\end{array}$ & [390] \\
\hline
\end{tabular}


Table 4. Cont.

\begin{tabular}{|c|c|c|c|}
\hline $\begin{array}{l}\text { Type of Polymeric Nanosystem } \\
\text { (Nanoparticles/Spheres/Capsuls) }\end{array}$ & Drug/Active Material & Purpose & Reference \\
\hline Nanoparticles & Finasteride & $\begin{array}{l}\text { Design of finasteride loaded } \\
\text { nanoparticles based on } \\
\text { polylactic-co-glycolic acid for the } \\
\text { potential treatment of alopecia }\end{array}$ & [385] \\
\hline Nanoparticles & Corticosteroids & $\begin{array}{l}\text { Development of corticosteroids } \\
\text { loaded nanoparticles based on } \\
\text { eudragit RS for controlled delivery in } \\
\text { corneal epithelium treatments. }\end{array}$ & [391] \\
\hline Nanoparticles & Betamethasone & $\begin{array}{c}\text { Formulation of polymeric } \\
\text { nanoparticles based on } \\
\text { poly- } \varepsilon \text {-caprolactone as the polymeric } \\
\text { core modified with fatty acids } \\
\text { encapsulating betamethasone for } \\
\text { inflammation treatment }\end{array}$ & [392] \\
\hline Nanoparticles & Betamethasone & $\begin{array}{l}\text { Formulation of betamethasone loaded } \\
\text { nanoparticles based on chitosan and } \\
\text { modified with hyaluronic acid for } \\
\text { anti-atopic dermatitis efficacy }\end{array}$ & [393] \\
\hline Nanoparticles & Dexamethasone & $\begin{array}{c}\text { Formulation of dexamethasone } \\
\text { loaded pH-sensitive polymeric } \\
\text { nanoparticles based on different } \\
\text { types of eudragit, } \\
\text { hydroxypropyl methylcellulose } \\
\text { phthalate } \\
\text { and cellulose acetate phthalate for } \\
\text { anti-inflammatory activity }\end{array}$ & [394] \\
\hline Nanoparticles & Fluorescent marker & $\begin{array}{c}\text { Preparation of polylactic acid } \\
\text { nanoparticles as anti-inflammatory } \\
\text { drug vehicle }\end{array}$ & [395] \\
\hline Nanoparticles & Elvitegravir & $\begin{array}{c}\text { Preparation of polylactic acid } \\
\text { hyperbranched polyglycerols } \\
\text { nanoparticles loaded with the } \\
\text { antiretroviral elvitegravir against } \\
\text { viral sexually transmitted diseases } \\
\text { such as human immunodeficiency } \\
\text { virus (HIV) }\end{array}$ & [396] \\
\hline Nanocapsules & Acetazolamide & $\begin{array}{c}\text { Design of novel polymeric } \\
\text { nanoparticles based on } \\
\text { polyethylcellulose and eudragit } \\
\text { RS100 for ophthalmic administration } \\
\text { of acetazolamide }\end{array}$ & [397] \\
\hline Nanoparticles & Benzocaine & $\begin{array}{l}\text { Formulation of benzocaine loaded } \\
\text { poly- } \varepsilon \text {-caprolactone nanoparticles } \\
\text { incorporated into poloxamer } 407 \\
\text { based hydrogel for topical pain relief }\end{array}$ & [398] \\
\hline Nanocapsules & Imatinib mesylate & $\begin{array}{c}\text { Formulation of layer-by-layer } \\
\text { polyethylene imine branched and } \\
\text { polystyrenesulfonate coated gold } \\
\text { nanoparticles for topicaldelivery of } \\
\text { imatinib mesylate to treat melanoma }\end{array}$ & [384] \\
\hline
\end{tabular}


Table 4. Cont.

\section{Type of Polymeric Nanosystem \\ (Nanoparticles/Spheres/Capsuls)}

Nanocapsules

Imiquimod

$\alpha$-tocopherol

Nanocapsules

Silibinin

Nanocapsules

Neutrophil elastase inhibitor

Tea tree oil

Nanocapsules

Triptolide

Nanocapsules

Phenytoin

Cyclosporin

Nanocapsules
Dexamethasone
Essential oil of R. officinalis and

L. dentata
Purpose

Reference

Formulation of chitosan as a cationic coating or gel vehicle for polymeric nanocapsules containing imiquimod

for enhancing the penetration in vaginal tissue

Design of $\alpha$-tocopherol loaded chitosan oleate nanoemulsion for wound healing treatments

Preparation of hydrogel containing silibinin and pomegranate oil loaded nanocapsules based on polyethylcellulose exhibiting anti-inflammatory effects on skin damage UVB radiation

Preparation of starch nanocapsules containing a novel neutrophil elastase inhibitor with an improved pharmaceutical performance for psoriasis treatments

Development of topical delivery of ebselen encapsulated in biopolymeric nanocapsules based on alginate for antifungal activity

Design of nanoemulsions of tea tree oil and nanocapsules based on polycaprolactone which provide anti-edematogenic effect and improved skin wound healing

ormulation of chloramphenicol and essential oil loaded

poly( $\varepsilon$-caprolactone)-pluronic nanocapsules for MRSA candida

co-infected chronic burn wound treatments

Preparation of chitosan nanocapsules containing phenytoin for wound healing activity

Formulation of solvent-free protamine nanocapsules as carriers for cyclosporin for anti-inflammatory activity

Formulation of cationic polymeric nanocapsules based on eudragit RS 100 for delivery of dexamethasone for the treatment of inflammatory and allergic skin disorders

Preparation of rosmarinus officinalis

L. and lavandula dentata essential

oils encapsulated in polymeric nanocapsules based on eudragit EPO 
Table 4. Cont.

\begin{tabular}{|c|c|c|c|}
\hline $\begin{array}{l}\text { Type of Polymeric Nanosystem } \\
\text { (Nanoparticles/Spheres/Capsuls) }\end{array}$ & Drug/Active Material & Purpose & Reference \\
\hline Nanocapsules & Latanoprost & $\begin{array}{l}\text { Latanoprost loaded polymeric } \\
\text { nanocapsules based on } \\
\text { poly- } \varepsilon \text {-caprolactone for effective } \\
\text { topical treatment of alopecia. }\end{array}$ & [410] \\
\hline Nanocapsules & 5-Fluorouracil & $\begin{array}{l}\text { Preparation of topical formulations } \\
\text { containing aptamer-functionalized } \\
\text { nanocapsules based on chitosan and } \\
\text { polyvinylpyrrolidone-alt-itaconic } \\
\text { anhydride poly copolymer for } \\
\text { encapsulation of 5-fluorouracil for } \\
\text { skin cancer therapy }\end{array}$ & [411] \\
\hline Nanocapsules & Clobetasol & $\begin{array}{l}\text { Formulation of nanocapsules based } \\
\text { on poly- } \epsilon \text {-caprolactone for } \\
\text { optimizing the balance between } \\
\text { interfollicular permeation and } \\
\text { follicular uptake of topically applied } \\
\text { clobetasol for anti-inflammatory } \\
\text { scalp diseases }\end{array}$ & [383] \\
\hline Nanospheres & Vitamin D3 & $\begin{array}{c}\text { Formulation of polymeric } \\
\text { nanospheres based on tryospheres } \\
\text { (copolymers with hydrophobic blocks } \\
\text { of oligomers of desaminotyrosyl } \\
\text { tyrosine esters and diacids and } \\
\text { hydrophilic blocks of poly(ethylene } \\
\text { glycol)) encapsulating vitamin D3 for } \\
\text { treatment of several skin disorders } \\
\text { including psoriasis }\end{array}$ & [412] \\
\hline Nanospheres & Acyclovir & $\begin{array}{l}\text { Development of acyclovir loaded } \\
\text { chitosan nanospheres for topical } \\
\text { treatment of herpes virus infections }\end{array}$ & [413] \\
\hline Nanocapsules & Itraconazole & $\begin{array}{l}\text { Development of itraconazole loaded } \\
\text { nanocapsules based } \\
\text { on polycaprolactone }\end{array}$ & [414] \\
\hline Nanocapsules & Cyclosporine & $\begin{array}{l}\text { Formulation of topical nanocapsules } \\
\text { based on polylactic-co-glycolic acid } \\
\text { encapsulating cyclosporine for atopic } \\
\text { dermatitis treatment }\end{array}$ & [415] \\
\hline Nanospheres & Erianin & $\begin{array}{l}\text { Development of erianin loaded } \\
\text { dendritic mesoporous silica } \\
\text { nanospheres with pro-apoptotic } \\
\text { effects and enhanced topical delivery } \\
\text { for psoriasis treatments }\end{array}$ & [416] \\
\hline Nanospheres & Rapamycin & $\begin{array}{l}\text { Formulation of rapamycin loaded } \\
\text { nanospheres based on } \\
\text { polylactic-co-glycolic acid for } \\
\text { anti-glioma treatment }\end{array}$ & [417] \\
\hline Nanospheres & Hyperforin & $\begin{array}{l}\text { Development of hyperforin loaded } \\
\text { nanospheres based on acetylated } \\
\text { dextran for anti-inflammatory activity }\end{array}$ & [418] \\
\hline Nanocapsules & Amphotericin B & $\begin{array}{c}\text { Formulation of nanocapsules based } \\
\text { on poly- } \varepsilon \text {-caprolactone encapsulating } \\
\text { amphotericin B for } \\
\text { antifungal treatments }\end{array}$ & [419] \\
\hline
\end{tabular}


Table 4. Cont.

\begin{tabular}{|c|c|c|c|}
\hline $\begin{array}{l}\text { Type of Polymeric Nanosystem } \\
\text { (Nanoparticles/Spheres/Capsuls) }\end{array}$ & Drug/Active Material & Purpose & Reference \\
\hline Nanocapsules & Ciprofloxacin & $\begin{array}{l}\text { Formulation of nanocapsules based } \\
\text { on polylactic-co-glycolic } \\
\text { acid-containing ciprofloxacin for } \\
\text { antibiotic treatments }\end{array}$ & [420] \\
\hline Nanocapsules & Curcumin & $\begin{array}{l}\text { Development of curcumin loaded } \\
\text { polylactic-co-glycolic acid-based } \\
\text { nanocapsules for enhanced solubility } \\
\text { and antibacterial activity }\end{array}$ & [421] \\
\hline Nanocapsules & Curcumin & $\begin{array}{l}\text { Formulation of curcumin loaded } \\
\text { nanocapsules based on polyethylene } \\
\text { glycol-polypropylene } \\
\text { glycol-polyethylene glycol for } \\
\text { anti-cancer activity }\end{array}$ & [422] \\
\hline Nanocapsules & Paclitaxel & $\begin{array}{l}\text { Development of paclitaxel loaded } \\
\text { nanocapsules based on } \\
\text { polylactic-co-glycolic } \\
\text { acid-polyethylene glycol for } \\
\text { cancer therapy }\end{array}$ & [423] \\
\hline Nanocapsules & $\begin{array}{c}\text { Cymbopogon martini } \\
\text { Roxburgh (Palmarosa oil) }\end{array}$ & $\begin{array}{l}\text { Development of cymbopogon martini } \\
\text { roxburgh (palmarosa oil) loaded } \\
\text { nanocapsules based on } \\
\text { polycaprolactone for } \\
\text { antioxidant/antimicrobial activity }\end{array}$ & [424] \\
\hline Nanocapsules & $\begin{array}{l}\text { Thymus vulgaris L. } \\
\text { (Thyme oil) } \\
\text { Roxburgh (Palmarosa oil) }\end{array}$ & $\begin{array}{c}\text { Formulation of thymus vulgaris L. } \\
\text { loaded nanocapsules based on } \\
\text { eudragit L100-55 for } \\
\text { antioxidant activity }\end{array}$ & [425] \\
\hline Nanocapsules & $\begin{array}{l}\text { Citrus bergamia Risso. } \\
\text { (Bergamot oil) and Citrus sinensis L. } \\
\text { (Orange oil) }\end{array}$ & $\begin{array}{c}\text { Formulation of citrus bergamia risso. } \\
\text { and citrus sinensis L. loaded } \\
\text { nanocapsules based on eudragit } \\
\text { L100-55 for antimicrobial activity }\end{array}$ & [426] \\
\hline Nanoparticles & Adapalene & $\begin{array}{l}\text { Development and characterization of } \\
\text { adapalene containing polymeric } \\
\text { nanoparticles based on tryospheres } \\
\text { for topical acne therapy }\end{array}$ & [427] \\
\hline Nanospheres & Adapalene & $\begin{array}{l}\text { Formulation of adapalene loaded } \\
\text { biodegradable nanospheres based on } \\
\text { poly( } \varepsilon \text {-caprolactone }) \text { for topical } \\
\text { treatment of acne }\end{array}$ & [428] \\
\hline Micro-nanocapsules & Retinyl palmitate & $\begin{array}{c}\text { Development of micro/nanocapsules } \\
\text { based on pectin polymer containing } \\
\text { retinyl palmitate for } \\
\text { anti-aging activity }\end{array}$ & [429] \\
\hline Nanocapsules & Flufenamic acid & $\begin{array}{l}\text { Development of flufenamic acid } \\
\text { loaded nanocapsules based on } \\
\text { polylactic-co-glycolic acid for } \\
\text { anti-inflammatory treatments }\end{array}$ & [430] \\
\hline
\end{tabular}

\section{Nanomaterials in Cosmetics and Skincare}

Although skincare has been in practice since the time of Ancient Egypt 6000 years ago [431] only recently the Food and Drug Administration (FDA) officially described cosmetics as "articles intended to be applied to the human body or any part thereof for 
cleansing, beautifying, promoting attractiveness, or altering the appearance" [384]. The FDA does not have the legal duty to approve skincare products before they are released to the market, however, these products must be safe for consumers and properly labelled [432]. The term "cosmeceutical" was coined to describe a cosmetic product comprising ingredients of potential bioactivity. Because of the aforementioned ability of nanomaterials to concentrate the active ingredients in the upper layers of the skin and increase their permeation, the performance-enhancing potential of nanometric formulations in cosmeceuticals is evident. However, due to the fact that the FDA is not involved in the testing or approving of these nanoformulations, there are substantial concerns among consumers pertaining to their safety. The most frequently raised concern is the risk of systemic absorption of nanoparticles from cosmetic products, for example of mineral nanoparticles from sunscreen creams. Various studies have extensively looked into this possibility and showed that mineral nanoparticles do not penetrate deeper than the epidermis. For instance, Lekki et al. have investigated the ability of titanium oxide nanoparticles with an average size of $20 \mathrm{~nm}$ to penetrate the skin, and it was found that the nanoparticles were present only in the 3-5 uppermost layers of the SC and in the hair follicles [433]. Similarly Menzel et al. investigated skin permeation of titanium oxide nanoparticles with an average size between $45 \mathrm{~nm}$ and $150 \mathrm{~nm}$ and found that the majority of the particles were retained on the skin surface and in the $S C$, with some penetration into the stratum granulosum, but with no presence in the stratum spinosum [434].

Despite these aforementioned concerns, a significant amount of research is being invested into the development of new cosmetic nanometric delivery systems for improved performance. In fact, all of the nanoparticle types discussed in the previous sections of this review are being widely investigated for applications in cosmetics [435-445]. Selected works showing the most recent advances in this field are detailed below.

\subsection{Applications in Skincare \\ 6.1.1. Moisturizers}

As discussed in the introduction, one of the most important roles of the $S C$ is to protect the body from dehydration by adjusting the transepidermal water loss (TEWL). Healthy skin water content is between 15 and 30\% in the SC, and around 70\% in the deeper skin layers. Reduction in this amount leads to dehydration, and, in extreme cases, to severe skin disorders. The main purpose of moisturizing creams is to decrease the TEWL and maintain skin hydration by blocking the openings on the skin surface with film-forming polymers as well as by promoting the permeation of natural moisturizing factors. These factors include ascorbyl palmitate, lactic acid, sodium lactate, natural oils, glycerol, urea, hyaluronic acid, and xanthan gum. For example, urea can form hydrophilic diffusion channels within the $S C$ to facilitate hydration [446]. Glycerol was shown to have a strong fluidizing effect on the corneodesmosomes [447]. Recently, hyaluronic acid has also gained popularity as a moisturizing agent owing to its ability to retain water more than 1000 times its weight. All these substances can be incorporated into nanoparticulate delivery systems to improve their SC accumulation and activity [448-457]. For instance, Ribeiro et al., investigated an $\mathrm{O} / \mathrm{W}$ nanoemulsion containing opuntia ficus-indica (L.) mill hydroglycolic extract, which is composed mainly of water and acts as a moisturizing factor and an anti-aging agent [458]. Nanoemulsion was able to increase the water content of the $S C$ for $5 \mathrm{~h}$ after application and was stable for at least 2 months.

\subsubsection{Anti-aging Creams}

Numerous external and internal factors, such as pollution, chemical products, UV radiation, and stress, are responsible for the aging process of the skin. This leads to the loss of elasticity and volume, as well as to the reduction in collagen and water content. The antiaging ingredients are intended to delay the aging process. For instance, retinoids are able to reduce wrinkles and lighten the dark spots by several mechanisms, including: (1) increasing the water content in the epidermis, (2) renewing the external cell layer, (3) boosting the 
synthesis of collagen, and (4) inhibiting matrix metalloproteinases responsible for collagen breakdown [432,459-461]. Despite these benefits, retinoids are highly irritant and their continuous application may lead to redness, local inflammation and peeling off the skin. In addition, these compounds are easily degradable by light and oxidation [462,463]. Hence, the incorporation of retinoids in nanocarriers can reduce skin irritation, prolong the duration of their action and prevent their degradation. As mentioned in previous sections of this review, various nanocarriers were developed for retinoid delivery. It is important to note that in the European Union retinoids can be employed in cosmetic applications below certain concentrations: up to $0.05 \%$ retinol equivalents for body lotions, and up to $0.3 \%$ for hand and face creams [464]. Another important ingredient of anti-aging products is Coenzyme Q10 (CoQ10), owing to its ability to reduce oxidative stress and scavenge free radicals. As we age, the amount of the CoQ10 in our body decreases; and this compound is challenging to replenish because it is basically insoluble in water and has poor cutaneous permeability. Therefore a suitable nanocarrier system can greatly improve the topical delivery of CoQ10 [465]. El-Leithy et al. developed O/W CoQ10-containing nanoemulsion, which showed an enhanced skin permeation ex vivo and led to an effective reduction in wrinkles in vivo, in rat models [466]. Other common antioxidants include $\alpha$-lipoic acid, vitamin $C$ and vitamin E. Vitamin E also has poor aqueous solubility and is highly sensitive to oxygen, light, and heat. Eiras et al. developed hydrogel-based vitamin E-loaded NLC and showed that the formulation is biocompatible and non-irritant [467].

\subsubsection{Anti-cellulite Creams}

Cellulite is an appearance of dimpled skin caused by structural changes in the subcutaneous adipose tissue [468-470]. Cellulite creams are topically applied directly to the affected areas aiming for the active agent to permeate into the skin and reduce the size of hypertrophic fat cells, as well as smoothen the appearance of the dimples on the skin surface [468,471-473]. Active ingredients that are able to reduce the appearance of cellulite include xanthines, retinoids, and lactic acid. Caffeine is a xanthine compound with a pronounced activity on lipolysis [474]. Touitou et al. in 1993 pioneered in the delivery of caffeine into and across the skin using liposomes and permeation enhancers respectively [475]. Recently, Hamishehkar et al. prepared caffeine-loaded SLN by the hot homogenization technique [476]. The SLN had a mean particle size of below $100 \mathrm{~nm}$, encapsulation efficiency of around $86 \%$, and loading efficiency of about $29 \%$ for the optimized formulation. The in vitro permeation studies demonstrated that caffeine-loaded SLN incorporated into carbopol hydrogel exhibited a significantly higher deposition of caffeine in the skin $(12 \%)$ compared with caffeine hydrogel $(0.75 \%)$, but had lower systemic adsorption. Histological studies revealed the complete lysis of adipocyte membrane in the hypodermis caused by the administration of caffeine-SLN-hydrogel, compared with the plain caffeine-loaded hydrogel, which had no effect on adipocytes lysis. Moreover, there was a significant reduction of fat tissue mass in the areas treated with caffeine loaded SLN after 1 and 3 weeks of treatment compared with the skin areas treated with the plain caffeine-loaded hydrogel or untreated skin (Figure 10).

\subsubsection{Sunscreens}

Sunlight is considered to be the best source of vitamin D and natural tanning. Ultraviolet A (UVA) radiation is responsible for skin tanning, while UVB provides the energy to produce vitamin D from cholesterol. However, extensive exposure to UV radiation harms the skin and stimulates aging, actinic keratosis, and the formation of free radicals that can lead to skin cancer $[477,478]$. Therefore, sunscreens are cosmetic products of utmost importance, capable of protecting the skin from these harmful effects. The most effective sunscreens today are mineral compounds based on zinc oxide $(\mathrm{ZnO})$ and titanium oxide $\left(\mathrm{TiO}_{2}\right)$. They form a physical screen on the skin that reflects the $\mathrm{UV}$ radiation and prevents it from penetrating to the deeper layers [479]. In addition, there are active substances such as benzophenone derivatives, vegetable oils, octyl methoxycinnamate, safranal, phenols, 
and others that can absorb and dissipate UV radiation [480]. There have been some recent concerns about the systemic hazards of frequent topical applications of classical chemical sunscreens, such as benzophenone derivatives or octyl methoxycinnamate. Benzophenone derivatives can be absorbed through the skin and exhibit estrogenic and antiandrogenic activities, while octyl-methoxycinnamate can photogenerate highly destructive reactive oxygen species in the skin [481]. In 2008 Touitou and Godin overcame these potential hazards by immobilization of UV-absorbing moieties in the jojoba oil chemical backbone to prevent their penetration [481]. Recently Badea et al. employed several vegetable oils to design NLC for the entrapment of a synthetic sunscreen compound, diethylamino hydroxybenzoyl hexyl benzoate (DHHB) [482]. These oils themselves served to provide broad-spectrum sun protection and antioxidant activity. The NLC were prepared by hot high-pressure homogenization and had a mean particle size between $100 \mathrm{~nm}$ and $145 \mathrm{~nm}$, and strongly negative zeta potential. The NLC showed enhanced photoprotective and antioxidant properties.

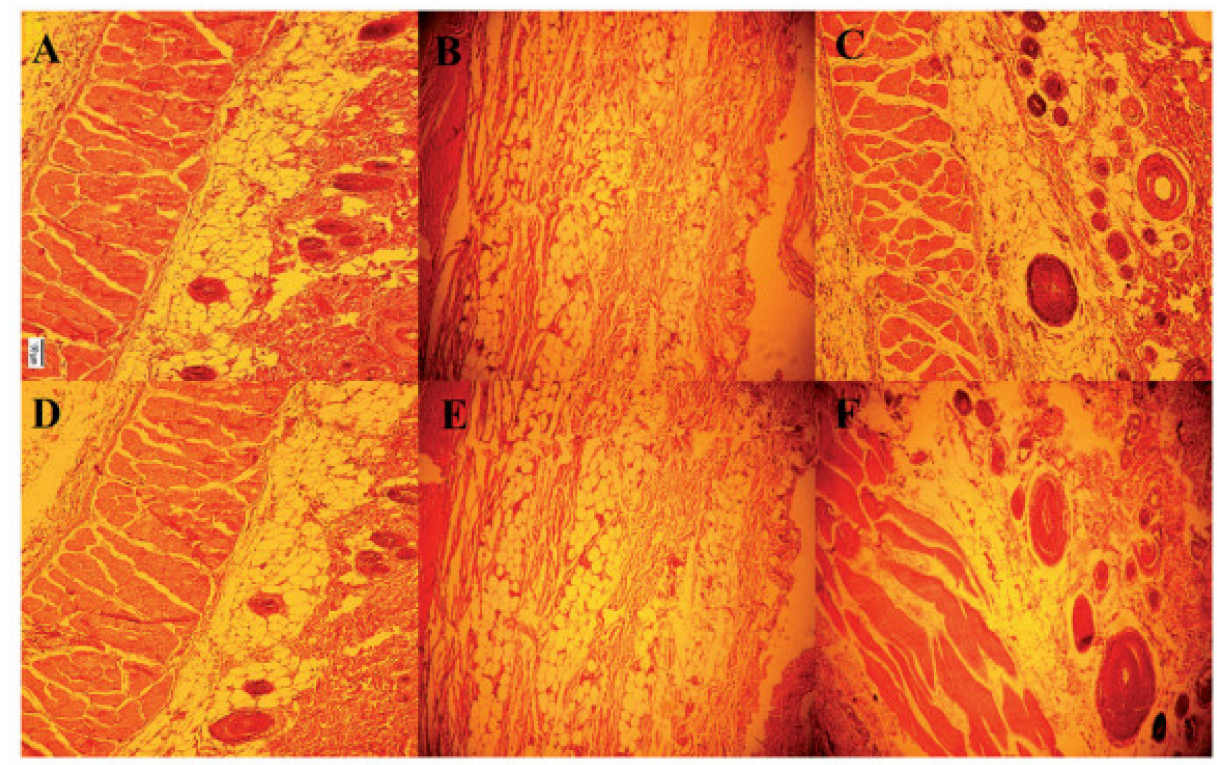

Figure 10. Histopathology images of the skin: (1) without a treatment after 7 days (A) and 21 days (D); (2) treated with caffeine hydrogel after 7 days (B) and 21 days (E); and (3) treated with caffeine-SLNhydrogel after 7 days (C) and 21 days (F). Reproduced with permission from [476] [ Copyright Clearance Center], [Drug Development and Industrial Pharmacy]; published by [Taylor \& Francis, 2015].

\subsubsection{Anti-hyper Pigmentation Activity}

Hydroquinone is a tyrosinase inhibitor that has strong depigmenting properties and is used to lighten areas of darkened skin, such as freckles, age spots, chloasma, and melisma [483]. It is banned from the use in cosmetic products in Europe and the UK because of the acute and chronic adverse effects associated with its use. Deoxyarbutin (4-[(tetrahydro-2H-pyran-2-yl)oxy]phenol) is a relatively new tyrosinase inhibitor, with stronger inhibitory potency than hydroquinone, but with decreased cytotoxicity. Tofani et al. developed deoxyarbutin-containing NLC for the treatment of hyperpigmentation and compared their skin penetration enhancement in dispersion and in hydroxypropyl methylcellulose gel to deoxyarbutin loaded nanoemulsion and the commercial cream emulsion [483]. The permeation of deoxyarbutin across the synthetic sebum membrane was the highest from the NLC incorporated into the gel. The permeation from the gel-NLC was comparable to the one from the nanoemulsion during the first two hours following the application, however later surpassed it. These kinetics was explained by the higher fluidity and elasticity of the nanoemulsion droplets on one hand, but the superior potential of NLC to release greater amounts of the drug over a prolonged period of time, on the other.

Additional recent advances in this field are summarized in Table 5. 
Table 5. Recent studies on nanoparticular cutaneous drug delivery systems in cosmetics and skincare.

\begin{tabular}{|c|c|c|c|}
\hline Type of Nanosystem & Drug/Active Material & Purpose & Reference \\
\hline SLN & Beeswax & $\begin{array}{c}\text { Formulation of beeswax loaded solid lipid } \\
\text { nanoparticles to improve damaged skin } \\
\text { barrier function }\end{array}$ & [484] \\
\hline SLN & Hydroquinone (banned in EU) & $\begin{array}{c}\text { Preparation of solid lipid nanoparticles } \\
\text { containing hydroquinone to treat } \\
\text { hyperpigmentation }\end{array}$ & [485] \\
\hline SLN & Curcumin & $\begin{array}{l}\text { Preparation of curcumin loaded solid lipid } \\
\text { nanoparticles-engrossed topical gel for the } \\
\text { treatment of pigmentation and irritant } \\
\text { contact dermatitis }\end{array}$ & [486] \\
\hline SLN & N-Acetyl-d-glucosamine & $\begin{array}{c}\text { Development of solid lipid nanoparticles } \\
\text { containing n-acetyl-d-glucosamine for } \\
\text { hyperpigmentation treatment }\end{array}$ & [487] \\
\hline NLC & Deoxyarbutin & $\begin{array}{c}\text { Development of deoxyarbutin loaded } \\
\text { nanostructured lipid carriers for } \\
\text { hyperpigmentation treatment }\end{array}$ & [483] \\
\hline NLC & MHY908 tyrosinase inhibitor & $\begin{array}{l}\text { Development of MHY908 loaded } \\
\text { nanostructured lipid carriers for } \\
\text { hyperpigmentation treatment }\end{array}$ & [488] \\
\hline NLC & N-Acetyl-glucosamine & $\begin{array}{l}\text { Development of n-acetyl-glucosamine } \\
\text { loaded nanostructured lipid carriers for } \\
\text { hyperpigmentation treatment }\end{array}$ & [489] \\
\hline NLC & Resveratrol & $\begin{array}{l}\text { Development of resveratrol loaded } \\
\text { nanostructured lipid carriers for } \\
\text { hyperpigmentation and } \\
\text { melanogenesis treatments }\end{array}$ & [490] \\
\hline SLN & Safranal & $\begin{array}{l}\text { Development of safranal loaded solid lipid } \\
\text { nanoparticles for sunscreen and moisturizing } \\
\text { potential for topical applications }\end{array}$ & [491] \\
\hline SLN & Aloe vera & $\begin{array}{c}\text { Formulation of photoprotective solid lipid } \\
\text { nanoparticles containing aloe vera as } \\
\text { sunscreen cream }\end{array}$ & [492] \\
\hline SLN & Green tea & $\begin{array}{l}\text { Preparation of solid lipid nanoparticles } \\
\text { containing green tea leaves (Camellia } \\
\text { sinensis L. Kuntze) extract as sunscreen }\end{array}$ & [493] \\
\hline SLN & Octyl methoxycinnamate & $\begin{array}{l}\text { Formulating octyl methoxycinnamate in } \\
\text { hybrid lipid-silica nanoparticles as UV skin } \\
\text { protection product }\end{array}$ & [494] \\
\hline NLC & Vegetable oils & $\begin{array}{l}\text { Preparation of nanostructured lipid carriers } \\
\text { containing various vegetable oils for UV } \\
\text { protection and antioxidant activity }\end{array}$ & [482] \\
\hline NLC & Naringenin & $\begin{array}{c}\text { Development of naringenin loaded } \\
\text { nanostructured lipid carriers as a } \\
\text { sunscreen product }\end{array}$ & [495] \\
\hline NLC & Acrocomia aculeata (arecaceae oil) & $\begin{array}{l}\text { Production of acrocomia aculeata (arecaceae } \\
\text { oil) loaded nanostructured lipid carriers for } \\
\text { photoprotective activity }\end{array}$ & [496] \\
\hline NLC & Amaranth and pumpkin seed oils & $\begin{array}{l}\text { Design of amaranth and pumpkin seed oils } \\
\text { loaded nanostructured lipid carriers as a new } \\
\text { cosmetic formulation with broad } \\
\text { photoprotective and antioxidative activities }\end{array}$ & [497] \\
\hline
\end{tabular}


Table 5. Cont.

\begin{tabular}{|c|c|c|c|}
\hline Type of Nanosystem & Drug/Active Material & Purpose & Reference \\
\hline NLC & $\begin{array}{c}\text { Carnauba wax, beeswax, and kenaf } \\
\text { seed oil }\end{array}$ & $\begin{array}{c}\text { Formulation of novel nanostructured lipid } \\
\text { carriers made from carnauba wax, beeswax, } \\
\text { and kenaf seed oil as a } \\
\text { photoprotective product }\end{array}$ & [498] \\
\hline NLC & Octyl methoxycinnamate & $\begin{array}{c}\text { Synthesis and characterization of octyl } \\
\text { p-methoxycinnamate loaded nanostructured } \\
\text { lipid carriers for enhanced sun protection } \\
\text { factor (SPF) for sunscreen }\end{array}$ & [499] \\
\hline NLC & $\begin{array}{l}\text { Protocatechuic acid and ethyl } \\
\text { protocatechuate }\end{array}$ & $\begin{array}{c}\text { Evaluation of lipid nanoparticles containing } \\
\text { protocatechuic acid and ethyl } \\
\text { protocatechuate as a new } \\
\text { photoprotection strategy }\end{array}$ & {$[500]$} \\
\hline SLN & Heptapeptide & $\begin{array}{c}\text { Development of heptapeptide loaded solid } \\
\text { lipid nanoparticles for cosmetic } \\
\text { anti-aging applications }\end{array}$ & [501] \\
\hline SLN & N-6-furfuryl adenine & $\begin{array}{l}\text { Development and evaluation of solid lipid } \\
\text { nanoparticles containing N-6-furfuryl } \\
\text { adenine for prevention of photoaging }\end{array}$ & [502] \\
\hline SLN & Proanthocyanidins & $\begin{array}{l}\text { Formulation of grape seed-derived } \\
\text { proanthocyanidins loaded solid lipid } \\
\text { nanoparticles to alleviate oxidative stress and } \\
\text { inflammation in airway epithelial cells }\end{array}$ & [503] \\
\hline SLN & Resveratrol & $\begin{array}{c}\text { Evolution of resveratrol loaded solid lipid } \\
\text { nanoparticles for anti-aging activities }\end{array}$ & [504] \\
\hline NLC & Coenzyme Q10 & $\begin{array}{l}\text { Development of coenzyme Q10 loaded } \\
\text { nanostructured lipid carriers as an inducer of } \\
\text { the skin fibroblast cell for anti-aging activity }\end{array}$ & [505] \\
\hline NLC & Folic acid & $\begin{array}{l}\text { Preparation of folic acid loaded lipid } \\
\text { nanocarriers with promoted skin anti-aging } \\
\text { and antioxidant efficacy }\end{array}$ & [506] \\
\hline NLC & Hesperidin & $\begin{array}{l}\text { Formulation of nanostructured lipid carrier } \\
\text { containing hesperidin from the orange } \\
\text { residue as anti-aging }\end{array}$ & [507] \\
\hline NLC & $\alpha$-Tocopherol & $\begin{array}{l}\text { Design of fatty acids based } \alpha \text {-tocopherol } \\
\text { loaded nanostructured lipid carrier gel for } \\
\text { moisturizing and anti-aging effects }\end{array}$ & [508] \\
\hline NLC & $\begin{array}{l}\text { Coenzyme Q10 and myrica } \\
\text { esculenta leaves extract }\end{array}$ & $\begin{array}{l}\text { Preparation of nanostructured lipid carriers } \\
\text { containing coenzyme Q10 and myrica } \\
\text { esculenta leaves extract for anti-aging activity }\end{array}$ & [509] \\
\hline NLC & Vitamin E & $\begin{array}{c}\text { Characterization and biocompatibility } \\
\text { evaluation of cutaneous formulations } \\
\text { containing vitamin E loaded nanostructured } \\
\text { lipid carriers for anti-aging activity }\end{array}$ & [467] \\
\hline SLN & Serine & $\begin{array}{l}\text { Preparation serine loaded solid lipid } \\
\text { nanoparticles and polysaccharide-rich extract } \\
\text { of root Phragmites communis incorporated } \\
\text { in hydrogel bases for a moisturizing effect }\end{array}$ & [510] \\
\hline SLN & Jojoba oil and grape seed oil & $\begin{array}{c}\text { Synthesis and characterization of } \\
\text { valacyclovir } \mathrm{HCl} \text { hybrid solid lipid } \\
\text { nanoparticles containing natural oils such as } \\
\text { jojoba oil and grape oil for antioxidant and } \\
\text { moisturizing activity }\end{array}$ & [511] \\
\hline
\end{tabular}


Table 5. Cont

\begin{tabular}{|c|c|c|c|}
\hline Type of Nanosystem & Drug/Active Material & Purpose & Reference \\
\hline NLC & Curcumin & $\begin{array}{l}\text { Development of nanostructured lipid carriers } \\
\text { based on monoacyl-phosphatidylcholine } \\
\text { containing curcumin for natural moisturizing }\end{array}$ & [512] \\
\hline NLC & Ellagic acid & $\begin{array}{c}\text { Formulation of ellagic acid loaded } \\
\text { nanostructured lipid carriers for topical } \\
\text { antioxidant activity }\end{array}$ & [513] \\
\hline Niosomes & Caffeine & $\begin{array}{l}\text { Preparation and evaluation of niosomes } \\
\text { containing caffeine as an anti-cellulite drug }\end{array}$ & [514] \\
\hline Liposomes & Azelaic acid & $\begin{array}{c}\text { Development of new effective azelaic acid } \\
\text { liposomal gel formulation of enhanced } \\
\text { pharmaceutical bioavailability for } \\
\text { anti-acne treatments }\end{array}$ & [515] \\
\hline Niosomes & Rosmarinic acid & $\begin{array}{l}\text { Development of a novel anti-acne niosomal } \\
\text { gel of rosmarinic acid }\end{array}$ & [516] \\
\hline Liposomes & Sodium copper chlorophyllin & $\begin{array}{l}\text { Preparation of liposomal sodium copper } \\
\text { chlorophyllin complex for anti-acne activities }\end{array}$ & [517] \\
\hline Liposomes & $\begin{array}{l}\text { Phenols recovered from olive mill } \\
\text { wastewater }\end{array}$ & $\begin{array}{l}\text { Formulation of liposomes containing phenols } \\
\text { recovered from olive mill wastewater as UV } \\
\text { booster in cosmetics }\end{array}$ & [518] \\
\hline Liposomes & Epigallocatechin-3-gallate & $\begin{array}{l}\text { Preparation of epigallocatechin-3-gallate } \\
\text { loaded liposomes against UV irradiation }\end{array}$ & [519] \\
\hline Liposomes & Isooctyl p-methoxycinnamate & $\begin{array}{l}\text { Encapsulation of isooctyl } \\
\text { p-methoxycinnamate with sodium } \\
\text { deoxycholate mediated liposomes } \\
\text { endocytosis for enhanced antioxidation and } \\
\text { photo protecting }\end{array}$ & [520] \\
\hline Liposomes & $\begin{array}{l}\text { methyl-2-acetylamino-3-(4- } \\
\text { hydroxyl-3,5- } \\
\text { dimethoxybenzoylthio) } \\
\text { propanoate }\end{array}$ & $\begin{array}{l}\text { Development of methyl-2-acetylamino-3-(4- } \\
\text { hydroxyl-3,5-dimethoxybenzoylthio) } \\
\text { propanoate loaded liposomes for } \\
\text { hyperpigmentation treatments }\end{array}$ & [352] \\
\hline Ethosomes & Epigallocatechin-3-gallate & $\begin{array}{l}\text { Formulation of nanoethosomal suspensions } \\
\text { of (-)-epigallocatechin gallate for enhancing } \\
\text { the effectiveness against UVB }\end{array}$ & [521] \\
\hline Niosomes & Octyl methoxycinnamate & $\begin{array}{l}\text { Formulations for photoprotective niosomes } \\
\text { containing octyl methoxycinnamate }\end{array}$ & [522] \\
\hline Ethosomes & Naringin & $\begin{array}{c}\text { Preparation of naringin loaded } \\
\text { nanoethosomal novel sunscreen creams }\end{array}$ & [523] \\
\hline Transfersomes & $\begin{array}{l}\text { Epigallocatechin-3-gallate and } \\
\text { hyaluronic acid }\end{array}$ & $\begin{array}{l}\text { Design of epigallocatechin-3-gallate and } \\
\text { hyaluronic acid loaded nanotransfersomes } \\
\text { for antioxidant and anti-aging effects in UV } \\
\text { radiation-induced skin damage }\end{array}$ & [524] \\
\hline Liposomes & Polygonum aviculare extract & $\begin{array}{c}\text { Preparation of cell-penetrating peptide } \\
\text { conjugated polygonum aviculare extract } \\
\text { loaded liposomes as a delivery system for } \\
\text { anti-aging activity }\end{array}$ & [525] \\
\hline Niosomes & Coenzyme Q10 & $\begin{array}{c}\text { Development of coenzyme Q10 loaded } \\
\text { niosomes for treatment of } \\
\text { photoinduced aging }\end{array}$ & [526] \\
\hline Niosomes & Gallic acid & $\begin{array}{l}\text { Formulation of gallic acid loaded in cationic } \\
\text { surfactant (cetrimonium bromide) niosomes } \\
\text { for anti-aging activity }\end{array}$ & [527] \\
\hline
\end{tabular}


Table 5. Cont

\begin{tabular}{|c|c|c|c|}
\hline Type of Nanosystem & Drug/Active Material & Purpose & Reference \\
\hline Ethosomes & Gamma oryzanol & $\begin{array}{c}\text { Formulation of ethosomes containing } \\
\text { gamma oryzanol for skin-aging protection } \\
\text { and wrinkle improvement }\end{array}$ & [528] \\
\hline Liposomes & Ascorbic acid derivative & $\begin{array}{l}\text { Development of ascorbic acid derivative } \\
\text { loaded liposomes for anti-aging activity }\end{array}$ & [529] \\
\hline Ethosomes and liposomes & Rosmarinic acid & $\begin{array}{c}\text { Formulation of rosmarinic acid loaded } \\
\text { ethosomes and liposomes as an } \\
\text { anti-aging product }\end{array}$ & [530] \\
\hline Liposomes & Vitamin D3 (banned in EU) & $\begin{array}{l}\text { Preparation of liposomes containing vitamin } \\
\text { D3 as an anti-aging agent for the skin }\end{array}$ & [531] \\
\hline Niosomes & Curcumin & $\begin{array}{c}\text { Formulation of niosomes containing } \\
\text { curcumin for anti-aging activity }\end{array}$ & [532] \\
\hline Niosomes & Volvariella volvacea extract & $\begin{array}{l}\text { Development of delivery enhancement of gel } \\
\text { containing niosomes containing volvariella } \\
\text { volvacea extract for anti-aging applications }\end{array}$ & [533] \\
\hline Transfersomes & Gotu kola leaves extract & $\begin{array}{c}\text { Formulation of transfersomes gel containing } \\
\text { gotu kola leaves extract for } \\
\text { anti-aging applications }\end{array}$ & [534] \\
\hline Liposomes & Argan oil and phospholipids & $\begin{array}{l}\text { Preparation of a mix of argan oil and } \\
\text { phospholipids for the development of an } \\
\text { effective liposomal system to improve skin } \\
\text { hydration and allantoin dermal delivery }\end{array}$ & [535] \\
\hline Transfersomes & Tocopherol & $\begin{array}{l}\text { Preparation of tocopherol loaded } \\
\text { transfersomes for skin regeneration }\end{array}$ & [536] \\
\hline Ethosomes & Rutin & $\begin{array}{l}\text { Formulation of rutin loaded ethosomes as an } \\
\text { antioxidant agent }\end{array}$ & [537] \\
\hline Transfersomes & Photocomplexes from grape seeds & $\begin{array}{l}\text { Development of transfersomes containing } \\
\text { photocomplexes extracted from grape seeds } \\
\text { for the treatment of skin damages }\end{array}$ & [538] \\
\hline Nanoemulsion & $\begin{array}{l}\text { Centella asiatica L. and zingiber } \\
\text { officinale }\end{array}$ & $\begin{array}{l}\text { Design of nanoemulsion containing centella } \\
\text { asiatica L. and zingiber officinale } \\
\text { combination to promote collagen synthesis } \\
\text { and decrease the diameter of adipocyte cells } \\
\text { for anti-cellulite treatment }\end{array}$ & [539] \\
\hline Nanoemulsion & Caffeine & $\begin{array}{l}\text { Development of nanoemulsion containing } \\
\text { caffeine for cellulite treatment }\end{array}$ & [540] \\
\hline Nanoemulsion & Origanum vulgare L. essential oil & $\begin{array}{c}\text { Formulation of origanum vulgare L. essential } \\
\text { oil loaded nanoemulsion as a potential } \\
\text { anti-acne drug }\end{array}$ & [541] \\
\hline Nanoemulsion & Polyphenol-rich ethyl acetate & $\begin{array}{l}\text { Development of photoprotection by Punica } \\
\text { granatum seed oil nanoemulsion entrapping } \\
\text { polyphenol-rich ethyl acetate fraction } \\
\text { against UVB }\end{array}$ & [542] \\
\hline Nanoemulsion & Chitosan & $\begin{array}{l}\text { Preparation of a photoprotective and } \\
\text { antioxidant nanoemulsion containing } \\
\text { chitosan as an agent for improving } \\
\text { skin retention }\end{array}$ & [543] \\
\hline Nanoemulsion & Sunflower oil & $\begin{array}{l}\text { Preparation and evaluation of sunflower oil } \\
\text { nanoemulsion as a sunscreen product }\end{array}$ & [544] \\
\hline
\end{tabular}


Table 5. Cont.

\begin{tabular}{|c|c|c|c|}
\hline Type of Nanosystem & Drug/Active Material & Purpose & Reference \\
\hline Nanoemulsion & $\begin{array}{l}\text { Soybean oil, avobenzone, and octyl } \\
\text { methoxycinnamate }\end{array}$ & $\begin{array}{l}\text { Preparation and evaluation of sunscreen } \\
\text { nanoemulsions containing soybean oil, } \\
\text { avobenzone, and octyl methoxycinnamate, } \\
\text { with synergistic efficacy on SPF }\end{array}$ & [545] \\
\hline Nanoemulsion & Rambutan fruit peel extracts & $\begin{array}{l}\text { Formulation of gel nanoemulsion of } \\
\text { rambutan for sunscreen protecting and } \\
\text { antioxidant activity }\end{array}$ & [546] \\
\hline Nanoemulsion & Vitamin $\mathrm{E}$ and genistein & $\begin{array}{l}\text { Development of vitamin E-enriched } \\
\text { nanoemulsion containing genistein for } \\
\text { chemoprevention against UVB }\end{array}$ & [547] \\
\hline Nanoemulsion & Quercetin tetraethyl ether & $\begin{array}{c}\text { Preparation and characterization of a } \\
\text { quercetin tetraethyl ether loaded } \\
\text { nanoemulsion as photoprotective product }\end{array}$ & [548] \\
\hline Microemulsion & Resveratrol & $\begin{array}{l}\text { Microemulsion containing polyoxyethylene } \\
\text { sorbitan trioleate and resveratrol for skin } \\
\text { protection against UV }\end{array}$ & [301] \\
\hline Microemulsion & Quercetin & $\begin{array}{l}\text { Formulation of quercetin loaded } \\
\text { microemulsion for topical } \\
\text { sunscreen application }\end{array}$ & [549] \\
\hline Microemulsion & Octyl p-methoxycinnamate & $\begin{array}{l}\text { Preparation of octyl p-methoxycinnamate } \\
\text { loaded microemulsion based on ocimum } \\
\text { basilicum essential oil for potential cosmetic } \\
\text { applications such as sunscreen }\end{array}$ & [550] \\
\hline Nanoemulsion & Kojic monooleate & $\begin{array}{c}\text { Development of kojic monooleate loaded } \\
\text { nanoemulsion for } \\
\text { hyperpigmentation treatments }\end{array}$ & {$[551]$} \\
\hline Nanoemulsion & Azelaic acid with hyaluronic acid & $\begin{array}{l}\text { Development of azelaic acid with hyaluronic } \\
\text { acid loaded nanoemulsion for } \\
\text { hyperpigmentation treatments }\end{array}$ & [552] \\
\hline Nanoemulsion & Vitamin C & $\begin{array}{l}\text { Development of vitamin C loaded } \\
\text { nanoemulsion for } \\
\text { hyperpigmentation treatments }\end{array}$ & [553] \\
\hline Nanoemulsion & Adlay bran oil & $\begin{array}{c}\text { Development of adlay bran oil loaded } \\
\text { nanoemulsion for } \\
\text { hyperpigmentation treatments }\end{array}$ & {$[554]$} \\
\hline Microemulsion & Kojic acid and arbutin & $\begin{array}{c}\text { Development of kojic acid and arbutin } \\
\text { loaded microemulsion for } \\
\text { hyperpigmentation treatments }\end{array}$ & [555] \\
\hline Microemulsion & $\begin{array}{l}\text { Cistanche tubulosa phenylethanoid } \\
\text { glycosides }\end{array}$ & $\begin{array}{c}\text { Preparation and evaluation of microemulsion } \\
\text { containing cistanche tubulosa } \\
\text { phenylethanoid glycosides for skin } \\
\text { lightning activity }\end{array}$ & [556] \\
\hline Microemulsion & Dibenzoylmethane & $\begin{array}{l}\text { Development of microemulsion containing } \\
\text { dibenzoylmethane for treatment of UV } \\
\text { induced photoaging }\end{array}$ & [557] \\
\hline Microemulsion & Melaleuca cajuputi essential oil & $\begin{array}{l}\text { Formulation of microemulsion containing } \\
\text { extract from melaleuca cajuputi essential oil } \\
\text { using nonionic surfactant for } \\
\text { sunscreen activity }\end{array}$ & [558] \\
\hline Microemulsion & $\begin{array}{l}\text { Mangosteen pericarp (Garcinia } \\
\text { mangostana Linn.) }\end{array}$ & $\begin{array}{l}\text { Development of microemulsion gel } \\
\text { containing n-hexane fraction of mangosteen } \\
\text { pericarp as a sunscreen product }\end{array}$ & [559] \\
\hline
\end{tabular}


Table 5. Cont

\begin{tabular}{|c|c|c|c|}
\hline Type of Nanosystem & Drug/Active Material & Purpose & Reference \\
\hline Nanoemulsion & Grapeseed oil & $\begin{array}{l}\text { Evaluation of the effect of antioxidant of } \\
\text { grapeseed oil loaded nanoemulsion for skin } \\
\text { anti-aging purposes }\end{array}$ & [560] \\
\hline Nanoemulsion & Coenzyme Q10 & $\begin{array}{c}\text { Design of coenzyme Q10 loaded } \\
\text { nanoemulsion with improved skin } \\
\text { permeability and anti-wrinkle efficiency }\end{array}$ & [466] \\
\hline Nanoemulsion & $\begin{array}{l}\text { Copper peptide and virgin coconut } \\
\text { oil }\end{array}$ & $\begin{array}{c}\text { Formulation of nanoemulsion based virgin } \\
\text { coconut oil containing copper peptide for } \\
\text { anti-aging activity }\end{array}$ & [561] \\
\hline Microemulsion & Camellia assamica seed oil & $\begin{array}{c}\text { Development of camellia assamica seed oil } \\
\text { loaded microemulsion for antioxidant and } \\
\text { moisturizing activities }\end{array}$ & [562] \\
\hline Microemulsion & Binahong leaf extract & $\begin{array}{c}\text { Formulation of binahong (anredera cordifolia } \\
\text { steenis) leaf extract loaded microemulsion } \\
\text { as anti-aging }\end{array}$ & [563] \\
\hline Nanoemulsion & $\begin{array}{l}\text { Opuntia ficus-indica (L.) mill } \\
\text { extract }\end{array}$ & $\begin{array}{l}\text { Production of cosmetic nanoemulsions } \\
\text { containing opuntia ficus-indica L. mill } \\
\text { extracts for moisturizing activity }\end{array}$ & [458] \\
\hline Nanoemulsion & Agave sisalana & $\begin{array}{l}\text { Preparation of agave sisalana as a new } \\
\text { cosmetic raw material loaded nanoemulsion } \\
\text { to improve skin moisturizing }\end{array}$ & [564] \\
\hline Nanoemulsion & Exotic vegetable oils & $\begin{array}{c}\text { Development of exotic vegetable oils loaded } \\
\text { O/W nanoemulsions for } \\
\text { moisturizing applications }\end{array}$ & [565] \\
\hline Nanoemulsion & Sweet fennel essential oil & $\begin{array}{l}\text { Formulation of } \mathrm{O} / \mathrm{W} \text { nanoemulsion } \\
\text { containing sweet fennel essential oil for } \\
\text { antioxidant applications }\end{array}$ & [566] \\
\hline Nanoemulsion & Achyrocline satureioides extract & $\begin{array}{l}\text { Development of nanoemulsion containing } \\
\text { achyrocline satureioides extract for treatment } \\
\text { against UV-induced skin damage }\end{array}$ & [567] \\
\hline Nanoemulsion & Tea tree oil & $\begin{array}{c}\text { Formulation of tea tree oil loaded } \\
\text { nanoemulsion for antimicrobial applications }\end{array}$ & [568] \\
\hline Nanocapsules & Rose-hip oil & $\begin{array}{l}\text { Formulation of nanocapsules based on } \\
\text { eudrgait RS100 containing rose-hip oil for } \\
\text { skin regeneration }\end{array}$ & [569] \\
\hline Nanocapsules & Benzophenone-3 & $\begin{array}{c}\text { Development of a new sunscreen } \\
\text { formulation based on benzophenone-3 } \\
\text { loaded poly( } \varepsilon \text {-caprolactone) nanocapsules }\end{array}$ & [570] \\
\hline Nanospheres & 5-Hydroxymethylfurfural & $\begin{array}{c}\text { Formulation of mesosilica-supported } \\
\text { 5-hydroxymethylfurfural nanospheres to } \\
\text { protect against UV-induced aging of human } \\
\text { dermal fibroblasts }\end{array}$ & [571] \\
\hline Nanocapsules & $\begin{array}{l}\text { Dead sea water and retinyl } \\
\text { palmitate }\end{array}$ & $\begin{array}{l}\text { Formulation of dead sea water and retinyl } \\
\text { palmitate loaded poly(3-hydroxybutyrateco- } \\
\text { 3-hydroxyvalerate) micro/nanocapsules for } \\
\text { the treatment of psoriasis, aging, or } \\
\text { UV damage }\end{array}$ & [572] \\
\hline Microcapsules & Grape seed oil & $\begin{array}{c}\text { Formulation of ethylcellulose microcapsules } \\
\text { containing grape seed oil for skin } \\
\text { moisturizing activity }\end{array}$ & [534] \\
\hline
\end{tabular}


Table 5. Cont.

\begin{tabular}{|c|c|c|c|}
\hline Type of Nanosystem & Drug/Active Material & Purpose & Reference \\
\hline Microspheres & olive leaf extract & $\begin{array}{c}\text { Preparation of olive leaf extract loaded } \\
\text { chitosan microspheres for } \\
\text { moisturizing activity }\end{array}$ & [573] \\
\hline Microspheres & Glutathione & $\begin{array}{l}\text { Development of glutathione loaded alginate } \\
\text { microspheres for topical anti-aging activity }\end{array}$ & [574] \\
\hline Microspheres & Lignin & $\begin{array}{l}\text { Fabrication of light-colored lignin } \\
\text { microspheres for developing } \\
\text { natural sunscreens }\end{array}$ & [575] \\
\hline Microspheres & 4-Methylbenzylidene camphor 1 & $\begin{array}{l}\text { Formulation of 4-methylbenzylidene } \\
\text { camphor loaded microspheres based on } \\
\text { hydrophilic (chitosan and gelatine) and } \\
\text { hydrophobic (polymethylmetacrylate) } \\
\text { polymers for sunscreen activity }\end{array}$ & [576] \\
\hline Microcapsules & Octyl methoxycinnamate & $\begin{array}{l}\text { Preparation and characterization of } \\
\text { microcapsules based on gelatin and sodium } \\
\text { polyphosphate encapsulating octyl } \\
\text { methoxycinnamate for } \\
\text { sunscreen applications }\end{array}$ & [577] \\
\hline Nanospheres & Lignin and benzophenone & $\begin{array}{l}\text { Formulation of lignin nanospheres with } \\
\text { broad-spectrum UV adsorption and excellent } \\
\text { antioxidant properties containing } \\
\text { benzophenone for sunscreen activity }\end{array}$ & [578] \\
\hline Nanospheres & Vitamin C & $\begin{array}{l}\text { Preparation of nanospheres based on ethyl } \\
\text { cellulose encapsulating vitamin } C \text { for } \\
\text { hyperpigmentation treatments }\end{array}$ & [160] \\
\hline
\end{tabular}

\section{Conclusions}

It is evident from this immense number of recent works that nanomaterials play the most significant role in the contemporary dermal delivery research. Nanocarriers can effectively protect active materials from degradation on the skin surface, increase their concentration in the upper skin layers and enable graduate release, thus creating a prolonged local concentration gradient in the skin. It is important to remember though, that the permeation enhancement effect of nanomaterials rarely stems from the ability of the whole particle to penetrate deeper than the epidermis (with the exceptions of soft vesicles, deformable particles, and nanodroplets), but mostly from the capacity to create favorable conditions for the permeation of the active compound itself. In transdermal delivery, nanocarriers were shown to maintain the therapeutic concentrations of drug in plasma for prolonged periods of time, as well as to increase the overall drug amount that reaches the bloodstream over time. This effect can be explained by: (1) the sustained release of the drug from the skin by creating a concentrated drug depot within the skin, (2) the avoidance of the first-pass effect that takes place in oral administration of many drugs. Main challenges in the development of cutaneous nanometric delivery systems include: (1) incorporation and the effective cutaneous release of active compounds with a wide spectrum of physicochemical properties, (2) ensuring low skin irritability of nanocarriers and permeation enhancers, (3) precise delivery to various skin strata and across the skin depending on the final target, (4) overcoming toxicity concerns regarding nanomaterials in topical medical formulations and cosmetics.

Author Contributions: A.Z. conceived the idea, reviewed the literature, wrote the manuscript; E.T. revised the content, wrote the manuscript; K.M. conceived the idea, reviewed the literature, wrote the manuscript. All authors have read and agreed to the published version of the manuscript. 
Funding: The research was supported by Israel Science Foundation grant number 1840/20, United States-Israel Binational Science Foundation grant number 2019237 and Israel Cancer Research Fund grant number 20-204-RCDA.

Institutional Review Board Statement: Not applicable.

Informed Consent Statement: Not applicable.

Data Availability Statement: No data was generated.

Conflicts of Interest: The authors declare no conflict of interest.

\section{References}

1. Scheuplein, R.J. Analysis of Permeability Data for the Case of Parallel Diffusion Pathways. Biophys. J. 1966, 6, 1-17. [CrossRef]

2. Bouwstra, J.A.; Honeywell-Nguyen, P.L.; Gooris, G.S.; Ponec, M. Structure of the skin barrier and its modulation by vesicu-lar formulations. Prog. Lipid Res. 2003, 42, 1-36. [CrossRef]

3. Godin, B.; Touitou, E. Transdermal skin delivery: Predictions for humans from in vivo, ex vivo and animal models. Adv. Drug Deliv. Rev. 2007, 59, 1152-1161. [CrossRef] [PubMed]

4. Shumilov, M.; Bercovich, R.; Duchi, S.; Ainbinder, D.; Touitou, E. Ibuprofen transdermal ethosomal gel: Characterization and efficiency in animal models. J. Biomed. Nanotechnol. 2010, 6, 569-576. [CrossRef] [PubMed]

5. Barry, B.W. Novel mechanisms and devices to enable successful transdermal drug delivery. Eur. J. Pharm. Sci. 2001, 14, 101-114. [CrossRef]

6. Jepps, O.G.; Dancik, Y.; Anissimov, Y.G.; Roberts, M.S. Modeling the human skin barrier-Towards a better understanding of dermal absorption. Adv. Drug Deliv. Rev. 2013, 65, 152-168. [CrossRef]

7. Van Smeden, J.; Janssens, M.; Gooris, G.; Bouwstra, J. The important role of stratum corneum lipids for the cutaneous barrier function. Biochim. Biophys. Acta (BBA) Mol. Cell Biol. Lipids 2014, 1841, 295-313. [CrossRef]

8. Touitou, E.; Godin, B. Ethosomes for skin delivery. J. Drug Deliv. Sci. Technol. 2007, 17, 303-308. [CrossRef]

9. Hwa, C.; Bauer, E.A.; Cohen, D.E. Skin biology. Dermatol. Ther. 2011, 24, 464-470. [CrossRef]

10. Alexander, A.; Dwivedi, S.; Ajazuddin; Giri, T.G.; Saraf, S.; Saraf, S.; Tripathi, D.K. Approaches for breaking the barriers of drug permeation through transdermal drug delivery. J. Control. Release 2012, 164, 26-40. [CrossRef]

11. Frasch, H.F.; Barbero, A.M. Application of numerical methods for diffusion-based modeling of skin permeation. Adv. Drug Deliv. Rev. 2013, 65, 208-220. [CrossRef]

12. Notman, R.; Anwar, J. Breaching the skin barrier-Insights from molecular simulation of model membranes. Adv. Drug Deliv. Rev. 2013, 65, 237-250. [CrossRef] [PubMed]

13. Scheuplein, R.J.; Blank, I.H. Permeability of the skin. Physiol. Rev. 1971, 51, 702-747. [CrossRef]

14. Walters, K.A.; Brain, K.R. Dermatological Formulation and Transdermal Systems. Pharm. Dissolution Test. 2002, 119, 315-395. [CrossRef]

15. Illel, B.; Schaefer, H.; Wepierre, J.; Doucet, O. Follicles Play an Important Role in Percutaneous Absorption. J. Pharm. Sci. 1991, 80, 424-427. [CrossRef]

16. Fang, C.-L.; Aljuffali, I.A.; Li, Y.-C.; Fang, J.-Y. Delivery and targeting of nanoparticles into hair follicles. Ther. Deliv. 2014, 5, 991-1006. [CrossRef]

17. Prost-Squarcioni, C. Histology of skin and hair follicle. Med. Sci. 2006, 22, 131-137.

18. Sala, M.; Diab, R.; Elaissari, A.; Fessi, H. Lipid nanocarriers as skin drug delivery systems: Properties, mechanisms of skin interactions and medical applications. Int. J. Pharm. 2018, 535, 1-17. [CrossRef]

19. Baron, J.M.; Merk, H.F. Drug metabolism in the skin. Curr. Opin. Allergy Clin. Immunol. 2001, 1, 287-291. [CrossRef] [PubMed]

20. Pyo, S.M.; Maibach, H.I. Skin Metabolism: Relevance of Skin Enzymes for Rational Drug Design. Ski. Pharmacol. Physiol. 2019, 32, 283-294. [CrossRef] [PubMed]

21. Schneider, M.; Stracke, F.; Hansen, S.; Schaefer, U.F. Nanoparticles and their interactions with the dermal barrier. Derm. Endocrinol. 2009, 1, 197-206. [CrossRef] [PubMed]

22. Cevc, G.; Gebauer, D. Hydration-Driven Transport of Deformable Lipid Vesicles through Fine Pores and the Skin Barrier. Biophys. J. 2003, 84, 1010-1024. [CrossRef]

23. Müller, R.H.; Radtke, M.; Wissing, S.A. Solid lipid nanoparticles (SLN) and nanostructured lipid carriers (NLC) in cosmetic and dermatological preparations. Advanced Drug Delivery Reviews 2002, 54 (Suppl 1), S131-S155. [CrossRef]

24. Zhang, J.; Purdon, C.H.; Smith, E.W. Solid Lipid Nanoparticles for Topical Drug Delivery. Am. J. Drug Deliv. 2006, 4, 215-220. [CrossRef]

25. Mehnert, W.; Mäder, K. Solid lipid nanoparticles: Production, characterization and applications. Adv. Drug Deliv. Rev. 2001, 47, 165-196. [CrossRef]

26. Godin, B.; Touitou, E. Ethosomes: New prospects in transdermal delivery. Crit. Rev. Ther. Drug Carr. Syst. 2003, $20,63-102$. [CrossRef]

27. Benson, H.A. Transfersomes for transdermal drug delivery. Expert Opin. Drug Deliv. 2006, 3, 727-737. [CrossRef] 
28. Schreier, H.; Bouwstra, J. Liposomes and niosomes as topical drug carriers: Dermal and transdermal drug delivery. J. Control. Release 1994, 30, 1-15. [CrossRef]

29. Danielsson, I.; Lindman, B. The definition of microemulsion. Colloids Surf. 1981, 3, 391-392. [CrossRef]

30. Nastiti, C.M.R.R.; Ponto, T.; Abd, E.; Grice, J.E.; Benson, H.A.E.; Roberts, M.S. Topical Nano and Microemulsions for Skin Delivery. Pharmaceutics 2017, 9, 37. [CrossRef]

31. Yang, H.; Leffler, C.T. Hybrid Dendrimer Hydrogel/Poly(Lactic-Co-Glycolic Acid) Nanoparticle Platform: An Advanced Vehicle for Topical Delivery of Antiglaucoma Drugs and a Likely Solution to Improving Compliance and Adherence in Glaucoma Management. J. Ocul. Pharmacol. Ther. 2013, 29, 166-172. [CrossRef] [PubMed]

32. Verreck, G.; Chun, I.; Rosenblatt, J.; Peeters, J.; Van Dijck, A.; Mensch, J.; Noppe, M.; Brewster, M.E. Incorporation of drugs in an amorphous state into electrospun nanofibers composed of a water-insoluble, nonbiodegradable polymer. J. Control. Release 2003, 92, 349-360. [CrossRef]

33. Kim, S.; Shi, Y.; Kim, J.Y.; Park, K.; Cheng, J.-X. Overcoming the barriers in micellar drug delivery: Loading efficiency, in vivostability, and micelle-cell interaction. Expert Opin. Drug Deliv. 2009, 7, 49-62. [CrossRef] [PubMed]

34. Guimarães, K.L.; Ré, M.I. Lipid Nanoparticles as Carriers for Cosmetic Ingredients: The First (SLN) and the Second Generation (NLC). In Nanocosmetics and Nanomedicines: New Approaches for Skin Care; Beck, R.G., Pohlmann, S.A., Eds.; Springer: Berlin/Heidelberg, Germany, 2011; pp. 101-122.

35. Kovacevic, A.; Savic, S.; Vuleta, G.; Müller, R.H.; Keck, C.M. Polyhydroxy surfactants for the formulation of lipid nanopar-ticles (SLN and NLC): Effects on size, physical stability and particle matrix structure. Int. J. Pharm. 2011, 406, 163-172. [CrossRef] [PubMed]

36. Pardeike, J.; Hommoss, A.; Müller, R.H. Lipid nanoparticles (SLN, NLC) in cosmetic and pharmaceutical dermal products. Int. J. Pharm. 2009, 366, 170-184. [CrossRef] [PubMed]

37. Battaglia, L.; Gallarate, M. Lipid nanoparticles: State of the art, new preparation methods and challenges in drug delivery. Expert Opin. Drug Deliv. 2012, 9, 497-508. [CrossRef]

38. Müller, R.H.; Shegokar, R.; Keck, C.M. 20 years of lipid nanoparticles (SLN \& NLC): Present state of development \& indus-trial applications. Curr. Drug Discov. Technol. 2011, 8, 207-227.

39. Del Pozo-Rodríguez, A.; Delgado, D.; Gascón, A.R.; Solinís, M. Ángeles Lipid Nanoparticles as Drug/Gene Delivery Systems to the Retina. J. Ocul. Pharmacol. Ther. 2013, 29, 173-188. [CrossRef] [PubMed]

40. Gratieri, T.; Krawczyk-Santos, A.P.; da Rocha, P.B.R.; Cunha; Filho, M.; Gelfuso, G.M.; Marreto, R.N.; Taveira, S.F. SLN- and NLC-Encapsulating Antifungal Agents: Skin Drug Delivery and their Unexplored Potential for Treating Onychomycosis. Curr. Pharm. Des. 2017, 23, 6684-6695. [CrossRef]

41. Naseri, N.; Valizadeh, H.; Zakeri-Milani, P. Solid Lipid Nanoparticles and Nanostructured Lipid Carriers: Structure, Preparation and Application. Adv. Pharm. Bull. 2015, 5, 305-313. [CrossRef]

42. Zhai, Y.; Zhai, G. Advances in lipid-based colloid systems as drug carrier for topic delivery. J. Control. Release 2014, 193, 90-99. [CrossRef]

43. Silva, A.C.; Amaral, M.H.; Lobo, J.M.S.; Lopes, C.M. Lipid nanoparticles for the delivery of biopharmaceuticals. Curr. Pharm. Biotechnol. 2015, 16, 291-302. [CrossRef] [PubMed]

44. Fang, C.-L.; Al-Suwayeh, S.A.; Fang, J.-Y. Nanostructured Lipid Carriers (NLCs) for Drug Delivery and Targeting. Recent Pat. Nanotechnol. 2013, 7, 41-55. [CrossRef] [PubMed]

45. Gordillo-Galeano, A.; Mora-Huertas, C.E. Solid lipid nanoparticles and nanostructured lipid carriers: A review emphasiz-ing on particle structure and drug release. Eur. J. Pharm. Biopharm. 2018, 133, 285-308. [CrossRef] [PubMed]

46. Ganesan, P.; Narayanasamy, D. Lipid nanoparticles: Different preparation techniques, characterization, hurdles, and strate-gies for the production of solid lipid nanoparticles and nanostructured lipid carriers for oral drug delivery. Sustain. Chem. Pharm. 2017, 6, 37-56. [CrossRef]

47. Wissing, S.A.; Kayser, O.; Müller, R.H. Solid lipid nanoparticles for parenteral drug delivery. Adv. Drug Deliv. Rev. 2004, 56, 1257-1272. [CrossRef] [PubMed]

48. Silva, A.C.; González-Mira, E.; García, M.L.; Egea, M.A.; Fonseca, J.; Silva, R.; Santos, D.; Souto, E.B.; Ferreira, D. Preparation, characterization and biocompatibility studies on risperidone-loaded solid lipid nanoparticles (SLN): High pressure ho-mogenization versus ultrasound. Colloids Surf. B Biointerfaces 2011, 86, 158-165. [CrossRef] [PubMed]

49. Heurtault, B.; Saulnier, P.; Pech, B.; Proust, J.-E.; Benoit, J.-P. A Novel Phase Inversion-Based Process for the Preparation of Lipid Nanocarriers. Pharm. Res. 2002, 19, 875-880. [CrossRef]

50. Schubert, M.A.; Müller-Goymann, C.C. Solvent injection as a new approach for manufacturing lipid nanoparticles-Evalua-tion of the method and process parameters. Eur. J. Pharm. Biopharm. 2003, 55, 125-131. [CrossRef]

51. Quintanar-Guerrero, D.; Tamayo-Esquivel, D.; Ganem-Quintanar, A.; Allémann, E.; Doelker, E. Adaptation and optimiza-tion of the emulsification-diffusion technique to prepare lipidic nanospheres. Eur. J. Pharm. Biopharm. 2005, 26, $211-218$.

52. Muchow, M.; Maincent, P.; Müller, R.H. Lipid Nanoparticles with a Solid Matrix (SLN, NLC, LDC) for Oral Drug Delivery. Drug Dev. Ind. Pharm. 2008, 34, 1394-1405. [CrossRef]

53. Desai, P.; Patlolla, R.R.; Singh, M. Interaction of nanoparticles and cell-penetrating peptides with skin for transdermal drug delivery. Mol. Membr. Biol. 2010, 27, 247-259. [CrossRef] [PubMed] 
54. Jensen, L.B.; Petersson, K.; Nielsen, H.M. In vitro penetration properties of solid lipid nanoparticles in intact and barri-er-impaired skin. Eur. J. Pharm. Biopharm. 2011, 79, 68-75. [CrossRef]

55. Butani, D.; Yewale, C.; Misra, A. Topical Amphotericin B solid lipid nanoparticles: Design and development. Colloids Surf. B Biointerfaces 2016, 139, 17-24. [CrossRef] [PubMed]

56. El-Housiny, S.; Shams Eldeen, M.A.; El-Attar, Y.A.; Salem, H.A.; Attia, D.; Bendas, E.R.; El-Nabarawi, M.A. Flucona-zole-loaded solid lipid nanoparticles topical gel for treatment of pityriasis versicolor: Formulation and clinical study. Drug Deliv. 2018, 25, 78-90. [CrossRef]

57. Carbone, C.; do Céu Teixeira, M.; do Céu Sousa, M.; Martins-Gomes, C.; Silva, A.M.; Souto, E.M.B.; Musumeci, T. Clotrimazole-Loaded Mediterranean Essential Oils NLC: A Synergic Treatment of Candida Skin Infections. Pharmaceutics 2019, 11, 231. [CrossRef] [PubMed]

58. Pivetta, T.P.; Simões, S.; Araújo, M.M.; Carvalho, T.; Arruda, C.; Marcato, P.D. Development of nanoparticles from natural lipids for topical delivery of thymol: Investigation of its anti-inflammatory properties. Colloids Surf. B Biointerfaces 2018, 164, 281-290. [CrossRef]

59. Gad, H.A.; El-Rahman, F.A.A.; Hamdy, G.M. Chamomile oil loaded solid lipid nanoparticles: A naturally formulated remedy to enhance the wound healing. J. Drug Deliv. Sci. Technol. 2019, 50, 329-338. [CrossRef]

60. Shrotriya, S.N.; Ranpise, N.S.; Vidhate, B.V. Skin targeting of resveratrol utilizing solid lipid nanoparticle-engrossed gel for chemically induced irritant contact dermatitis. Drug Deliv. Transl. Res. 2016, 7, 37-52. [CrossRef] [PubMed]

61. Okonogi, S.; Riangjanapatee, P. Physicochemical characterization of lycopene-loaded nanostructured lipid carrier formula-tions for topical administration. Int. J. Pharm. 2015, 478, 726-735. [CrossRef]

62. Kelidari, H.R.; Saeedi, M.; Akbari, J.; Morteza-Semnani, K.; Gill, P.; Valizadeh, H.; Nokhodchi, A. Formulation optimization and in vitro skin penetration of spironolactone loaded solid lipid nanoparticles. Colloids Surf. B Biointerfaces 2015, 128, 473-479. [CrossRef] [PubMed]

63. Ghate, V.M.; Lewis, S.A.; Prabhu, P.; Dubey, A.; Patel, N. Nanostructured lipid carriers for the topical delivery of tretinoin. Eur. J. Pharm. Biopharm. 2016, 108, 253-261. [CrossRef]

64. Malik, D.S.; Kaur, G. Exploring therapeutic potential of azelaic acid loaded NLCs for the treatment of acne vulgaris. J. Drug Deliv. Sci. Technol. 2020, 55, 101418. [CrossRef]

65. Lin, W.J.; Duh, Y.S. Nanostructured lipid carriers for transdermal delivery of acid labile lansoprazole. Eur. J. Pharm. Biopharm. 2016, 108, 297-303. [CrossRef] [PubMed]

66. Alam, S.; Aslam, M.; Khan, A.; Imam, S.S.; Aqil, M.; Sultana, Y.; Ali, A.; Aqil, M. Nanostructured lipid carriers of pioglitazone for transdermal application: From experimental design to bioactivity detail. Drug Deliv. 2014, 23, 601-609. [CrossRef]

67. Huber, L.A.; Pereira, T.A.; Ramos, D.N.; Rezende, L.C.D.; Emery, F.S.; Sobral, L.M.; Leopoldino, A.M.; Lopez, R.F. Topical Skin Cancer Therapy Using Doxorubicin-Loaded Cationic Lipid Nanoparticles and Iontophoresis. J. Biomed. Nanotechnol. 2015, 11, 1975-1988. [CrossRef] [PubMed]

68. Geetha, T.; Kapila, M.; Prakash, O.; Deol, P.K.; Kakkar, V.; Kaur, I.P. Sesamol-loaded solid lipid nanoparticles for treatment of skin cancer. J. Drug Target. 2014, 23, 159-169. [CrossRef]

69. Basha, M.; Abd El-Alim, S.H.; Kassem, A.A.; El Awdan, S.; Awad, G. Benzocaine loaded solid lipid nanoparticles: Formula-tion design, in vitro and in vivo evaluation of local anesthetic effect. Curr. Drug Deliv. 2015, 12, 680-692. [CrossRef]

70. Gainza, G.; Chu, W.S.; Guy, R.H.; Pedraz, J.L.; Hernandez, R.M.; Delgado-Charro, B.; Igartua, M. Development and in vitro evaluation of lipid nanoparticle-based dressings for topical treatment of chronic wounds. Int. J. Pharm. 2015, 490, 404-411. [CrossRef]

71. Harde, H.; Agrawal, A.K.; Katariya, M.; Kale, D.; Jain, S. Development of a topical adapalene-solid lipid nanoparticle load-ed gel with enhanced efficacy and improved skin tolerability. RSC Adv. 2015, 5, 43917-43929. [CrossRef]

72. Fumakia, M.; Ho, E.A. Nanoparticles Encapsulated with LL37 and Serpin A1 Promotes Wound Healing and Synergistically Enhances Antibacterial Activity. Mol. Pharm. 2016, 13, 2318-2331. [CrossRef] [PubMed]

73. Tupal, A.; Sabzichi, M.; Ramezani, F.; Kouhsoltani, M.; Hamishehkar, H. Dermal delivery of doxorubicin-loaded solid lipid nanoparticles for the treatment of skin cancer. J. Microencapsul. 2016, 33, 372-380. [CrossRef]

74. Bharadwaj, R.; Das, P.J.; Pal, P.; Mazumder, B. Topical delivery of paclitaxel for treatment of skin cancer. Drug Dev. Ind. Pharm. 2016, 42, 1482-1494. [CrossRef] [PubMed]

75. Hamishehkar, H.; Ghanbarzadeh, S.; Sepehran, S.; Javadzadeh, Y.; Adib, Z.M.; Kouhsoltani, M. Histological assessment of follicular delivery of flutamide by solid lipid nanoparticles: Potential tool for the treatment of androgenic alopecia. Drug Dev. Ind. Pharm. 2015, 42, 846-853. [CrossRef] [PubMed]

76. Pradhan, M.; Singh, D.; Singh, M.R. Influence of selected variables on fabrication of Triamcinolone acetonide loaded solid lipid nanoparticles for topical treatment of dermal disorders. Artif. Cells Nanomed. Biotechnol. 2016, 44, 392-400. [CrossRef]

77. Raj, R.; Mongia, P.; Ram, A.; Jain, N.K. Enhanced skin delivery of aceclofenac via hydrogel-based solid lipid nanoparticles. Artif. Cells Nanomed. Biotechnol. 2015, 44, 1434-1439. [CrossRef]

78. Garcia-Orue, I.; Gainza, G.; Girbau, C.; Alonso, R.; Aguirre, J.J.; Pedraz, J.L.; Igartua, M.; Hernandez, R.M. LL37 loaded nanostructured lipid carriers (NLC): A new strategy for the topical treatment of chronic wounds. Eur. J. Pharm. Biopharm. 2016, 108, 310-316. [CrossRef] 
79. Jain, A.; Garg, N.K.; Jain, A.; Kesharwani, P.; Jain, A.K.; Nirbhavane, P.; Tyagi, R.K. A synergistic approach of adapa-lene-loaded nanostructured lipid carriers, and vitamin C co-administration for treating acne. Drug Dev. Ind. Pharm. 2016, 42, 897-905. [CrossRef]

80. Lewies, A.; Wentzel, J.F.; Jordaan, A.; Bezuidenhout, C.; Du Plessis, L.H. Interactions of the antimicrobial peptide nisin Z with conventional antibiotics and the use of nanostructured lipid carriers to enhance antimicrobial activity. Int. J. Pharm. 2017, 526, 244-253. [CrossRef]

81. You, P.; Yuan, R.; Chen, C. Design and evaluation of lidocaine- and prilocaine-coloaded nanoparticulate drug delivery sys-tems for topical anesthetic analgesic therapy: A comparison between solid lipid nanoparticles and nanostructured lipid car-riers. Drug Des. Dev. Ther. 2017, 11, 2743-2752. [CrossRef]

82. Bhalekar, M.R.; Madgulkar, A.R.; Desale, P.S.; Marium, G. Formulation of piperine solid lipid nanoparticles (SLN) for treatment of rheumatoid arthritis. Drug Dev. Ind. Pharm. 2017, 43, 1003-1010. [CrossRef]

83. Rosseto, H.C.; Toledo, L.D.A.S.D.; De Francisco, L.M.B.; Esposito, E.; Lim, Y.; Valacchi, G.; Cortesi, R.; Bruschi, M.L. Nanostructured lipid systems modified with waste material of propolis for wound healing: Design, in vitro and in vivo evaluation. Colloids Surf. B Biointerfaces 2017, 158, 441-452. [CrossRef] [PubMed]

84. Peng, L.-H.; Wei, W.; Shan, Y.-H.; Chong, Y.-S.; Yu, L.; Gao, J.-Q. Sustained release of piroxicam from solid lipid nanoparti-cle as an effective anti-inflammatory therapeutics in vivo. Drug Dev. Ind. Pharm. 2017, 43, 55-66. [CrossRef] [PubMed]

85. Wang, W.; Chen, L.; Huang, X.; Shao, A. Preparation and Characterization of Minoxidil Loaded Nanostructured Lipid Car-riers. AAPS PharmSciTech 2017, 18, 509-516. [CrossRef] [PubMed]

86. Shrotriya, S.N.; Vidhate, B.V.; Shukla, M.S. Formulation and development of Silybin loaded solid lipid nanoparticle en-riched gel for irritant contact dermatitis. J. Drug Deliv. Sci. Technol. 2017, 41, 164-173. [CrossRef]

87. Carbone, C.; Martins-Gomes, C.; Pepe, V.; Silva, A.M.; Musumeci, T.; Puglisi, G.; Furneri, P.M.; Souto, E.B. Repurposing itraconazole to the benefit of skin cancer treatment: A combined azole-DDAB nanoencapsulation strategy. Colloids Surf. B Biointerfaces 2018, 167, 337-344. [CrossRef]

88. Zhao, X.; Sun, Y.; Li, Z. Topical anesthesia therapy using lidocaine-loaded nanostructured lipid carriers: Tocopheryl poly-ethylene glycol 1000 succinate-modified transdermal delivery system. Drug Des. Dev. Ther. 2018, 12, 4231-4240. [CrossRef] [PubMed]

89. Kaur, N.; Sharma, K.; Bedi, N. Topical Nanostructured Lipid Carrier Based Hydrogel of Mometasone Furoate for the Treatment of Psoriasis. Pharm. Nanotechnol. 2018, 6, 133-143. [CrossRef]

90. Rostamkalaei, S.S.; Akbari, J.; Saeedi, M.; Morteza-Semnani, K.; Nokhodchi, A. Topical gel of Metformin solid lipid na-noparticles: A hopeful promise as a dermal delivery system. Colloids Surf. B Biointerfaces 2019, 175, 150-157. [CrossRef]

91. Bagde, A.; Patel, K.; Kutlehria, S.; Chowdhury, N.; Singh, M. Formulation of topical ibuprofen solid lipid nanoparticle (SLN) gel using hot melt extrusion technique (HME) and determining its anti-inflammatory strength. Drug Deliv. Transl. Res. 2019, 9, 816-827. [CrossRef]

92. Mendes, I.; Ruela, A.; Carvalho, F.; Freitas, J.; Bonfilio, R.; Pereira, G. Development and characterization of nanostructured lipid carrier-based gels for the transdermal delivery of donepezil. Colloids Surf. B Biointerfaces 2019, 177, 274-281. [CrossRef] [PubMed]

93. Waghule, T.; Rapalli, V.K.; Singhvi, G.; Manchanda, P.; Hans, N.; Dubey, S.K.; Hasnain, M.S.; Nayak, A.K. Voriconazole loaded nanostructured lipid carriers based topical delivery system: QbD based designing, characterization, in-vitro and ex-vivo evaluation. J. Drug Deliv. Sci. Technol. 2019, 52, 303-315. [CrossRef]

94. Montenegro, L.; Panico, A.M.; Santagati, L.M.; Siciliano, E.A.; Intagliata, S.; Modica, M.N. Solid Lipid Nanoparticles Loading Idebenone Ester with Pyroglutamic Acid: In Vitro Antioxidant Activity and In Vivo Topical Efficacy. Nanomaterials 2018, 9, 43. [CrossRef] [PubMed]

95. Aland, R.; Ganesan, M.; Rajeswara, R.P. Development and optimization of tazarotene loaded solid lipid nanoparticles for topical delivery. Asian J. Pharm. Clin. Res. 2019, 12, 63-77. [CrossRef]

96. Khezri, K.; Farahpour, M.R.; Rad, S.M. Accelerated infected wound healing by topical application of encapsulated Rosemary essential oil into nanostructured lipid carriers. Artif. Cells Nanomed. Biotechnol. 2019, 47, 980-988. [CrossRef]

97. Sathe, P.; Saka, R.; Kommineni, N.; Raza, K.; Khan, W. Dithranol-loaded nanostructured lipid carrier-based gel amelio-rate psoriasis in imiquimod-induced mice psoriatic plaque model. Drug Dev. Ind. Pharm. 2019, 45, 826-838. [CrossRef] [PubMed]

98. Ghodrati, M.; Farahpour, M.R.; Hamishehkar, H. Encapsulation of Peppermint essential oil in nanostructured lipid car-riers: In-vitro antibacterial activity and accelerative effect on infected wound healing. Colloids Surf. A Phys. Chem. Eng. Asp. 2019, 564, 161-169. [CrossRef]

99. Gu, Y.; Tang, X.; Yang, M.; Yang, D.; Liu, J. Transdermal drug delivery of triptolide-loaded nanostructured lipid carriers: Preparation, pharmacokinetic, and evaluation for rheumatoid arthritis. Int. J. Pharm. 2019, 554, 235-244. [CrossRef]

100. Souto, E.B.; Zielinska, A.; Souto, S.B.; Durazzo, A.; Lucarini, M.; Santini, A.; Silva, A.M.; Atanasov, A.G.; Marques, C.; Andrade, L.N.; et al. (+)-Limonene 1,2-Epoxide-Loaded SLNs: Evaluation of Drug Release, Antioxidant Activity, and Cytotoxicity in an HaCaT Cell Line. Int. J. Mol. Sci. 2020, 21, 1449. [CrossRef]

101. Al-Maghrabi, P.M.; Khafagy, E.-S.; Ghorab, M.M.; Gad, S. Influence of formulation variables on miconazole ni-trate-loaded lipid based nanocarrier for topical delivery. Colloids Surf. B Biointerfaces 2020, 193, 111046. [CrossRef]

102. Mohammadi-Samani, S.; Salehi, H.; Entezar-Almahdi, E.; Masjedi, M. Preparation and characterization of sumatriptan loaded solid lipid nanoparticles for transdermal delivery. J. Drug Deliv. Sci. Technol. 2020, 57, 101719. [CrossRef] 
103. Dudhipala, N.; Gorre, T. Neuroprotective Effect of Ropinirole Lipid Nanoparticles Enriched Hydrogel for Parkinson's Disease: In Vitro, Ex Vivo, Pharmacokinetic and Pharmacodynamic Evaluation. Pharmaceutics 2020, 12, 448. [CrossRef] [PubMed]

104. Anantaworasakul, P.; Chaiyana, W.; Michniak-Kohn, B.B.; Rungseevijitprapa, W.; Ampasavate, C. Enhanced Transder-mal Delivery of Concentrated Capsaicin from Chili Extract-Loaded Lipid Nanoparticles with Reduced Skin Irritation. Pharmaceutics 2020, 12, 463. [CrossRef]

105. Madan, J.R.; Khobaragade, S.; Dua, K.; Awasthi, R. Formulation, optimization, and in vitro evaluation of nanostruc-tured lipid carriers for topical delivery of Apremilast. Dermatol. Ther. 2020, e13370.

106. Passos, J.S.; De Martino, L.C.; Dartora, V.F.C.; De Araujo, G.L.B.; Ishida, K.; Lopes, L.B. Development, skin targeting and antifungal efficacy of topical lipid nanoparticles containing itraconazole. Eur. J. Pharm. Sci. 2020, 149, 105296. [CrossRef] [PubMed]

107. Carvajal-Vidal, P.; González-Pizarro, R.; Araya, C.; Espina, M.; Halbaut, L.; Gómez de Aranda, I.; García, M.L.; Calpena, A.C. Nanostructured lipid carriers loaded with Halobetasol propionate for topical treatment of inflammation: Devel-opment, characterization, biopharmaceutical behavior and therapeutic efficacy of gel dosage forms. Int. J. Pharm. 2020, 585, 119480. [CrossRef]

108. Viegas, J.S.R.; Praça, F.G.; Caron, A.L.; Suzuki, I.; Silvestrini, A.V.P.; Medina, W.S.G.; Del Ciampo, J.O.; Kravicz, M.; Bentley, M.V.L.B. Nanostructured lipid carrier co-delivering tacrolimus and TNF- $\alpha$ siRNA as an innovate approach to psoriasis. Drug Deliv. Transl. Res. 2020, 10, 646-660. [CrossRef]

109. Nagaich, U.; Gulati, N. Nanostructured lipid carriers (NLC) based controlled release topical gel of clobetasol propio-nate: Design and in vivo characterization. Drug Deliv. Transl. Res. 2016, 6, 289-298. [CrossRef]

110. Bhalekar, M.; Upadhaya, P.; Madgulkar, A. Formulation and evaluation of Adapalene-loaded nanoparticulates for epi-dermal localization. Drug Deliv. Transl. Res. 2015, 5, 585-595. [CrossRef] [PubMed]

111. Silva, E.L.; Carneiro, G.; De Araújo, L.A.; De Jesus, M.; Trindade, V.; Yoshida, M.I.; Oréfice, R.L.; Farias, L.D.M.; De Carvalho, M.A.R.; Dos Santos, S.G.; et al. Solid Lipid Nanoparticles Loaded with Retinoic Acid and Lauric Acid as an Alternative for Topical Treatment of Acne Vulgaris. J. Nanosci. Nanotechnol. 2015, 15, 792-799. [CrossRef]

112. Gupta, S.; Wairkar, S.; Bhatt, L.K. Isotretinoin and $\alpha$-tocopherol acetate-loaded solid lipid nanoparticle topical gel for the treatment of acne. J. Microencapsul. 2020, 37, 1-9. [CrossRef] [PubMed]

113. Kelidari, H.R.; Saeedi, M.; Hajheydari, Z.; Akbari, J.; Morteza-Semnani, K.; Akhtari, J.; Valizadeh, H.; Asare-Addo, K.; Nokhodchi, A. Spironolactone loaded nanostructured lipid carrier gel for effective treatment of mild and moderate ac-ne vulgaris: A randomized, double-blind, prospective trial. Colloids Surf. B Biointerfaces 2016, 146, 47-53. [CrossRef] [PubMed]

114. Abdel-Salam, F.S.; Mahmoud, A.A.; Ammar, H.O.; Elkheshen, S.A. Nanostructured lipid carriers as semisolid topical delivery formulations for diflucortolone valerate. J. Liposome Res. 2016, 27, 41-55. [CrossRef] [PubMed]

115. Yong-Tai, Z.; Meng-Qing, H.; Li-Na, S.; Ji-Hui, Z.; Nian-Ping, F. Solid Lipid Nanoparticles Formulated for Transdermal Aconitine Administration and Evaluated In Vitro and In Vivo. J. Biomed. Nanotechnol. 2015, 11, 351-361. [CrossRef]

116. Kurakula, M.; Ahmad, O.A.A.; Fahmy, U.A.; Ahmed, T.A. Solid lipid nanoparticles for transdermal delivery of avanafil: Optimization, formulation, in-vitro and ex-vivo studies. J. Liposome Res. 2016, 26, 288-296. [CrossRef]

117. Joshi, S.A.; Jalalpure, S.S.; Kempwade, A.A.; Peram, M.R. Fabrication and in-vivo evaluation of lipid nanocarriers based transdermal patch of colchicine. J. Drug Deliv. Sci. Technol. 2017, 41, 444-453. [CrossRef]

118. Lee, M.H.; Shin, G.H.; Park, H.J. Solid lipid nanoparticles loaded thermoresponsive pluronic-xanthan gum hydrogel as a transdermal delivery system. J. Appl. Polym. Sci. 2018, 135, 46004. [CrossRef]

119. Guo, D.; Dou, D.; Li, X.; Zhang, Q.; Bhutto, Z.A.; Wang, L. Ivermection-loaded solid lipid nanoparticles: Preparation, characterisation, stability and transdermal behaviour. Artif. Cells Nanomed. Biotechnol. 2018, 46, 255-262. [CrossRef]

120. Yue, Y.; Zhao, D.; Yin, Q. Hyaluronic acid modified nanostructured lipid carriers for transdermal bupivacaine delivery: In vitro and in vivo anesthesia evaluation. Biomed. Pharmacother. 2018, 98, 813-820. [CrossRef]

121. Nguyen, C.N.; Nguyen, T.T.T.; Nguyen, H.T.; Tran, T.H. Nanostructured lipid carriers to enhance transdermal delivery and efficacy of diclofenac. Drug Deliv. Transl. Res. 2017, 7, 664-673. [CrossRef]

122. Chauhan, M.K.; Sharma, P.K. Optimization and characterization of rivastigmine nanolipid carrier loaded transdermal patches for the treatment of dementia. Chem. Phys. Lipids 2019, 224, 104794. [CrossRef]

123. Chen, H.; Wang, Y.; Zhai, Y.; Zhai, G.; Wang, Z.; Liu, J. Development of a ropivacaine-loaded nanostructured lipid car-rier formulation for transdermal delivery. Colloids Surf. A Physicochem. Eng. Asp. 2015, 465, 130-136. [CrossRef]

124. Gaur, P.K.; Mishra, S.; Verma, A.; Verma, N. Ceramide-palmitic acid complex based Curcumin solid lipid nanoparticles for transdermal delivery: Pharmacokinetic and pharmacodynamic study. J. Exp. Nanosci. 2015, 11, 38-53. [CrossRef]

125. Baek, J.-S.; Pham, C.V.; Myung, C.-S.; Cho, C.-W. Tadalafil-loaded nanostructured lipid carriers using permeation en-hancers. Int. J. Pharm. 2015, 495, 701-709. [CrossRef]

126. Garg, N.K.; Singh, B.; Tyagi, R.K.; Sharma, G.; Katare, O.P. Effective transdermal delivery of methotrexate through nanostructured lipid carriers in an experimentally induced arthritis model. Colloids Surf. B Biointerfaces 2016, 147, 17-24. [CrossRef]

127. Garg, N.K.; Sharma, G.; Singh, B.; Nirbhavane, P.; Tyagi, R.K.; Shukla, R.; Katare, O. Quality by Design (QbD)-enabled development of aceclofenac loaded-nano structured lipid carriers (NLCs): An improved dermatokinetic profile for in-flammatory disorder (s). Int. J. Pharm. 2017, 517, 413-431. [CrossRef]

128. Akbarzadeh, A.; Rezaei-Sadabady, R.; Davaran, S.; Joo, S.W.; Zarghami, N.; Hanifehpour, Y.; Samiei, M.; Kouhi, M.; Nejati-Koshki, K. Liposome: Classification, preparation, and applications. Nanoscale Res. Lett. 2013, 8, 102. [CrossRef] [PubMed] 
129. Pauli, G.; Tang, W.-L.; Li, S.-D. Development and Characterization of the Solvent-Assisted Active Loading Technology (SALT) for Liposomal Loading of Poorly Water-Soluble Compounds. Pharmaceutics 2019, 11, 465. [CrossRef] [PubMed]

130. Rovira-Bru, M.; Thompson, D.H.; Szleifer, I. Size and Structure of Spontaneously Forming Liposomes in Li-pid/PEG-Lipid Mixtures. Biophys. J. 2002, 83, 2419-2439. [CrossRef]

131. Mezei, M.; Gulasekharam, V. Liposomes-A selective drug delivery system for the topical route of administration I. Lotion dosage form. Life Sci. 1980, 26, 1473-1477. [CrossRef]

132. Touitou, E.; Junginger, H.E.; Weiner, N.D.; Nagai, T.; Mezei, M. Liposomes as carriers for topical and transdermal de-livery. J. Pharm. Sci. 1994, 83, 1189-1203. [CrossRef]

133. Pierre, M.B.R.; Costa, I.D.S.M. Liposomal systems as drug delivery vehicles for dermal and transdermal applications. Arch. Dermatol. Res. 2011, 303, 607-621. [CrossRef] [PubMed]

134. Yatvin, M.B.; Lelkes, P.I. Clinical prospects for liposomes. Med. Phys. 1982, 9, 149-175. [CrossRef]

135. Pathak, Y.; Thassu, D. Drug Delivery Nanoparticles Formulation and Characterization; CRC Press: Boca Raton, FL, USA, 2009 ; p. 416.

136. Hua, S. Lipid-based nano-delivery systems for skin delivery of drugs and bioactives. Front. Pharmacol. 2015, 6, 219. [CrossRef] [PubMed]

137. Cevc, G.; Blume, G. Lipid vesicles penetrate into intact skin owing to the transdermal osmotic gradients and hydration force. Biochim. Biophys. Acta (BBA) Biomembr. 1992, 1104, 226-232. [CrossRef]

138. El Maghraby, G.M.M.; Williams, A.C.; Barry, B.W. Skin delivery of estradiol from lipid vesicles: Importance of lipo-some structure. Int. J. Pharm. 2000, 204, 159-169. [CrossRef]

139. Maghraby, G.M.M.E.; Williams, A.C.; Barry, B.W. Skin hydration and possible shunt route penetration in controlled estradiol delivery from ultradeformable and standard liposomes. J. Pharm. Pharmacol. 2001, 53, 1311-1322. [CrossRef] [PubMed]

140. Natsheh, H.; Touitou, E. Phospholipid Vesicles for Dermal/Transdermal and Nasal Administration of Active Molecules: The Effect of Surfactants and Alcohols on the Fluidity of Their Lipid Bilayers and Penetration Enhancement Properties. Molecules 2020, 25, 2959. [CrossRef]

141. Elsayed, M.A.; Abdallah, O.Y.; Naggar, V.F.; Khalafallah, N.M. Lipid vesicles for skin delivery of drugs: Reviewing three decades of research. Int. J. Pharm. 2007, 332, 1-16. [CrossRef]

142. Ghanbarzadeh, S.; Arami, S. Enhanced Transdermal Delivery of Diclofenac Sodium via Conventional Liposomes, Ethosomes, and Transfersomes. BioMed Res. Int. 2013, 2013, 1-7. [CrossRef]

143. Zhao, Y.-Z.; Lu, C.-T.; Zhang, Y.; Xiao, J.; Zhao, Y.-P.; Tian, J.-L.; Xu, Y.-Y.; Feng, Z.-G.; Xu, C.-Y. Selection of high effi-cient transdermal lipid vesicle for curcumin skin delivery. Int. J. Pharm. 2013, 454, 302-309. [CrossRef]

144. Opatha, S.A.T.; Titapiwatanakun, V.; Chutoprapat, R. Transfersomes: A Promising Nanoencapsulation Technique for Transdermal Drug Delivery. Pharmaceutics 2020, 12, 855. [CrossRef] [PubMed]

145. Touitou, E. Compositions for applying active substances to or through the skin, United states patent. US patent 5,716,638, 10 February 1998.

146. Fang, Y.-P.; Huang, Y.-B.; Wu, P.-C.; Tsai, Y.-H. Topical delivery of 5-aminolevulinic acid-encapsulated ethosomes in a hyperproliferative skin animal model using the CLSM technique to evaluate the penetration behavior. Eur. J. Pharm. Biopharm. 2009, 73, 391-398. [CrossRef] [PubMed]

147. Godin, B.; Touitou, E. Mechanism of bacitracin permeation enhancement through the skin and cellular membranes from an ethosomal carrier. J. Control. Release 2004, 94, 365-379. [CrossRef] [PubMed]

148. Verma, P.; Pathak, K. Therapeutic and cosmeceutical potential of ethosomes: An overview. J. Adv. Pharm. Technol. Res. 2010, 1, 274-282. [CrossRef]

149. Touitou, E.; Dayan, N.; Bergelson, L.; Godin, B.; Eliaz, M. Ethosomes-Novel vesicular carriers for enhanced delivery: Characterization and skin penetration properties. J. Control. Release 2000, 65, 403-418. [CrossRef]

150. Ainbinder, D.; Touitou, E. Testosterone Ethosomes for Enhanced Transdermal Delivery. Drug Deliv. 2005, 12, 297-303. [CrossRef]

151. Zailer, J.; Touitou, E. Pouch drug delivery systems for dermal and transdermal administration. Drug Deliv. Transl. Res. 2014, 4, 416-428. [CrossRef]

152. Bhalaria, M.K.; Naik, S.; Misra, A.N. Ethosomes: A novel delivery system for antifungal drugs in the treatment of topi-cal fungal diseases. Indian J. Exp. Biol. 2009, 47, 368-375.

153. Paolino, D.; Celia, C.; Trapasso, E.; Cilurzo, F.; Fresta, M. Paclitaxel-loaded ethosomes ${ }^{\circledR}$ : Potential treatment of squamous cell carcinoma, a malignant transformation of actinic keratoses. Eur. J. Pharm. Biopharm. 2012, 81, 102-112. [CrossRef]

154. Dubey, V.; Mishra, D.; Dutta, T.; Nahar, M.; Saraf, D.; Jain, N. Dermal and transdermal delivery of an anti-psoriatic agent via ethanolic liposomes. J. Control. Release 2007, 123, 148-154. [CrossRef] [PubMed]

155. Marianecci, C.; Di Marzio, L.; Rinaldi, F.; Celia, C.; Paolino, D.; Alhaique, F.; Esposito, S.; Carafa, M. Niosomes from 80s to present: The state of the art. Adv. Colloid Interface Sci. 2014, 205, 187-206. [CrossRef]

156. Uchegbu, I.F.; Schätzlein, A.; Vanlerberghe, G.; Morgatini, N.; Florence, A.T. Polyhedral Non-ionic Surfactant Vesicles. J. Pharm. Pharmacol. 1997, 49, 606-610. [CrossRef]

157. Jain, S.; Jain, V.; Mahajan, S.C. Lipid Based Vesicular Drug Delivery Systems. Adv. Pharm. 2014, 2014, 1-12. [CrossRef]

158. Kotla, N.G.; Chandrasekar, B.; Rooney, P.; Sivaraman, G.; Larrañaga, A.; Krishna, K.V.; Pandit, A.; Rochev, Y. Biomi-metic LipidBased Nanosystems for Enhanced Dermal Delivery of Drugs and Bioactive Agents. ACS Biomater. Sci. Eng. 2017, 3, 1262-1272. [CrossRef] 
159. Karami, Z.; Hamidi, M. Cubosomes: Remarkable drug delivery potential. Drug Discov. Today 2016, 21, 789-801. [CrossRef] [PubMed]

160. Duarah, S.; Durai, R.D.; Narayanan, V.B. Nanoparticle-in-gel system for delivery of vitamin C for topical application. Drug Deliv. Transl. Res. 2017, 7, 750-760. [CrossRef]

161. Esposito, E.; Eblovi, N.; Rasi, S.; Drechsler, M.; Di Gregorio, G.M.; Menegatti, E.; Cortesi, R. Lipid-based supramolecular systems for topical application: A preformulatory study. AAPS PharmSci 2003, 5, 62-76. [CrossRef]

162. Amar-Yuli, I.; Wachtel, E.; Ben Shoshan, E.; Danino, D.; Aserin, A.A.; Garti, N. Hexosome and Hexagonal Phases Mediated by Hydration and Polymeric Stabilizer. Langmuir 2007, 23, 3637-3645. [CrossRef]

163. Azmi, I.D.M.; Moghimi, S.M.; Yaghmur, A. Cubosomes and hexosomes as versatile platforms for drug delivery. Ther. Deliv. 2015, 6, 1347-1364. [CrossRef]

164. Yaghmur, A.; Mu, H. Recent advances in drug delivery applications of cubosomes, hexosomes, and solid lipid nanoparticles. Acta Pharm. Sin. B 2021. [CrossRef]

165. Fornasier, M.; Pireddu, R.; Del Giudice, A.; Sinico, C.; Nylander, T.; Schillén, K.; Galantini, L.; Murgia, S. Tuning lipid structure by bile salts: Hexosomes for topical administration of catechin. Colloids Surf. B Biointerfaces 2021, 199, 111564. [CrossRef]

166. Gururaj, S.S.; Ashok, V.B.; Swati, S.M.; Nilesh, R.B.; Prashant, H.K.; Nishant, P.K.; Sagar, T. An overview on nanocarrier technologyAquasomes. J. Pharm. Res. 2009, 2, 1174-1177.

167. Lee, D.; Weitz, D.A. Double Emulsion-Templated Nanoparticle Colloidosomes with Selective Permeability. Adv. Mater. 2008, 20, 3498-3503. [CrossRef]

168. Saraf, S.; Gupta, D.; Kaur, C.D.; Saraf, S. Sphingosomes a novel approach to ve-sicular drug delivery. Int. J. Cur. Sci. Res. 2011, 1,63-68.

169. Jadhav, S.M.; Morey, P.; Karpe, M.M.; Kadam, V. Novel vesicular system: An overview. J. Appl. Pharm. Sci. $2012,2,193-202$.

170. Patel, D.M.; Patel, C.N.; Jani, R.H. Ufasomes: A vesicular drug delivery. Syst. Rev. Pharm. 2011, 2, 72. [CrossRef]

171. Naik, P.V.; Dixit, S.G. Ufasomes as Plausible Carriers for Horizontal Gene Transfer. J. Dispers. Sci. Technol. 2008, $29,804-808$. [CrossRef]

172. Gebicki, J.; Hicks, M. Preparation and properties of vesicles enclosed by fatty acid membranes. Chem. Phys. Lipids 1976, 16, 142-160. [CrossRef]

173. Cosco, D.; Paolino, D.; Maiuolo, J.; Di Marzio, L.; Carafa, M.; Ventura, C.A.; Fresta, M. Ultradeformable liposomes as multidrug carrier of resveratrol and 5-fluorouracil for their topical delivery. Int. J. Pharm. 2015, 489, 1-10. [CrossRef]

174. Jiang, T.; Wang, T.; Li, T.; Ma, Y.; Shen, S.; He, B.; Mo, R. Enhanced Transdermal Drug Delivery by Transfer-some-Embedded Oligopeptide Hydrogel for Topical Chemotherapy of Melanoma. ACS Nano 2018, 12, 9693-9701. [CrossRef]

175. Cristiano, M.C.; Froiio, F.; Spaccapelo, R.; Mancuso, A.; Nisticò, S.P.; Udongo, B.P.; Fresta, M.; Paolino, D. Sul-foraphane-Loaded Ultradeformable Vesicles as A Potential Natural Nanomedicine for the Treatment of Skin Cancer Diseases. Pharmaceutics 2020, 12, 6. [CrossRef]

176. Abdelbary, A.A.; AbouGhaly, M.H. Design and optimization of topical methotrexate loaded niosomes for enhanced management of psoriasis: Application of Box-Behnken design, in-vitro evaluation and in-vivo skin deposition study. Int. J. Pharm. 2015, 485, 235-243. [CrossRef]

177. Babaie, S.; Ghanbarzadeh, S.; Davaran, S.; Kouhsoltani, M.; Hamishehkar, H. Nanoethosomes for Dermal Delivery of Lidocaine. Adv. Pharm. Bull. 2015, 5, 549-556. [CrossRef]

178. Perez, A.P.; Altube, M.J.; Schilrreff, P.; Apezteguia, G.; Celes, F.S.; Zacchino, S.; de Oliveira, C.I.; Romero, E.L.; Morilla, M.J. Topical amphotericin B in ultradeformable liposomes: Formulation, skin penetration study, antifungal and antileishmanial activity in vitro. Colloids Surf. B Biointerfaces 2016, 139, 190-198. [CrossRef]

179. Garg, B.J.; Garg, N.K.; Beg, S.; Singh, B.; Katare, O.P. Nanosized ethosomes-based hydrogel formulations of methox-salen for enhanced topical delivery against vitiligo: Formulation optimization, in vitro evaluation and preclinical as-sessment. J. Drug Target. 2016, 24, 233-246. [CrossRef] [PubMed]

180. Godin, B.; Touitou, E.; Rubinstein, E.; Athamna, A.; Athamna, M. A new approach for treatment of deep skin infections by an ethosomal antibiotic preparation: An in vivo study. J. Antimicrob. Chemother. 2005, 55, 989-994. [CrossRef]

181. Godin, B.; Touitou, E. Erythromycin ethosomal systems: Physicochemical characterization and enhanced antibacterial activity. Curr. Drug Deliv. 2005, 2, 269-275. [CrossRef] [PubMed]

182. Zahid, S.R.; Dangi, S.; Shende, S.M.; Upmanyu, N. Formulation and evaluation of clindamycin phosphate ethosomal gel. World J. Pharm. Pharm. Sci. 2020, 9, 1804-1813.

183. Schaeffer, H.J.; Beauchamp, L.; de Miranda, P.; Elion, G.B.; Bauer, D.J.; Collins, P. 9-(2-Hydroxyethoxymethyl)guanine activity against viruses of the herpes group. Nature 1978, 272, 583-585. [CrossRef] [PubMed]

184. Horwitz, E.; Pisanty, S.; Czerninski, R.; Helser, M.; Eliav, E.; Touitou, E. A clinical evaluation of a novel liposomal carrier for acyclovir in the topical treatment of recurrent herpes labialis. Oral Surg. Oral Med. Oral Pathol. Oral Radiol. Endodontol. 1999, 87, 700-705. [CrossRef]

185. Shukla, K.V.; Sharma, A.; Yadav, M. Formulation development and evaluation of ethosomal gel of acyclovir for the treatment of herpes zoster. J. Nanosci. Nanotechnol. 2019, 9 (Suppl. 2), 664-668. 
186. Touitou, E.; Godin, B.; Shumilov, M.; Bishouty, N.; Ainbinder, D.; Shouval, R.; Ingber, A.; Leibovici, V. Efficacy and tolerability of clindamycin phosphate and salicylic acid gel in the treatment of mild to moderate acne vulgaris. J. Eur. Acad. Dermatol. Venereol. 2008, 22, 629-631. [CrossRef]

187. Gollnick, H.P.; Krautheim, A. Topical treatment in acne: Current status and future aspects. Dermatology 2003, 206, 29-36. [CrossRef]

188. Apriani, E.F.; Rosana, Y.; Iskandarsyah, I. Formulation, characterization, and in vitro testing of azelaic acid ethosome-based cream against Propionibacterium acnes for the treatment of acne. J. Adv. Pharm. Technol. Res. 2019, 10, 75.

189. Lodzki, M.; Godin, B.; Rakou, L.; Mechoulam, R.; Gallily, R.; Touitou, E. Cannabidiol—transdermal delivery and anti-inflammatory effect in a murine model. J. Control Release 2003, 93, 377-387. [CrossRef]

190. Shumilov, M.; Touitou, E. Buspirone transdermal administration for menopausal syndromes, in vitro and in animal model studies. Int. J. Pharm. 2010, 387, 26-33. [CrossRef]

191. Shuwaili, A.H.A.; Rasool, B.K.A.; Abdulrasool, A.A. Optimization of elastic transfersomes formulations for transdermal delivery of pentoxifylline. Eur. J. Pharm. Biopharm. 2016, 102, 101-114. [CrossRef] [PubMed]

192. Qumbar, M.; Ameeduzzafar; Imam, S.S.; Ali, J.; Ahmad, J.; Ali, A. Formulation and optimization of lacidipine loaded niosomal gel for transdermal delivery: In-vitro characterization and in-vivo activity. Biomed. Pharmacother. 2017, 93, 255-266. [CrossRef]

193. Pando, D.; Matos, M.; Gutierrez, G.; Pazos, C. Formulation of resveratrol entrapped niosomes for topical use. Colloids Surf. B Biointerfaces 2015, 128, 398-404. [CrossRef] [PubMed]

194. Goyal, G.; Garg, T.; Malik, B.; Chauhan, G.; Rath, G.; Goyal, A.K. Development and characterization of niosomal gel for topical delivery of benzoyl peroxide. Drug Deliv. 2015, 22, 1027-1042. [CrossRef]

195. Gupta, A.; Singh, S.; Kotla, N.G.; Webster, T.J. Formulation and evaluation of a topical niosomal gel containing a combination of benzoyl peroxide and tretinoin for antiacne activity. Int. J. Nanomed. 2015, 10, 171-182.

196. Choi, J.-H.; Cho, S.-H.; Yun, J.-J.; Yu, Y.-B.; Cho, C.-W. Ethosomes and transfersomes for topical delivery of ginsenoside Rh1 from red ginseng: Characterization and in vitro evaluation. J. Nanosci. Nanotechnol. 2015, 15, 5660-5662. [CrossRef]

197. Sarwa, K.K.; Mazumder, B.; Rudrapal, M.; Verma, V.K. Potential of capsaicin-loaded transfersomes in arthritic rats. Drug Deliv. 2015, 22, 638-646. [CrossRef]

198. Fadel, M.; Kassab, K.; Samy, N.; Thabet, S. Indocyanine green transferosomal hydrogel with enhanced stability and skin permeation for treatment of acne vulgaris: (in-vitro and clinical study). Eur. J. Biomed. Pharm. Sci. 2015, 2, $20-36$.

199. Gu, J.; Mao, X.; Li, C.; Ao, H.; Yang, X. A Novel Therapy for Laryngotracheal Stenosis: Treatment With Ethosomes Containing 5-Fluorouracil. Ann. Otol. Rhinol. Laryngol. 2015, 124, 561-566. [CrossRef]

200. Castangia, I.; Caddeo, C.; Manca, M.L.; Casu, L.; Latorre, A.C.; Diez-Sales, O.; Ruiz-Sauri, A.; Bacchetta, G.; Fadda, A.M.; Manconi, M. Delivery of liquorice extract by liposomes and hyalurosomes to protect the skin against oxidative stress injuries. Carbohydr. Polym. 2015, 134, 657-663. [CrossRef]

201. Khan, M.A.; Pandit, J.; Sultana, Y.; Sultana, S.; Ali, A.; Aqil, M.; Chauhan, M. Novel carbopol-based transfersomal gel of 5-fluorouracil for skin cancer treatment: In vitro characterization and in vivo study. Drug Deliv. 2015, 22, 795-802. [CrossRef] [PubMed]

202. Moghddam, S.R.M.; Ahad, A.; Aqil, M.; Imam, S.S.; Sultana, Y. Formulation and optimization of niosomes for topical diacerein delivery using 3-factor, 3-level Box-Behnken design for the management of psoriasis. Mater. Sci. Eng. C 2016, 69, 789-797. [CrossRef] [PubMed]

203. Caddeo, C.; Nacher, A.; Vassallo, A.; Armentano, M.F.; Pons, R.; Fernandez-Busquets, X.; Carbone, C.; Valenti, D.; Fadda, A.M.; Manconi, M. Effect of quercetin and resveratrol co-incorporated in liposomes against inflammatory/oxidative response associated with skin cancer. Int. J. Pharm. 2016, 513, 153-163. [CrossRef] [PubMed]

204. Dorrani, M.; Garbuzenko, O.B.; Minko, T.; Michniak-Kohn, B. Development of edge-activated liposomes for siRNA delivery to human basal epidermis for melanoma therapy. J. Control. Release 2016, 228, 150-158. [CrossRef]

205. Desmet, E.; Bracke, S.; Forier, K.; Taevernier, L.; Stuart, M.C.A.; De Spiegeleer, B.; Raemdonck, K.; Van Gele, M.; Lambert, J. An elastic liposomal formulation for RNAi-based topical treatment of skin disorders: Proof-of-concept in the treatment of psoriasis. Int. J. Pharm. 2016, 500, 268-274. [CrossRef] [PubMed]

206. Sohrabi, S.; Haeri, A.; Mahboubi, A.; Mortazavi, A.; Dadashzadeh, S. Chitosan gel-embedded moxifloxacin niosomes: An efficient antimicrobial hybrid system for burn infection. Int. J. Biol. Macromol. 2016, 85, 625-633. [CrossRef] [PubMed]

207. Priprem, A.; Janpim, K.; Nualkaew, S.; Mahakunakorn, P. Topical Niosome Gel of Zingiber cassumunar Roxb. Extract for Anti-inflammatory Activity Enhanced Skin Permeation and Stability of Compound D. AAPS PharmSciTech 2016, 17, 631-639. [CrossRef] [PubMed]

208. Shreya, A.B.; Managuli, R.S.; Menon, J.; Kondapalli, L.; Hegde, A.R.; Avadhani, K.; Shetty, P.K.; Amirthalingam, M.; Kalthur, G.; Mutalik, S. Nano-transfersomal formulations for transdermal delivery of asenapine maleate: In vitro and in vivo performance evaluations. J. Liposome Res. 2016, 26, 221-232. [CrossRef] [PubMed]

209. Seidel, E.J.; Rother, M.; Regenspurger, K.; Rother, I. A randomised trial comparing the efficacy and safety of topical ketoprofen in Transfersome $\left({ }^{\circledR}\right)$ gel (IDEA-033) with oral ketoprofen and drug-free ultra-deformable Sequessome ${ }^{\mathrm{TM}}$ vesicles (TDT 064) for the treatment of muscle soreness following exercise. J. Sports Sci. 2016, 34, 88-95. [CrossRef] [PubMed]

210. Marto, J.; Vitor, C.; Guerreiro, A.; Severino, C.; Eleuterio, C.; Ascenso, A.; Simoes, S. Ethosomes for enhanced skin delivery of griseofulvin. Colloids Surf. B Biointerfaces 2016, 146, 616-623. [CrossRef] [PubMed] 
211. Sharma, G.; Goyal, H.; Thakur, K.; Raza, K.; Katare, O.P. Novel elastic membrane vesicles (EMVs) and ethosomes-mediated effective topical delivery of aceclofenac: a new therapeutic approach for pain and inflammation. Drug Deliv. 2016, 23, 3135-3145. [CrossRef]

212. Yu, Z.; Lv, H.; Han, G.; Ma, K. Ethosomes loaded with cryptotanshinone for acne treatment through topical gel formulation. PLoS ONE 2016, 11, e0159967. [CrossRef]

213. Arafa, M.G.; Ayoub, B.M. DOE optimization of nano-based carrier of pregabalin as hydrogel: New therapeutic \& chemometric approaches for controlled drug delivery systems. Sci. Rep. 2017, 7, 41503.

214. Kassem, A.A.; Abd El-Alim, S.H.; Asfour, M.H. Enhancement of 8-methoxypsoralen topical delivery via nanosized niosomal vesicles: Formulation development, in vitro and in vivo evaluation of skin deposition. Int. J. Pharm. 2017, 517, 256-268. [CrossRef] [PubMed]

215. Jacob, S.; Nair, A.B.; Al-Dhubiab, B.E. Preparation and evaluation of niosome gel containing acyclovir for enhanced dermal deposition. J. Liposome Res. 2017, 27, 283-292. [CrossRef] [PubMed]

216. Arya, M.; Tiwari, P.; Tripathi, C.B.; Parashar, P.; Singh, M.; Sinha, P.; Yadav, N.P.; Kaithwas, G.; Gupta, K.P.; Saraf, S.A. Colloidal Vesicular System of Inositol Hexaphosphate to Counteract DMBA Induced Dysregulation of Markers Pertaining to Cellular Proliferation/Differentiation and Inflammation of Epidermal Layer in Mouse Model. Mol. Pharm. 2017, 14, 928-939. [CrossRef] [PubMed]

217. Fadel, M.; Samy, N.; Nasr, M.; Alyoussef, A.A. Topical colloidal indocyanine green-mediated photodynamic therapy for treatment of basal cell carcinoma. Pharm. Dev. Technol. 2017, 22, 545-550. [CrossRef] [PubMed]

218. Gupta, M.; Prajapati, R.N.; Irchhaiya, R.; Singh, N.; Prajapati, S.K. Novel clindamycin loaded transfersomes formulation for effective management of acne. World J. Pharm. Res. 2017, 6, 765-773. [CrossRef]

219. Limsuwan, T.; Boonme, P.; Khongkow, P.; Amnuaikit, T. Ethosomes of phenylethyl resorcinol as vesicular delivery system for skin lightening applications. BioMed Res. Int. 2017, 2017. [CrossRef]

220. Priprem, A.; Nukulkit, C.; Johns, N.P.; Laohasiriwong, S.; Yimtae, K.; Soontornpas, C. Transmucosal delivery of melatoninencapsulated niosomes in a mucoadhesive gel. Ther. Deliv. 2018, 9, 343-357. [CrossRef]

221. Dar, M.J.; Din, F.U.; Khan, G.M. Sodium stibogluconate loaded nano-deformable liposomes for topical treatment of leishmaniasis: Macrophage as a target cell. Drug Deliv. 2018, 25, 1595-1606. [CrossRef]

222. Verma, A.; Sharma, G.; Jain, A.; Tiwari, A.; Saraf, S.; Panda, P.K.; Katare, O.P.; Jain, S.K. Systematic optimization of cationic surface engineered mucoadhesive vesicles employing Design of Experiment (DoE): A preclinical investigation. Int. J. Biol. Macromol. 2019, 133, 1142-1155. [CrossRef]

223. Meng, S.; Sun, L.; Wang, L.; Lin, Z.; Liu, Z.; Xi, L.; Wang, Z.; Zheng, Y. Loading of water-insoluble celastrol into niosome hydrogels for improved topical permeation and anti-psoriasis activity. Colloids Surf. B Biointerfaces 2019, 182, 110352. [CrossRef]

224. Van Zyl, L.; Viljoen, J.M.; Haynes, R.K.; Aucamp, M.; Ngwane, A.H.; du Plessis, J. Topical Delivery of Artemisone, Clofazimine and Decoquinate Encapsulated in Vesicles and Their In vitro Efficacy Against Mycobacterium tuberculosis. AAPS PharmSciTech 2019, 20, 1-11. [CrossRef]

225. Omar, M.M.; Hasan, O.A.; El Sisi, A.M. Preparation and optimization of lidocaine transferosomal gel containing permeation enhancers: A promising approach for enhancement of skin permeation. Int. J. Nanomed. 2019, 14, 1551-1562. [CrossRef] [PubMed]

226. Zhang, Y.; Xia, Q.; Li, Y.; He, Z.; Li, Z.; Guo, T.; Wu, Z.; Feng, N. CD44 assists the topical anti-psoriatic efficacy of curcumin-loaded hyaluronan-modified ethosomes: A new strategy for clustering drug in inflammatory skin. Theranostics 2019, 9, 48-64. [CrossRef] [PubMed]

227. El-Kayal, M.; Nasr, M.; Elkheshen, S.; Mortada, N. Colloidal (-)-epigallocatechin-3-gallate vesicular systems for prevention and treatment of skin cancer: A comprehensive experimental study with preclinical investigation. Eur. J. Pharm. Sci. 2019, 137, 104972. [CrossRef] [PubMed]

228. Kausar, H.; Mujeeb, M.; Ahad, A.; Moolakkadath, T.; Aqil, M.; Ahmad, A.; Akhter, H.M. Optimization of ethosomes for topical thymoquinone delivery for the treatment of skin acne. J. Drug Deliv. Sci. Technol. 2019, 49, 177-187. [CrossRef]

229. Dar, M.J.; McElroy, C.A.; Khan, M.I.; Satoskar, A.R.; Khan, G.M. Development and evaluation of novel miltefosine-polyphenol co-loaded second generation nano-transfersomes for the topical treatment of cutaneous leishmaniasis. Expert Opin. Drug Deliv. 2020, 17, 97-110. [CrossRef]

230. Jiang, J.; Ma, T.; Zhang, L.; Cheng, X.; Wang, C. The transdermal performance, pharmacokinetics, and anti-inflammatory pharmacodynamics evaluation of harmine-loaded ethosomes. Drug Dev. Ind. Pharm. 2020, 46, 101-108. [CrossRef]

231. Amr, G.; Sayed, O.M.; Abo El-Ela, F.I.; Kharshoum, R.M.; Salem, H.F. Treatment of Basal Cell Carcinoma Via Binary Ethosomes of Vismodegib: In Vitro and In Vivo Studies. AAPS PharmSciTech 2020, 21, 51.

232. Richa, P.; Kumar, S.D.; Kumar, S.A. Formulation and evaluation of ethosomes of clobetasol propionate. World J. Pharm. Res. 2016, 5, 1183-1197.

233. Rahman, S.A.; Abdelmalak, N.S.; Badawi, A.; Elbayoumy, T.; Sabry, N.; El Ramly, A. Tretinoin-loaded liposomal formulations: From lab to comparative clinical study in acne patients. Drug Deliv. 2016, 23, 1184-1193. [CrossRef]

234. Ingebrigtsen, S.G.; Škalko-Basnet, N.; Jacobsen, C.d.A.C.; Holsæter, A.M. Successful co-encapsulation of benzoyl peroxide and chloramphenicol in liposomes by a novel manufacturing method-dual asymmetric centrifugation. Eur. J. Pharm. Sci. 2017, 97, 192-199. [CrossRef] 
235. Ramkrishna, S.N.; Dharma, H.K.; Choubey, N.; Tyagi, C.K.; Budholiya, P.; Parkhe, G. Formulation and evaluation of liposomal gel for effective treatment of acne. Asian J. Pharm. Educ. Res. 2019, 8, 64-74.

236. Jain, S.; Kale, D.P.; Swami, R.; Katiyar, S.S. Codelivery of benzoyl peroxide \& adapalene using modified liposomal gel for improved acne therapy. Nanomedicine 2018, 13, 1481-1493. [PubMed]

237. Mishra, R.; Shende, S.; Jain, P.K.; Jain, V. Formulation and evaluation of gel containing ethosomes entrapped with tretinoin. J. Drug Deliv. Ther. 2018, 8, 315-321. [CrossRef]

238. Csongradi, C.; Du Plessis, J.; Aucamp, M.E.; Gerber, M. Topical delivery of roxithromycin solid-state forms entrapped in vesicles. Eur. J. Pharm. Biopharm. 2017, 114, 96-107. [CrossRef]

239. Harmita, H.; Iskandarsyah, I.; Afifah, S.F. Effect of transfersome formulation on the stability and antioxidant activity of Nacetylcysteine in anti-aging cream. Int. J. Appl. Pharm. 2020, 12, 156-162. [CrossRef]

240. Mennini, N.; Cirri, M.; Maestrelli, F.; Mura, P. Comparison of liposomal and NLC (nanostructured lipid carrier) formulations for improving the transdermal delivery of oxaprozin: Effect of cyclodextrin complexation. Int. J. Pharm. 2016, 515, 684-691. [CrossRef] [PubMed]

241. Jamal, M.; Imam, S.S.; Aqil, M.; Amir, M.; Mir, S.R.; Mujeeb, M. Transdermal potential and anti-arthritic efficacy of ursolic acid from niosomal gel systems. Int. Immunopharmacol. 2015, 29, 361-369. [CrossRef]

242. Morakul, B.; Teeranachaideekul, V.; Junyaprasert, V.B. Niosomal delivery of pumpkin seed oil: Development, characterisation, and physical stability. J. Microencapsul. 2019, 36, 120-129. [CrossRef]

243. Auda, S.H.; Fathalla, D.; Fetih, G.; El-Badry, M.; Shakeel, F. Niosomes as transdermal drug delivery system for celecoxib: In vitro and in vivo studies. Polym. Bull. 2016, 73, 1229-1245. [CrossRef]

244. Das, B.; Sen, S.O.; Maji, R.; Nayak, A.K.; Sen, K.K. Transferosomal gel for transdermal delivery of risperidone: Formulation optimization and ex vivo permeation. J. Drug Deliv. Sci. Technol. 2017, 38, 59-71. [CrossRef]

245. Habib, B.A.; Sayed, S.; Elsayed, G.M. Enhanced transdermal delivery of ondansetron using nanovesicular systems: Fabrication, characterization, optimization and ex-vivo permeation study-Box-Cox transformation practical example. Eur. J. Pharm. Sci. 2018, 115, 352-361. [CrossRef] [PubMed]

246. Surini, S.; Leonyza, A.; Suh, C.W. Formulation and in vitro penetration study of recombinant human epidermal growth factorloaded transfersomal emulgel. Adv. Pharm. Bull. 2020, 10, 586. [CrossRef]

247. Boge, L.; Hallstensson, K.; Ringstad, L.; Johansson, J.; Andersson, T.; Davoudi, M.; Larsson, P.T.; Mahlapuu, M.; Håkansson, J.; Andersson, M. Cubosomes for topical delivery of the antimicrobial peptide LL-37. Eur. J. Pharm. Biopharm. 2019, 134, 60-67. [CrossRef] [PubMed]

248. Khalifa, M.K. Miconazole nitrate based cubosome hydrogels for topical application. Int. J. Drug Deliv. 2015, 7, 1-12.

249. Thakkar, V.; Korat, V.; Baldaniya, L.; Gohel, M.; Gandhi, T.; Patel, N. Development and characterization of novel hydrogel containing antimicrobial drug for treatment of burns. Int. J. Pharm. Investig. 2016, 6, 158-168.

250. Khan, S.; Jain, P.; Jain, S.; Jain, R.; Bhargava, S.; Jain, A. Topical Delivery of Erythromycin through Cubosomes for Acne. Pharm. Nanotechnol. 2018, 6, 38-47. [CrossRef]

251. Sureka, S.; Gupta, G.; Agarwal, M.; Mishra, A.; Santosh, K.S.; Ravindra, P.S.; Sah, S.K.; de Jesus, A.P.T.; Dua, K. Formulation, In-Vitro and Ex-Vivo Evaluation of Tretinoin Loaded Cubosomal Gel for the Treatment of Acne. Recent. Pat. Drug Deliv. Formul. 2018, 12, 121-129. [CrossRef]

252. Sharma, R.; Kaur, G.; Kapoor, D. Fluconazole Loaded Cubosomal Vesicles for Topical Delivery. Int. J. Drug Dev. Res. 2015, 7, 32-41.

253. Gazga-Urioste, C.; Rivera-Becerril, E.; Pérez-Hernández, G.; Angélica Noguez-Méndez, N.; Faustino-Vega, A.; Tomás Quirino-Barreda, C. Physicochemical characterization and thermal behavior of hexosomes containing ketoconazole as potential topical antifungal delivery system. Drug Dev. Ind. Pharm. 2019, 45, 168-176. [CrossRef]

254. Rapalli, V.K.; Banerjee, S.; Khan, S.; Jha, P.N.; Gupta, G.; Dua, K.; Hasnain, M.S.; Nayak, A.K.; Dubey, S.K.; Singhvi, G. QbD-driven formulation development and evaluation of topical hydrogel containing ketoconazole loaded cubosomes. Mater. Sci. Eng. C 2021, 119, 111548. [CrossRef] [PubMed]

255. Kumar, P.; Singh, S.K.; Handa, V.; Kathuria, H. Oleic Acid Nanovesicles of Minoxidil for Enhanced Follicular Delivery. Medicines 2018, 5, 103. [CrossRef]

256. Esposito, E.; Drechsler, M.; Mariani, P.; Panico, A.M.; Cardile, V.; Crascì, L.; Carducci, F.; Graziano, A.C.E.; Cortesi, R.; Puglia, C. Nanostructured lipid dispersions for topical administration of crocin, a potent antioxidant from saffron (Crocus sativus L.). Mater. Sci. Eng. C 2017, 71, 669-677. [CrossRef] [PubMed]

257. Nithya, R.; Jerold, P.; Siram, K. Cubosomes of dapsone enhanced permeation across the skin. J. Drug Deliv. Sci. Technol. 2018, 48, 75-81. [CrossRef]

258. Salah, S.; Mahmoud, A.A.; Kamel, A.O. Etodolac transdermal cubosomes for the treatment of rheumatoid arthritis: Ex vivo permeation and in vivo pharmacokinetic studies. Drug Deliv. 2017, 24, 846-856. [CrossRef] [PubMed]

259. Peng, X.; Zhou, Y.; Han, K.; Qin, L.; Dian, L.; Li, G.; Pan, X.; Wu, C. Characterization of cubosomes as a targeted and sustained transdermal delivery system for capsaicin. Drug Des. Dev. Ther. 2015, 9, 4209. [CrossRef]

260. Zhai, J.; Tan, F.H.; Luwor, R.B.; Srinivasa Reddy, T.; Ahmed, N.; Drummond, C.J.; Tran, N. In Vitro and In Vivo Toxicity and Biodistribution of Paclitaxel-Loaded Cubosomes as a Drug Delivery Nanocarrier: A Case Study Using an A431 Skin Cancer Xenograft Model. ACS Appl. Bio. Mater. 2020, 3, 4198-4207. [CrossRef] 
261. Janakiraman, K.; Krishnaswami, V.; Sethuraman, V.; Rajendran, V.; Kandasamy, R. Development of methotrexate-loaded cubosomes with improved skin permeation for the topical treatment of rheumatoid arthritis. Appl. Nanosci. 2019, 9, 1781. [CrossRef]

262. Li, J.C.; Zhu, N.; Zhu, J.X.; Zhang, W.J.; Zhang, H.M.; Wang, Q.Q.; Wu, X.X.; Wang, X.; Zhang, J.; Hao, J.F. Self-Assembled Cubic Liquid Crystalline Nanoparticles for Transdermal Delivery of Paeonol. Med. Sci. Monit. 2015, 21, 3298-3310. [CrossRef]

263. Badran, M.; Ahmad, A.; Raish, M.; Kazi, M. Development, characterization and in vitro skin permeation studies of lornoxicamloaded cubosomes (Novel nanocarriers) versus liposomes. Lat. Am. J. Pharm. 2016, 35, 358-365.

264. Badie, H.; Abbas, H. Novel small self-assembled resveratrol-bearing cubosomes and hexosomes: Preparation, charachterization, and ex vivo permeation. Drug Dev. Ind. Pharm. 2018, 44, 2013-2025. [CrossRef] [PubMed]

265. Kurangi, B.; Jalalpure, S.; Jagwani, S. Formulation and evaluation of resveratrol loaded cubosomal nanoformulation for topical delivery. Curr. Drug Deliv. 2020. [CrossRef] [PubMed]

266. Elgindy, N.A.; Mehanna, M.M.; Mohyeldin, S.M. Self-assembled nano-architecture liquid crystalline particles as a promising carrier for progesterone transdermal delivery. Int. J. Pharm. 2016, 501, 167-179. [CrossRef]

267. Kuriachan, M.A. Fabrication \& Evaluation of Ketoprofen Loaded Cubogel for Topical Sustained Delivery. Int. J. Res. Rev. 2018, 5, 2349-9788.

268. Archana, A.; Sri, K.V.; Madhuri, M.; Kumar, A.; Reddy, M. Curcumin Loaded Nano Cubosomal Hydrogel: Preparation, In Vitro Characterization and Antibacterial Activity. Chem. Sci. Trans. 2015, 4, 75-80.

269. El-Komy, M.; Shalaby, S.; Hegazy, R.; Abdel Hay, R.; Sherif, S.; Bendas, E. Assessment of cubosomal alpha lipoic acid gel efficacy for the aging face: A single-blinded, placebo-controlled, right-left comparative clinical study. J. Cosmet. Dermatol. 2017, 16, 358-363. [CrossRef]

270. Baroli, B. Penetration of nanoparticles and nanomaterials in the skin: Fiction or reality? J. Pharm. Sci. 2009, 99, 21-50. [CrossRef]

271. Basavaraj, K.H. Nanotechnology in medicine and relevance to dermatology: Present concepts. Indian J. Dermatol. 2012, 57, 169-174. [CrossRef]

272. Schulman, J.H.; Stoeckenius, W.; Price, L.M. Mechanism of formation and structure of micro emulsions by electron microscopy. J. Phys. Chem. 1959, 63, 1677. [CrossRef]

273. Tadros, T.; Izquierdo, P.; Esquena, J.; Solans, C. Formation and stability of nano-emulsions. Adv. Colloid Interface Sci. 2004, 108-109, 303-318. [CrossRef]

274. Lee, V.H.L. Nanotechnology: Challenging the limit of creativity in targeted drug delivery. Adv. Drug Deliv. Rev. 2004, 56, 1527-1528. [CrossRef]

275. Hoar, T.P.; Schulman, J.H. Transparent water-in-oil dispersions: The oleopathic hydro-micelle. Nature 1943, 152, 102. [CrossRef]

276. Heuschkel, S.; Goebel, A.; Neubert, R.H.H. Microemulsions-modern colloidal carrier for dermal and transdermal drug delivery. J. Pharm. Sci. 2007, 97, 603-631. [CrossRef]

277. Kreilgaard, M. Influence of microemulsions on cutaneous drug delivery. Adv. Drug Deliv. Rev. 2002, 54 (Suppl. 1). [CrossRef]

278. Lawrence, M.J.; Warisnoicharoen, W. Recent Advances in Microemulsions as Drug Delivery Vehicles; Imperial College Press: London, UK, 2006; p. 125.

279. Kogan, A.; Aserin, A.; Garti, N. Improved solubilization of carbamazepine and structural transitions in nonionic microemulsions upon aqueous phase dilution. J. Colloid Interface Sci. 2007, 315, 637-647. [CrossRef] [PubMed]

280. Kogan, A.; Garti, N. Microemulsions as transdermal drug delivery vehicles. Adv. Colloid Interface Sci. 2006, 123-126, 369-385. [CrossRef] [PubMed]

281. Anton, N.; Benoit, J.-P.; Saulnier, P. Design and production of nanoparticles formulated from nanoemulsion templates-A review. J. Control. Release 2008, 128, 185-199. [CrossRef] [PubMed]

282. McClements, D.J. Nanoemulsions versus microemulsions: Terminology, differences, and similarities. Soft Matter. 2012, 8, 1719-1729. [CrossRef]

283. Badnjevic, A. CMBEBIH 2017: Proceedings of the International Conference on Medical and Biological Engineering 2017; Springer Singapore: New York, NY, USA, 2017; p. 825.

284. Alvarado, H.L.; Abrego, G.; Souto, E.B.; Garduno-Ramirez, M.L.; Clares, B.; Garcia, M.L.; Calpena, A.C. Nanoemulsions for dermal controlled release of oleanolic and ursolic acids: In vitro, ex vivo and in vivo characterization. Colloids Surf. B Biointerfaces 2015, 130, 40-47. [CrossRef]

285. Goindi, S.; Kaur, R.; Kaur, R. An ionic liquid-in-water microemulsion as a potential carrier for topical delivery of poorly water soluble drug: Development, ex-vivo and in-vivo evaluation. Int. J. Pharm. 2015, 495, 913-923. [CrossRef]

286. Negi, P.; Singh, B.; Sharma, G.; Beg, S.; Katare, O.P. Biocompatible lidocaine and prilocaine loaded-nanoemulsion system for enhanced percutaneous absorption: QbD-based optimisation, dermatokinetics and in vivo evaluation. J. Microencapsul. 2015, 32, 419-431. [CrossRef]

287. Coneac, G.; Vlaia, V.; Olariu, I.; Mut, A.M.; Anghel, D.F.; Ilie, C.; Popoiu, C.; Lupuleasa, D.; Vlaia, L. Development and Evaluation of New Microemulsion-Based Hydrogel Formulations for Topical Delivery of Fluconazole. AAPS PharmSciTech 2015, 16, 889-904. [CrossRef]

288. Lv, X.; Liu, T.; Ma, H.; Tian, Y.; Li, L.; Li, Z.; Gao, M.; Zhang, J.; Tang, Z. Preparation of Essential Oil-Based Microemulsions for Improving the Solubility, pH Stability, Photostability, and Skin Permeation of Quercetin. AAPS PharmSciTech 2017, 18, 3097-3104. [CrossRef] 
289. Kaur, A.; Katiyar, S.S.; Kushwah, V.; Jain, S. Nanoemulsion loaded gel for topical co-delivery of clobitasol propionate and calcipotriol in psoriasis. Nanomedicine 2017, 13, 1473-1482. [CrossRef] [PubMed]

290. Rajitha, P.; Shammika, P.; Aiswarya, S.; Gopikrishnan, A.; Jayakumar, R.; Sabitha, M. Chaulmoogra oil based methotrexate loaded topical nanoemulsion for the treatment of psoriasis. J. Drug Deliv. Sci. Technol. 2019, 49, 463-476. [CrossRef]

291. Pham, J.; Nayel, A.; Hoang, C.; Elbayoumi, T. Enhanced effectiveness of tocotrienol-based nano-emulsified system for topical delivery against skin carcinomas. Drug Deliv. 2016, 23, 1514-1524. [CrossRef] [PubMed]

292. Wang, C.; Zhu, J.; Zhang, D.; Yang, Y.; Zheng, L.; Qu, Y.; Yang, X.; Cui, X. Ionic liquid-Microemulsions assisting in the transdermal delivery of Dencichine: Preparation, in-vitro and in-vivo evaluations, and investigation of the permeation mechanism. Int. J. Pharm. 2018, 535, 120-131. [CrossRef] [PubMed]

293. El-Leithy, E.S.; Ibrahim, H.K.; Sorour, R.M. In vitro and in vivo evaluation of indomethacin nanoemulsion as a transdermal delivery system. Drug Deliv. 2015, 22, 1010-1017. [CrossRef] [PubMed]

294. Harwansh, R.K.; Mukherjee, P.K.; Bahadur, S.; Biswas, R. Enhanced permeability of ferulic acid loaded nanoemulsion based gel through skin against UVA mediated oxidative stress. Life Sci. 2015, 141, 202-211. [CrossRef] [PubMed]

295. Naz, Z.; Ahmad, F.J. Curcumin-loaded colloidal carrier system: Formulation optimization, mechanistic insight, ex vivo and in vivo evaluation. Int. J. Nanomed. 2015, 10, 4293-4307. [CrossRef]

296. Kumar, N. D-optimal experimental approach for designing topical microemulsion of itraconazole: Characterization and evaluation of antifungal efficacy against a standardized Tinea pedis infection model in Wistar rats. Eur. J. Pharm. Sci. 2015, 67, 97-112. [CrossRef]

297. Wan, T.; Xu, T.; Pan, J.; Qin, M.; Pan, W.; Zhang, G.; Wu, Z.; Wu, C.; Xu, Y. Microemulsion based gel for topical dermal delivery of pseudolaric acid B: In vitro and in vivo evaluation. Int. J. Pharm. 2015, 493, 111-120. [CrossRef]

298. Chhibber, T.; Wadhwa, S.; Chadha, P.; Sharma, G.; Katare, O.P. Phospholipid structured microemulsion as effective carrier system with potential in methicillin sensitive Staphylococcus aureus (MSSA) involved burn wound infection. J. Drug. Target. 2015, 23, 943-952. [CrossRef] [PubMed]

299. Ujhelyi, Z.; Kalantari, A.; Vecsernyes, M.; Roka, E.; Fenyvesi, F.; Poka, R.; Kozma, B.; Bacskay, I. The enhanced inhibitory effect of different antitumor agents in self-microemulsifying drug delivery systems on human cervical cancer HeLa cells. Molecules 2015, 20, 13226-13239. [CrossRef]

300. Cojocaru, V.; Ranetti, A.E.; Hinescu, L.G.; Ionescu, M.; Cosmescu, C.; Postoarca, A.G.; Cinteza, L.O. Formulation and evaluation of in vitro release kinetics of NA3CADTPA decorporation agent embedded in microemulsion-based gel formulation for topical delivery. Farmacia 2015, 63, 656-664.

301. Yutani, R.; Teraoka, R.; Kitagawa, S. Microemulsion using polyoxyethylene sorbitan trioleate and its usage for skin delivery of resveratrol to protect skin against UV-induced damage. Chem. Pharm. Bull. 2015, 63, 741-745. [CrossRef] [PubMed]

302. Hussain, A.; Samad, A.; Singh, S.K.; Ahsan, M.N.; Haque, M.W.; Faruk, A.; Ahmed, F.J. Nanoemulsion gel-based topical delivery of an antifungal drug: In vitro activity and in vivo evaluation. Drug Deliv. 2016, 23, 642-657. [CrossRef] [PubMed]

303. Sharma, G.; Dhankar, G.; Thakur, K.; Raza, K.; Katare, O.P. Benzyl Benzoate-Loaded Microemulsion for Topical Applications: Enhanced Dermatokinetic Profile and Better Delivery Promises. AAPS PharmSciTech 2016, 17, 1221-1231. [CrossRef] [PubMed]

304. Mahtab, A.; Anwar, M.; Mallick, N.; Naz, Z.; Jain, G.K.; Ahmad, F.J. Transungual Delivery of Ketoconazole Nanoemulgel for the Effective Management of Onychomycosis. AAPS PharmSciTech 2016, 17, 1477-1490. [CrossRef]

305. Shen, C.-y.; Xu, P.-h.; Shen, B.-d.; Min, H.-y.; Li, X.-r.; Han, J.; Yuan, H.-l. Nanogel for dermal application of the triterpenoids isolated from Ganoderma lucidum (GLT) for frostbite treatment. Drug Deliv. 2016, 23, 610-618. [CrossRef]

306. Miastkowska, M.; Sikora, E.; Ogonowski, J.; Zielina, M.; Ludzik, A. The kinetic study of isotretinoin release from nanoemulsion. Colloids Surf. A Physicochem. Eng. Asp. 2016, 510, 63-68. [CrossRef]

307. Nasr, M.; Abdel-Hamid, S. Optimizing the dermal accumulation of a tazarotene microemulsion using skin deposition modeling. Drug Dev. Ind. Pharm. 2016, 42, 636-643. [CrossRef]

308. Cavalcanti, A.L.M.; Reis, M.Y.F.A.; Silva, G.C.L.; Ramalho, I.M.M.; Guimaraes, G.P.; Silva, J.A.; Saraiva, K.L.A.; Damasceno, B.P.G.L. Microemulsion for topical application of pentoxifylline: In vitro release and in vivo evaluation. Int. J. Pharm. 2016, 506, 351-360. [CrossRef] [PubMed]

309. Amarji, B.; Garg, N.K.; Singh, B.; Katare, O.P. Microemulsions mediated effective delivery of methotrexate hydrogel: More than a tour de force in psoriasis therapeutics. J. Drug Target. 2016, 24, 147-160. [CrossRef] [PubMed]

310. Djekic, L.; Martinovic, M.; Stepanovic-Petrovic, R.; Micov, A.; Tomic, M.; Primorac, M. Formulation of hydrogel-thickened nonionic microemulsions with enhanced percutaneous delivery of ibuprofen assessed in vivo in rats. Eur. J. Pharm. Sci. 2016, 92, 255-265. [CrossRef]

311. Sahoo, S.; Pani, N.R.; Sahoo, S.K. Effect of microemulsion in topical sertaconazole hydrogel: In vitro and in vivo study. Drug Deliv. 2016, 23, 338-345. [CrossRef] [PubMed]

312. Telo, I.; Pescina, S.; Padula, C.; Santi, P.; Nicoli, S. Mechanisms of imiquimod skin penetration. Int. J. Pharm. 2016, 511, 516-523. [CrossRef]

313. Musa, S.H.; Basri, M.; Masoumi, H.R.F.; Shamsudin, N.; Salim, N. Enhancement of physicochemical properties of nanocolloidal carrier loaded with cyclosporine for topical treatment of psoriasis: In vitro diffusion and in vivo hydrating action. Int. J. Nanomed. 2017, 12, 2427-2441. [CrossRef] 
314. Barradas, T.N.; Senna, J.P.; Cardoso, S.A.; Nicoli, S.; Padula, C.; Santi, P.; Rossi, F.; de Holanda e Silva, K.G.; Mansur, C.R.E. Hydrogel-thickened nanoemulsions based on essential oils for topical delivery of psoralen: Permeation and stability studies. Eur. J. Pharm. Sci. 2017, 116, 38-50. [CrossRef]

315. Teo, S.Y.; Yew, M.Y.; Lee, S.Y.; Rathbone, M.J.; Gan, S.N.; Coombes, A.G.A. In Vitro Evaluation of Novel Phenytoin-Loaded Alkyd Nanoemulsions Designed for Application in Topical Wound Healing. J. Pharm. Sci. 2017, 106, 377-384. [CrossRef] [PubMed]

316. Betzler de Oliveira de Siqueira, L.; da Silva Cardoso, V.; Rodrigues, I.A.; Vazquez-Villa, A.L.; Pereira dos Santos, E.; da Costa Leal Ribeiro Guimaraes, B.; dos Santos Cerqueira Coutinho, C.; Vermelho, A.B.; Ricci, E., Jr. Development and evaluation of zinc phthalocyanine nanoemulsions for use in photodynamic therapy for Leishmania spp. Nanotechnology 2017, 28, 65101. [CrossRef] [PubMed]

317. Wan, T.; Pan, J.; Long, Y.; Yu, K.; Wang, Y.; Pan, W.; Ruan, W.; Qin, M.; Wu, C.; Xu, Y. Dual roles of TPGS based microemulsion for tacrolimus: Enhancing the percutaneous delivery and anti-psoriatic efficacy. Int. J. Pharm. 2017, 528, 511-523. [CrossRef] [PubMed]

318. Nasr, M.; Abdel-Hamid, S.; Moftah, N.H.; Fadel, M.; Alyoussef, A.A. Jojoba Oil Soft Colloidal Nanocarrier of a Synthetic Retinoid: Preparation, Characterization and Clinical Efficacy in Psoriatic Patients. Curr. Drug Deliv. 2017, 14, 426-432. [CrossRef]

319. Kumari, B.; Kesavan, K. Effect of chitosan coating on microemulsion for effective dermal clotrimazole delivery. Pharm. Dev. Technol. 2017, 22, 617-626. [CrossRef]

320. Moghimipour, E.; Salimi, A.; Changizi, S. Preparation and microstructural characterization of Griseofulvin microemulsions using different experimental methods: SAXS and DSC. Adv. Pharm. Bull. 2017, 7, 281-289. [CrossRef]

321. Kaci, M.; Belhaffef, A.; Meziane, S.; Dostert, G.; Menu, P.; Velot, E.; Desobry, S.; Arab-Tehrany, E. Nanoemulsions and topical creams for the safe and effective delivery of lipophilic antioxidant coenzyme Q10. Colloids Surf. B Biointerfaces 2018, 167, 165-175. [CrossRef]

322. Barradas, T.N.; Senna, J.P.; Cardoso, S.A.; de Holanda e Silva, K.G.; Elias Mansur, C.R. Formulation characterization and in vitro drug release of hydrogel-thickened nanoemulsions for topical delivery of 8-methoxypsoralen. Mater Sci. Eng. C 2018, 92, 245-253. [CrossRef]

323. Najafi-Taher, R.; Ghaemi, B.; Amani, A. Delivery of adapalene using a novel topical gel based on tea tree oil nano-emulsion: Permeation, antibacterial and safety assessments. Eur. J. Pharm. Sci. 2018, 120, 142-151. [CrossRef]

324. Fachel, F.N.S.; Nemitz, M.C.; Medeiros-Neves, B.; Veras, K.S.; Bassani, V.L.; Koester, L.S.; Henriques, A.T.; Teixeira, H.F. A novel, simplified and stability-indicating high-throughput ultra-fast liquid chromatography method for the determination of rosmarinic acid in nanoemulsions, porcine skin and nasal mucosa. J. Chromatogr. BAnal. Technol. Biomed. Life Sci. 2018, 1083, 233-241. [CrossRef] [PubMed]

325. Argenta, D.F.; Bidone, J.; Koester, L.S.; Bassani, V.L.; Simoes, C.M.O.; Teixeira, H.F. Topical Delivery of Coumestrol from Lipid Nanoemulsions Thickened with Hydroxyethylcellulose for Antiherpes Treatment. AAPS PharmSciTech 2018, 19, 192-200. [CrossRef]

326. Bakshi, P.; Jiang, Y.; Nakata, T.; Akaki, J.; Matsuoka, N.; Banga, A.K. Formulation development and characterization of nanoemulsion-based formulation for topical delivery of heparinoid. J. Pharm. Sci. Technol. 2018, 107, 2883-2890. [CrossRef] [PubMed]

327. Hajjar, B.; Zier, K.-I.; Khalid, N.; Azarmi, S.; Lobenberg, R. Evaluation of a microemulsion-based gel formulation for topical drug delivery of diclofenac sodium. J. Pharm. Investig. 2018, 48, 351-362. [CrossRef]

328. Kim, K.-T.; Kim, M.-H.; Park, J.-H.; Lee, J.-Y.; Cho, H.-J.; Yoon, I.-S.; Kim, D.-D. Microemulsion-based hydrogels for enhancing epidermal/dermal deposition of topically administered 20(S)-protopanaxadiol: In vitro and in vivo evaluation studies. J. Ginseng Res. 2018, 42, 512-523. [CrossRef] [PubMed]

329. Neubert, R.H.H.; Sommer, E.; Schoelzel, M.; Tuchscherer, B.; Mrestani, Y.; Wohlrab, J. Dermal peptide delivery using enhancer moleculs and colloidal carrier systems. Part II: Tetrapeptide PKEK. Eur. J. Pharm. Biopharm. 2018, 124, 28-33. [CrossRef] [PubMed]

330. Yu, J.; Xiao, Z.; Zhao, R.; Lu, C.; Zhang, Y. Astilbin emulsion improves guinea pig lesions in a psoriasis-like model by suppressing IL-6 and IL-22 via p38 MAPK. Mol. Med. Rep. 2018, 17, 3789-3796. [CrossRef] [PubMed]

331. Ghiasi, Z.; Esmaeli, F.; Aghajani, M.; Ghazi-Khansari, M.; Faramarzi, M.A.; Amani, A. Enhancing analgesic and anti-inflammatory effects of capsaicin when loaded into olive oil nanoemulsion: An in vivo study. Int. J. Pharm. 2019, 559, 341-347. [CrossRef]

332. Ahmad, J.; Gautam, A.; Komath, S.; Bano, M.; Garg, A.; Jain, K. Topical Nano-emulgel for Skin Disorders: Formulation Approach and Characterization. Recent Pat. Anti-Infect. Drug Discov. 2019, 14, 36-48. [CrossRef]

333. Nemitz, M.C.; von Poser, G.L.; Teixeira, H.F. In vitro skin permeation/retention of daidzein, genistein and glycitein from a soybean isoflavone rich fraction-loaded nanoemulsions and derived hydrogels. J. Drug. Deliv. Sci. Technol. 2019, 51, 63-69. [CrossRef]

334. Pleguezuelos-Villa, M.; Nacher, A.; Hernandez, M.J.; Ofelia Vila Buso, M.A.; Ruiz Sauri, A.; Diez-Sales, O. Mangiferin nanoemulsions in treatment of inflammatory disorders and skin regeneration. Int. J. Pharm. 2019, 564, 299-307. [CrossRef]

335. de Oliveira de Siqueira, L.B.; dos Santos Matos, A.P.; da Silva Cardoso, V.; Villanova, J.C.O.; da Costa Leal Ribeiro Guimaraes, B.; dos Santos, E.P.; Vermelho, A.B.; Santos-Oliveira, R.; Ricci, E., Jr. Clove oil nanoemulsion showed potent inhibitory effect against Candida spp. Nanotechnology 2019, 30, 425101. [CrossRef]

336. Dhawan, S.; Nanda, S. In Vitro Estimation of Photo-Protective Potential of Pomegranate Seed Oil and Development of a Nanoformulation. Curr. Nutr. Food Sci. 2019, 15, 87-102. [CrossRef] 
337. Hu, X.-B.; Kang, R.-R.; Tang, T.-T.; Li, Y.-J.; Wu, J.-Y.; Wang, J.-M.; Liu, X.-Y.; Xiang, D.-X. Topical delivery of 3,5,4'-trimethoxytrans-stilbene-loaded microemulsion-based hydrogel for the treatment of osteoarthritis in a rabbit model. Drug Deliv. Transl. Res. 2019, 9, 357-365. [CrossRef]

338. Tung, N.-T.; Vu, V.-D.; Nguyen, P.-L. DoE-based development, physicochemical characterization, and pharmacological evaluation of a topical hydrogel containing betamethasone dipropionate microemulsion. Colloids Surf. B Biointerfaces 2019, 181, 480-488. [CrossRef]

339. Chhibber, S.; Gondil, V.S.; Singla, L.; Kumar, M.; Chhibber, T.; Sharma, G.; Sharma, R.K.; Wangoo, N.; Katare, O.P. Effective Topical Delivery of H-AgNPs for Eradication of Klebsiella pneumoniae-Induced Burn Wound Infection. AAPS PharmSciTech 2019, 20, 1-13. [CrossRef] [PubMed]

340. Ravikumar, P.; Tatke, P. Design of an encapsulated topical formulation for chemoprevention of skin cancer. Int. J. Pharm. Sci. Res. 2019, 10, 309-319.

341. Ahmad, N.; Ahmad, R.; Mohammed Buheazaha, T.; Salman AlHomoud, H.; Al-Nasif, H.A.; Sarafroz, M. A comparative ex vivo permeation evaluation of a novel 5-Fluorocuracil nanoemulsion-gel by topically applied in the different excised rat, goat, and cow skin. Saudi. J. Biol. Sci. 2020, 27, 1024-1040. [CrossRef] [PubMed]

342. Fasolo, D.; Pippi, B.; Meirelles, G.; Zorzi, G.; Fuentefria, A.M.; von Poser, G.; Teixeira, H.F. Topical delivery of antifungal Brazilian red propolis benzophenones-rich extract by means of cationic lipid nanoemulsions optimized by means of Box-Behnken Design. J. Drug Deliv. Sci. Technol. 2020, 56, 101573. [CrossRef]

343. Algahtani, M.S.; Ahmad, M.Z.; Ahmad, J. Nanoemulgel for improved topical delivery of retinyl palmitate: Formulation design and stability evaluation. Nanomaterials 2020, 10, 848. [CrossRef] [PubMed]

344. Espinoza, L.C.; Vera-Garcia, R.; Silva-Abreu, M.; Domenech, O.; Badia, J.; Rodriguez-Lagunas, M.J.; Clares, B.; Calpena, A.C. Topical pioglitazone nanoformulation for the treatment of atopic dermatitis: Design, characterization and efficacy in hairless mouse model. Pharmaceutics 2020, 12, 255. [CrossRef]

345. Pandey, S.S.; Maulvi, F.A.; Patel, P.S.; Shukla, M.R.; Shah, K.M.; Gupta, A.R.; Joshi, S.V.; Shah, D.O. Cyclosporine laden tailored microemulsion-gel depot for effective treatment of psoriasis: In vitro and in vivo studies. Colloids Surf. B Biointerfaces 2020, 186, 110681. [CrossRef] [PubMed]

346. Das, S.; Lee, S.H.; Chia, V.D.; Chow, P.S.; MacBeath, C.; Liu, Y.; Shlieout, G. Development of microemulsion based topical ivermectin formulations: Pre-formulation and formulation studies. Colloids Surf. B: Biointerfaces 2020, 189, 110823. [CrossRef]

347. Praca, F.G.; Viegas, J.S.R.; Peh, H.Y.; Garbin, T.N.; Medina, W.S.G.; Bentley, M.V.L.B. Microemulsion co-delivering vitamin A and vitamin $\mathrm{E}$ as a new platform for topical treatment of acute skin inflammation. Mater. Sci. Eng. C 2020, 110, 110639. [CrossRef]

348. Abu-Azzam, O.; Nasr, M. In vitro anti-inflammatory potential of phloretin microemulsion as a new formulation for prospective treatment of vaginitis. Pharm. Dev. Technol. 2020, 25, 930-935. [CrossRef]

349. Garcia-Bilbao, A.; Gomez-Fernandez, P.; Larush, L.; Soroka, Y.; Suarez-Merino, B.; Frusic-Zlotkin, M.; Magdassi, S.; Goni-de-Cerio, F. Preparation, characterization, and biological evaluation of retinyl palmitate and Dead Sea water loaded nanoemulsions toward topical treatment of skin diseases. J. Bioact. Compat. Polym. 2020, 35, 24-38. [CrossRef]

350. Yang, M.; Gu, Y.; Yang, D.; Tang, X.; Liu, J. Development of triptolide-nanoemulsion gels for percutaneous administration: Physicochemical, transport, pharmacokinetic and pharmacodynamic characteristics. J. Nano Biotechnol. 2017, 15, 88. [CrossRef] [PubMed]

351. Jagdale, S.; Chaudhari, B. Optimization of microemulsion based transdermal gel of triamcinolone. Recent Pat. Anti-Infect. Drug Discov. 2017, 12, 61-78. [CrossRef] [PubMed]

352. Mehta, T. Formulation, characterization, and ex vivo evaluation of microemulsion based gel of nicotinamide. Asian J. Pharm. 2018, 12 (Suppl. 1), S115-S121.

353. Sabouri, M.; Samadi, A.; Nasrollahi, S.A.; Farboud, E.S.; Mirrahimi, B.; Hassanzadeh, H.; Kashani, M.N.; Dinarvand, R.; Firooz, A. Tretinoin Loaded Nanoemulsion for Acne Vulgaris: Fabrication, Physicochemical and Clinical Efficacy Assessments. Ski. Pharmacol. Physiol. 2018, 31, 316-323. [CrossRef] [PubMed]

354. Khiljee, S.; Ur Rehman, N.; Khiljee, T.; Loebenberg, R.; Ahmad, R.S. Formulation and clinical evaluation of topical dosage forms of Indian Penny Wort, walnut and turmeric in eczema. Pak. J. Pharm. Sci. 2015, 28, 2001-2007.

355. Rachmawati, H.; Budiputra, D.K.; Mauludin, R. Curcumin nanoemulsion for transdermal application: Formulation and evaluation. Drug Dev. Ind. Pharm. 2015, 41, 560-566. [CrossRef] [PubMed]

356. Mostafa, D.M.; Abd El-Alim, S.H.; Asfour, M.H.; Al-Okbi, S.Y.; Mohamed, D.A.; Awad, G. Transdermal nanoemulsions of Foeniculum vulgare Mill. essential oil: Preparation, characterization and evaluation of antidiabetic potential. J. Drug Deliv. Sci. Technol. 2015, 29, 99-106. [CrossRef]

357. Yehia, R.; Hathout, R.M.; Attia, D.A.; Elmazar, M.M.; Mortada, N.D. Anti-tumor efficacy of an integrated methyl dihydrojasmonate transdermal microemulsion system targeting breast cancer cells: In vitro and in vivo studies. Colloids Surf. B Biointerfaces 2017, 155, 512-521. [CrossRef] [PubMed]

358. Omar, A.M.; Ammar, N.M.; Hussein, R.A.; Mostafa, D.M.; Basha, M.; Abdel Hamid, M.F. Boswellia carterii Birdwood topical microemulsion for the treatment of inflammatory dermatological conditions; a prospective study. Trop. J. Nat. Prod. Res. 2020, 4, 372-377.

359. Soppimath, K.S.; Aminabhavi, T.M.; Kulkarni, A.R.; Rudzinski, W.E. Biodegradable polymeric nanoparticles as drug delivery devices. J. Control. Release 2001, 70, 1-20. [CrossRef] 
360. Cano, A.; Ettcheto, M.; Chang, J.-H.; Barroso, E.; Espina, M.; Kühne, B.A.; Barenys, M.; Auladell, C.; Folch, J.; Souto, E.B.; et al. Dual-drug loaded nanoparticles of Epigallocatechin-3-gallate (EGCG)/ Ascorbic acid enhance therapeutic efficacy of EGCG in a APPswe/PS1dE9 Alzheimer's disease mice model. J. Control. Release 2019, 301, 62-75. [CrossRef]

361. Alvarez-Román, R.; Barre, G.; Guy, R.H.; Fessi, H. Biodegradable polymer nanocapsules containing a sunscreen agent: Preparation and photoprotection. Eur. J. Pharm. Biopharm. 2001, 52, 191-195. [CrossRef]

362. Lboutounne, H.; Chaulet, J.-F.; Ploton, C.; Falson, F.; Pirot, F. Sustained ex vivo skin antiseptic activity of chlorhexidine in poly ( $\epsilon$-caprolactone) nanocapsule encapsulated form and as a digluconate. J. Control. Release 2002, 82, 319-334. [CrossRef]

363. Milao, D.; Knorst, M.; Richter, W.; Guterres, S. Hydrophilic gel containing nanocapsules of diclofenac: Development, stability study and physico-chemical characterization. Pharm. Int. J. Pharm. Sci. 2003, 58, 325-329.

364. Kim, D.-G.; Jeong, Y.-I.; Choi, C.; Roh, S.-H.; Kang, S.-K.; Jang, M.-K.; Nah, J.-W. Retinol-encapsulated low molecular water-soluble chitosan nanoparticles. Int. J. Pharm. 2006, 319, 130-138. [CrossRef]

365. Shim, J.; Kang, H.S.; Park, W.-S.; Han, S.-H.; Kim, J.; Chang, I.-S. Transdermal delivery of mixnoxidil with block copolymer nanoparticles. J. Control. Release 2004, 97, 477-484. [CrossRef]

366. Lboutounne, H.; Faivre, V.; Falson, F.; Pirot, F. Characterization of transport of chlorhexidine-loaded nanocapsules through hairless and wistar rat skin. Ski. Pharmacol. Physiol. 2004, 17, 176-182. [CrossRef] [PubMed]

367. Jiménez, M.; Pelletier, J.; Bobin, M.; Martini, M. Influence of encapsulation on the in vitro percutaneous absorption of octyl methoxycinnamate. Int. J. Pharm. 2004, 272, 45-55. [CrossRef] [PubMed]

368. Alhaique, F.; Casadei, M.A.; Cencetti, C.; Coviello, T.; Di Meo, C.; Matricardi, P.; Montanari, E.; Pacelli, S.; Paolicelli, P. From macro to nano polysaccharide hydrogels: An opportunity for the delivery of drugs. J. Drug Deliv. Sci. Technol. 2016, 32, 88-99. [CrossRef]

369. Alhaique, F.; Matricardi, P.; Di Meo, C.; Coviello, T.; Montanari, E. Polysaccharide-based self-assembling nanohydrogels: An overview on 25-years research on pullulan. J. Drug Deliv. Sci. Technol. 2015, 30, 300-309. [CrossRef]

370. Alvarez-Román, R.; Naik, A.; Kalia, Y.; Guy, R.H.; Fessi, H. Skin penetration and distribution of polymeric nanoparticles. J. Control. Release 2004, 99, 53-62. [CrossRef]

371. Deng, S.Y.; Gigliobianco, M.R.; Censi, R.; Di Martino, P. Polymeric Nanocapsules as Nanotechnological Alternative for Drug Delivery System: Current Status, Challenges and Opportunities. Nanomaterials 2020, 10, 847. [CrossRef]

372. Couvreur, P.; Barratt, G.; Fattal, E.; Vauthier, C. Nanocapsule technology: A review. Crit. Rev. Ther. Drug Carr. Syst. 2002, 19, 99-134. [CrossRef]

373. Schaffazick, S.R.; Guterres, S.S.; de Lucca Freitas, L.; Pohlmann, A.R. Caracterização e estabilidade físico-química de sistemas poliméricos nanoparticulados para administração de fármacos. Química Nova 2003, 26, 726-737. [CrossRef]

374. Guterres, S.S.; Alves, M.P.; Pohlmann, A.R. Polymeric nanoparticles, nanospheres and nanocapsules, for cutaneous applications. Drug Target Insights 2007, 2. [CrossRef]

375. Crucho, C.I.C.; Barros, M.T. Polymeric nanoparticles: A study on the preparation variables and characterization methods. Mater. Sci. Eng. C 2017, 80, 771-784. [CrossRef]

376. Owens, D.E.; Peppas, N.A. Opsonization, biodistribution, and pharmacokinetics of polymeric nanoparticles. Int. J. Pharm. 2006, 307, 93-102. [CrossRef] [PubMed]

377. Jawahar, N.; Meyyanathan, S. Polymeric nanoparticles for drug delivery and targeting: A comprehensive review. Int. J. Health Allied Sci. 2012, 1, 217-223. [CrossRef]

378. Zhang, Z.; Tsai, P.C.; Ramezanli, T.; Michniak-Kohn, B.B. Polymeric nanoparticles-based topical delivery systems for the treatment of dermatological diseases. Wiley Interdiscip. Rev. Nanomed. Nano Biotechnol. 2013, 5, 205-218. [CrossRef] [PubMed]

379. De Campos, A.M.; Sánchez, A.; Alonso, M.J. Chitosan nanoparticles: A new vehicle for the improvement of the delivery of drugs to the ocular surface. Application to cyclosporin A. Int. J. Pharm. 2001, 224, 159-168. [CrossRef]

380. Fessi, H.; Puisieux, F.; Devissaguet, J.P.; Ammoury, N.; Benita, S. Nanocapsule formation by interfacial polymer deposition following solvent displacement. Int. J. Pharm. 1989, 55, R1-R4. [CrossRef]

381. Sinha, V.; Bansal, K.; Kaushik, R.; Kumria, R.; Trehan, A. Poly- $\epsilon$-caprolactone microspheres and nanospheres: An overview. Int. J. Pharm. 2004, 278, 1-23. [CrossRef]

382. Amgoth, C.; Phan, C.; Banavoth, M.; Rompivalasa, S.; Tang, G. Polymer Properties: Functionalization and Surface Modified Nanoparticles. In Role of Novel Drug Delivery Vehicles in Nanobiomedicine; IntechOpen: London, UK, 2019.

383. Mathes, C.; Melero, A.; Conrad, P.; Vogt, T.; Rigo, L.; Selzer, D.; Prado, W.; De Rossi, C.; Garrigues, T.; Hansen, S. Nanocarriers for optimizing the balance between interfollicular permeation and follicular uptake of topically applied clobetasol to minimize adverse effects. J. Control. Release 2016, 223, 207-214. [CrossRef]

384. Labala, S.; Mandapalli, P.K.; Kurumaddali, A.; Venuganti, V.V.K. Layer-by-layer polymer coated gold nanoparticles for topical delivery of imatinib mesylate to treat melanoma. Mol. Pharm. 2015, 12, 878-888. [CrossRef]

385. Roque, L.V.; Dias, I.S.; Cruz, N.; Rebelo, A.; Roberto, A.; Rijo, P.; Reis, C.P. Design of finasteride-loaded nanoparticles for potential treatment of alopecia. Ski. Pharmacol. Physiol. 2017, 30, 197-204. [CrossRef]

386. Krausz, A.E.; Adler, B.L.; Cabral, V.; Navati, M.; Doerner, J.; Charafeddine, R.A.; Chandra, D.; Liang, H.; Gunther, L.; Clendaniel, A.; et al. Curcumin-encapsulated nanoparticles as innovative antimicrobial and wound healing agent. Nanomed. Nanotechnol. Biol. Med. 2015, 11, 195-206. [CrossRef] 
387. Zhai, X.; Zhang, C.; Zhao, G.; Stoll, S.; Ren, F.; Leng, X. Antioxidant capacities of the selenium nanoparticles stabilized by chitosan. J. Nanobiotechnol. 2017, 15, 1-12. [CrossRef]

388. Sun, L.; Liu, Z.; Wang, L.; Cun, D.; Tong, H.H.; Yan, R.; Chen, X.; Wang, R.; Zheng, Y. Enhanced topical penetration, system exposure and anti-psoriasis activity of two particle-sized, curcumin-loaded PLGA nanoparticles in hydrogel. J. Control. Release 2017, 254, 44-54. [CrossRef]

389. Huang, P.-H.; Hu, S.C.-S.; Lee, C.-W.; Yeh, A.-C.; Tseng, C.-H.; Yen, F.-L. Design of acid-responsive polymeric nanoparticles for 7, $3^{\prime}, 4^{\prime}$-trihydroxyisoflavone topical administration. Int. J. Nanomed. 2016, 11, 1615.

390. González-Delgado, J.A.; Castro, P.M.; Machado, A.; Araújo, F.; Rodrigues, F.; Korsak, B.; Ferreira, M.; Tomé, J.P.; Sarmento, B. Hydrogels containing porphyrin-loaded nanoparticles for topical photodynamic applications. Int. J. Pharm. 2016, 510, 221-231. [CrossRef] [PubMed]

391. Balzus, B.; Sahle, F.F.; Hönzke, S.; Gerecke, C.; Schumacher, F.; Hedtrich, S.; Kleuser, B.; Bodmeier, R. Formulation and ex vivo evaluation of polymeric nanoparticles for controlled delivery of corticosteroids to the skin and the corneal epithelium. Eur. J. Pharm. Biopharm. 2017, 115, 122-130. [CrossRef] [PubMed]

392. Silva, C.O.; Rijo, P.; Molpeceres, J.; Figueiredo, I.V.; Ascensão, L.; Fernandes, A.S.; Roberto, A.; Reis, C.P. Polymeric nanoparticles modified with fatty acids encapsulating betamethasone for anti-inflammatory treatment. Int. J. Pharm. 2015, 493, 271-284. [CrossRef]

393. Pandey, M.; Choudhury, H.; Gunasegaran, T.A.; Nathan, S.S.; Md, S.; Gorain, B.; Tripathy, M.; Hussain, Z. Hyaluronic acidmodified betamethasone encapsulated polymeric nanoparticles: Fabrication, characterisation, in vitro release kinetics, and dermal targeting. Drug Deliv. Transl. Res. 2019, 9, 520-533. [CrossRef]

394. Sahle, F.F.; Gerecke, C.; Kleuser, B.; Bodmeier, R. Formulation and comparative in vitro evaluation of various dexamethasoneloaded $\mathrm{pH}$-sensitive polymeric nanoparticles intended for dermal applications. Int. J. Pharm. 2017, 516, 21-31. [CrossRef] [PubMed]

395. Boisgard, A.-S.; Lamrayah, M.; Dzikowski, M.; Salmon, D.; Kirilov, P.; Primard, C.; Pirot, F.; Fromy, B.; Verrier, B. Innovative drug vehicle for local treatment of inflammatory skin diseases: Ex vivo and in vivo screening of five topical formulations containing poly (lactic acid)(PLA) nanoparticles. Eur. J. Pharm. Biopharm. 2017, 116, 51-60. [CrossRef]

396. Mohideen, M.; Quijano, E.; Song, E.; Deng, Y.; Panse, G.; Zhang, W.; Clark, M.R.; Saltzman, W.M. Degradable bioadhesive nanoparticles for prolonged intravaginal delivery and retention of elvitegravir. Biomaterials 2017, 144, 144-154. [CrossRef]

397. Quinteros, D.A.; Ferreira, L.M.; Schaffazick, S.R.; Palma, S.D.; Allemandi, D.A.; Cruz, L. Novel polymeric nanoparticles intended for ophthalmic administration of acetazolamide. J. Pharm. Sci. 2016, 105, 3183-3190. [CrossRef]

398. Grillo, R.; Dias, F.V.; Querobino, S.M.; Alberto-Silva, C.; Fraceto, L.F.; de Paula, E.; de Araujo, D.R. Influence of hybrid polymeric nanoparticle/thermosensitive hydrogels systems on formulation tracking and in vitro artificial membrane permeation: A promising system for skin drug-delivery. Colloids Surf. B Biointerfaces 2019, 174, 56-62. [CrossRef]

399. Frank, L.A.; Chaves, P.S.; D'Amore, C.M.; Contri, R.V.; Frank, A.G.; Beck, R.C.; Pohlmann, A.R.; Buffon, A.; Guterres, S.S. The use of chitosan as cationic coating or gel vehicle for polymeric nanocapsules: Increasing penetration and adhesion of imiquimod in vaginal tissue. Eur. J. Pharm. Biopharm. 2017, 114, 202-212. [CrossRef] [PubMed]

400. Bonferoni, M.C.; Riva, F.; Invernizzi, A.; Dellera, E.; Sandri, G.; Rossi, S.; Marrubini, G.; Bruni, G.; Vigani, B.; Caramella, C.; et al. Alpha tocopherol loaded chitosan oleate nanoemulsions for wound healing. Evaluation on cell lines and ex vivo human biopsies, and stabilization in spray dried Trojan microparticles. Eur. J. Pharm. Biopharm. 2018, 123, 31-41. [CrossRef] [PubMed]

401. Marchiori, M.C.L.; Rigon, C.; Camponogara, C.; Oliveira, S.M.; Cruz, L. Hydrogel containing silibinin-loaded pomegranate oil based nanocapsules exhibits anti-inflammatory effects on skin damage UVB radiation-induced in mice. J. Photochem. Photobiol. B Biol. 2017, 170, 25-32. [CrossRef] [PubMed]

402. Marto, J.; Ruivo, E.; Lucas, S.; Gonçalves, L.; Simões, S.; Gouveia, L.; Felix, R.; Moreira, R.; Ribeiro, H.; Almeida, A. Starch nanocapsules containing a novel neutrophil elastase inhibitor with improved pharmaceutical performance. Eur. J. Pharm. Biopharm. 2018, 127, 1-11. [CrossRef] [PubMed]

403. Jaromin, A.; Zarnowski, R.; Piętka-Ottlik, M.; Andes, D.R.; Gubernator, J. Topical delivery of ebselen encapsulated in biopolymeric nanocapsules: Drug repurposing enhanced antifungal activity. Nanomedicine 2018, 13, 1139-1155. [CrossRef]

404. Flores, F.C.; de Lima, J.A.; da Silva, C.R.; Benvegnú, D.; Ferreira, J.; Burger, M.E.; Beck, R.C.; Rolim, C.; Rocha, M.I.U.; da Veiga, M.L. Hydrogels containing nanocapsules and nanoemulsions of tea tree oil provide antiedematogenic effect and improved skin wound healing. J. Nanosci. Nanotechnol. 2015, 15, 800-809. [CrossRef]

405. Kalita, S.; Kandimalla, R.; Devi, B.; Kalita, B.; Kalita, K.; Deka, M.; Chandra Kataki, A.; Sharma, A.; Kotoky, J. Dual delivery of

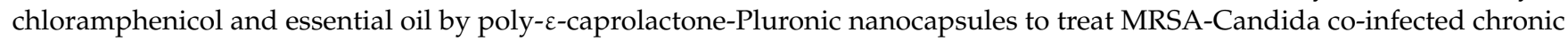
burn wounds. Rsc. Adv. 2017, 7, 1749-1758. [CrossRef]

406. Cardoso, A.M.; de Oliveira, E.G.; Coradini, K.; Bruinsmann, F.A.; Aguirre, T.; Lorenzoni, R.; Barcelos, R.C.S.; Roversi, K.; Rossato, D.R.; Pohlmann, A.R. Chitosan hydrogels containing nanoencapsulated phenytoin for cutaneous use: Skin permeation/penetration and efficacy in wound healing. Mater. Sci. Eng. C 2019, 96, 205-217. [CrossRef]

407. Jakubiak, P.; Thwala, L.N.; Cadete, A.; Préat, V.; Alonso, M.J.; Beloqui, A.; Csaba, N. Solvent-free protamine nanocapsules as carriers for mucosal delivery of therapeutics. Eur. Polym. J. 2017, 93, 695-705. [CrossRef] 
408. Beber, T.C.; de Andrade, D.F.; de Santos Chaves, P.; Pohlmann, A.R.; Guterres, S.S.; Ruver Beck, R.C. Cationic polymeric nanocapsules as a strategy to target dexamethasone to viable epidermis: Skin penetration and permeation studies. J. Nanosci. Nanotechnol. 2016, 16, 1331-1338. [CrossRef] [PubMed]

409. Silva-Flores, P.G.; Pérez-López, L.A.; Rivas-Galindo, V.M.; Paniagua-Vega, D.; Galindo-Rodríguez, S.A.; Álvarez-Román, R. Simultaneous GC-FID quantification of main components of Rosmarinus officinalis L. and Lavandula dentata essential oils in polymeric nanocapsules for antioxidant application. J. Anal. Methods Chem. 2019. [CrossRef] [PubMed]

410. Oliveira, P.M.; Sampaio, T.R.; França, L.C.; Gratieri, T.; Cunha-Filho, M.; Gelfuso, G.M. LC-MS bioanalytical method for simultaneous determination of latanoprost and minoxidil in the skin. J. Pharm. Biomed. Anal. 2020, 187, 113373. [CrossRef]

411. Rata, D.M.; Cadinoiu, A.N.; Atanase, L.I.; Popa, M.; Mihai, C.-T.; Solcan, C.; Ochiuz, L.; Vochita, G. Topical formulations containing aptamer-functionalized nanocapsules loaded with 5-fluorouracil-An innovative concept for the skin cancer therapy. Mater. Sci. Eng. C 2021, 119, 111591. [CrossRef]

412. Ramezanli, T.; Kilfoyle, B.E.; Zhang, Z.; Michniak-Kohn, B.B. Polymeric nanospheres for topical delivery of vitamin D3. Int. J. Pharm. 2017, 516, 196-203. [CrossRef]

413. Donalisio, M.; Leone, F.; Civra, A.; Spagnolo, R.; Ozer, O.; Lembo, D.; Cavalli, R. Acyclovir-loaded chitosan nanospheres from nano-emulsion templating for the topical treatment of herpesviruses infections. Pharmaceutics 2018, 10, 46. [CrossRef]

414. Lucena, P.A.; Nascimento, T.L.; Gaeti, M.P.; de Ávila, R.I.; Mendes, L.P.; Vieira, M.S.; Fabrini, D.; Amaral, A.C.; Lima, E.M. In vivo vaginal fungal load reduction after treatment with itraconazole-loaded polycaprolactone-nanoparticles. J. Biomed. Nanotechnol. 2018, 14, 1347-1358. [CrossRef] [PubMed]

415. Badihi, A.; Frušić-Zlotkin, M.; Soroka, Y.; Benhamron, S.; Tzur, T.; Nassar, T.; Benita, S. Topical nano-encapsulated cyclosporine formulation for atopic dermatitis treatment. Nanomed. Nanotechnol. Biol. Med. 2020, 24, 102140. [CrossRef]

416. Mo, C.; Lu, L.; Liu, D.; Wei, K. Development of erianin-loaded dendritic mesoporous silica nanospheres with pro-apoptotic effects and enhanced topical delivery. J. Nano Biotechnol. 2020, 18, 1-14. [CrossRef]

417. Escalona-Rayo, O.; Fuentes-Vázquez, P.; Jardon-Xicotencatl, S.; García-Tovar, C.G.; Mendoza-Elvira, S.; Quintanar-Guerrero, D. Rapamycin-loaded polysorbate 80-coated PLGA nanoparticles: Optimization of formulation variables and in vitro anti-glioma assessment. J. Drug Deliv. Sci. Technol. 2019, 52, 488-499. [CrossRef]

418. Traeger, A.; Voelker, S.; Shkodra-Pula, B.; Kretzer, C.; Schubert, S.; Gottschaldt, M.; Schubert, U.S.; Werz, O. Improved Bioactivity of the Natural Product 5-Lipoxygenase Inhibitor Hyperforin by Encapsulation into Polymeric Nanoparticles. Mol. Pharm. 2020, 17, 810-816. [CrossRef] [PubMed]

419. Saqib, M.; Ali Bhatti, A.S.; Ahmad, N.M.; Ahmed, N.; Shahnaz, G.; Lebaz, N.; Elaissari, A. Amphotericin B Loaded Polymeric Nanoparticles for Treatment of Leishmania Infections. Nanomaterials 2020, 10, 1152. [CrossRef]

420. Günday, C.; Anand, S.; Gencer, H.B.; Munafò, S.; Moroni, L.; Fusco, A.; Donnarumma, G.; Ricci, C.; Hatir, P.C.; Türeli, N.G.; et al. Ciprofloxacin-loaded polymeric nanoparticles incorporated electrospun fibers for drug delivery in tissue engineering applications. Drug Deliv. Transl. Res. 2020, 10, 706-720. [CrossRef]

421. Gao, M.; Long, X.; Du, J.; Teng, M.; Zhang, W.; Wang, Y.; Wang, X.; Wang, Z.; Zhang, P.; Li, J. Enhanced curcumin solubility and antibacterial activity by encapsulation in PLGA oily core nanocapsules. Food Funct. 2020, 11, 448-455. [CrossRef] [PubMed]

422. Bechnak, L.; Khalil, C.; El Kurdi, R.; Khnayzer, R.S.; Patra, D. Curcumin encapsulated colloidal amphiphilic block co-polymeric nanocapsules: Colloidal nanocapsules enhance photodynamic and anticancer activities of curcumin. Photochem. Photobiol. Sci. 2020, 19, 1088-1098. [CrossRef] [PubMed]

423. Avramović, N.; Mandić, B.; Savić-Radojević, A.; Simić, T. Polymeric Nanocarriers of Drug Delivery Systems in Cancer Therapy. Pharmaceutics 2020, 12, 298. [CrossRef]

424. Jummes, B.; Sganzerla, W.G.; da Rosa, C.G.; Noronha, C.M.; Nunes, M.R.; Bertoldi, F.C.; Barreto, P.L.M. Antioxidant and

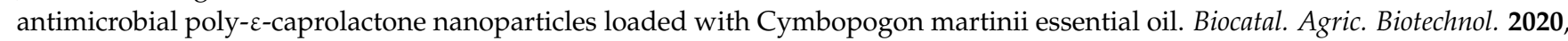
23, 101499. [CrossRef]

425. Pina-Barrera, A.M.; Álvarez-Román, R.; Báez-González, J.G.; Amaya-Guerra, C.A.; Rivas-Morales, C.; Gallardo-Rivera, C.T.; Galindo-Rodríguez, S.A. Application of a multisystem coating based on polymeric nanocapsules containing essential oil of Thymus vulgaris L. to increase the shelf life of table grapes (Vitis vinifera L.). IEEE Trans. Nanobiosci. 2019, 18, 549-557. [CrossRef] [PubMed]

426. Froiio, F.; Ginot, L.; Paolino, D.; Lebaz, N.; Bentaher, A.; Fessi, H.; Elaissari, A. Essential oils-loaded polymer particles: Preparation, characterization and antimicrobial property. Polymers 2019, 11, 1017. [CrossRef]

427. Ramezanli, T.; Zhang, Z.; Michniak-Kohn, B.B. Development and characterization of polymeric nanoparticle-based formulation of adapalene for topical acne therapy. Nanomedicine 2017, 13, 143-152. [CrossRef] [PubMed]

428. Sallam, M.A.; Marin Bosca, M.T. Mechanistic Analysis of Human Skin Distribution and Follicular Targeting of Adapalene-Loaded Biodegradable Nanospheres With an Insight Into Hydrogel Matrix Influence, In Vitro Skin Irritation, and In Vivo Tolerability. J. Pharm. Sci. 2017, 106, 3140-3149. [CrossRef]

429. Ro, J.; Kim, Y.; Kim, H.; Park, K.; Lee, K.-E.; Khadka, P.; Yun, G.; Park, J.; Chang, S.T.; Lee, J. Pectin micro-and nano-capsules of retinyl palmitate as cosmeceutical carriers for stabilized skin transport. Korean J. Physiol. Pharmacol. 2015, 19, 59-64. [CrossRef] [PubMed]

430. Malinovskaja-Gomez, K.; Labouta, H.; Schneider, M.; Hirvonen, J.; Laaksonen, T. Transdermal iontophoresis of flufenamic acid loaded PLGA nanoparticles. Eur. J. Pharm. Sci. 2016, 89, 154-162. [CrossRef] [PubMed] 
431. Chaudhri, S.; Jain, N. History of cosmetics. Asian J. Pharm. 2014, 3. [CrossRef]

432. Lohani, A.; Verma, A.; Joshi, H.; Yadav, N.; Karki, N. Nanotechnology-based cosmeceuticals. Int. Sch. Res. Not. 2014, $2014,14$. [CrossRef]

433. Lekki, J.; Stachura, Z.; Dabros, W.; Stachura, J.; Menzel, F.; Reinert, T.; Butz, T.; Pallon, J.; Gontier, E.; Ynsa, M.D.; et al. On the follicular pathway of percutaneous uptake of nanoparticles: Ion microscopy and autoradiography studies. Nucl. Instrum. Methods Phys. Res. Sect. B-Beam Interact. Mater. At. 2007, 260, 174-177. [CrossRef]

434. Menzel, F.; Reinert, T.; Vogt, J.; Butz, T. Investigations of percutaneous uptake of ultrafine $\mathrm{TiO}_{2}$ particles at the high energy ion nanoprobe LIPSION. Nucl. Instrum. Methods Phys. Res. Sect. B: Beam Interact. Mater. At. 2004, 219, 82-86. [CrossRef]

435. Magdassi, S. Delivery systems in cosmetics. Colloids Surf. A Physicochem. Eng. Asp. 1997, 123-124, 671-679. [CrossRef]

436. Vinetsky, Y.; Magdassi, S. Microcapsules in cosmetics. In Novel Cosmetic Delivery Systems; Marcel Dekker: New York, NY, USA, 1998; pp. 301-302.

437. Touitou, E. Novel Cosmetic Delivery Systems; CRC Press: Boca Raton, FL, USA, 1998.

438. Magdassi, S.; Touitou, E. Novel cosmetic delivery systems. In Cosmetic Science and Technology Series; Marcel Dekker: New York, NY, USA, 1999.

439. Magdassi, S.; Touitou, E. Cosmeceutics and delivery systems. In Novel Cosmetic Delivery Systems; CRC Press: Boca Raton, FL, USA, 1999; pp. 1-8.

440. Walters, K.A. Dermatological and Transdermal Formulations; CRC Press: Boca Raton, FL, USA, 2002; p. 592.

441. Badihi, A.; Debotton, N.; Frušić-Zlotkin, M.; Soroka, Y.; Neuman, R.; Benita, S. Enhanced cutaneous bioavailability of dehydroepiandrosterone mediated by nano-encapsulation. J. Control. Release 2014, 189, 65-71. [CrossRef] [PubMed]

442. Benita, S.; Tamilvanan, S. Lipid and polymeric colloidal carriers for ocular drug delivery. Drugs Pharm. Sci. 2006, $158,587$.

443. Touitou, E.; Barry, B.W. Enhancement in Drug Delivery; CRC Press: Boca Raton, FL, USA, 2006; p. 656.

444. Benita, S.; Martini, M.; Orecchioni, A.; Seiller, M. Cosmetic applications of colloidal delivery systems. Drugs Pharm. Sci. 2006, 158, 707.

445. Benita, S. Microencapsulation: Methods and Industrial Applications; CRC Press: Boca Raton, FL, USA, $2005 ;$ p. 781.

446. Wong, O.; Tsuzuki, N.; Nghiem, B.; Kuehnhoff, J.; Itoh, T.; Masaki, K.; Huntington, J.; Konishi, R.; Rytting, J.; Higuchi, T. Unsaturated cyclic ureas as new non-toxic biodegradable transdermal penetration enhancers. II. Evaluation study. Int. J. Pharm. 1989, 52, 191-202. [CrossRef]

447. Pham, Q.D.; Björklund, S.; Engblom, J.; Topgaard, D.; Sparr, E. Chemical penetration enhancers in stratum corneum-Relation between molecular effects and barrier function. J. Control. Release 2016, 232, 175-187. [CrossRef]

448. Üner, M.; Wissing, S.; Yener, G.; Müller, R. Skin moisturizing effect and skin penetration of ascorbyl palmitate entrapped in solid lipid nanoparticles (SLN) and nanostructured lipid carriers (NLC) incorporated into hydrogel. Die Pharm. -Int. J. Pharm. Sci. 2005, 60, 751-755.

449. Perugini, P.; Genta, I.; Pavanetto, F.; Conti, B.; Scalia, S.; Baruffini, A. Study on glycolic acid delivery by liposomes and microspheres. Int. J. Pharm. 2000, 196, 51-61. [CrossRef]

450. Bernardi, D.S.; Pereira, T.A.; Maciel, N.R.; Bortoloto, J.; Viera, G.S.; Oliveira, G.C.; Rocha-Filho, P.A. Formulation and stability of oil-in-water nanoemulsions containing rice bran oil: In vitro and in vivo assessments. J. Nanobiotechnol. 2011, 9, 44. [CrossRef]

451. Boonme, P. Uses of microemulsions as novel vehicles in skin care products. Househ. Pers. Care Today 2009, 3, 18-20.

452. Vorarat, S.; Managit, C.; Iamthanakul, L.; Soparat, W.; Kamkaen, N. Examination of antioxidant activity and development of rice bran oil and gamma-oryzanol microemulsion. J. Health Res. 2010, 24, 67-72.

453. Mahrhauser, D.; Nagelreiter, C.; Baierl, A.; Skipiol, J.; Valenta, C. Influence of a multiple emulsion, liposomes and a microemulsion gel on sebum, skin hydration and TEWL. Int. J. Cosmet. Sci. 2015, 37, 181-186. [CrossRef] [PubMed]

454. Linn, E.E.; Pohland, R.C.; Byrd, T.K. Microemulsion for intradermal delivery of cetyl alcohol and octyl dimethyl PABA. Drug Dev. Ind. Pharm. 1990, 16, 899-920. [CrossRef]

455. Mueller, R.H.; Petersen, R.D.; Hommoss, A.; Pardeike, J. Nanostructured lipid carriers (NLC) in cosmetic dermal products. Adv. Drug Deliv. Rev. 2007, 59, 522-530. [CrossRef]

456. Wissing, S.A.; Muller, R.H. The influence of solid lipid nanoparticles on skin hydration and viscoelasticity-In vivo study. Eur. J. Pharm. Biopharm. 2003, 56, 67-72. [CrossRef]

457. Choi, W.S.; Cho, H.I.; Lee, H.Y.; Lee, S.H.; Choi, Y.W. Enhanced occlusiveness of nanostructured lipid carrier (NLC)-based carbogel as a skin moisturizing vehicle. J. Pharm. Investig. 2010, 40, 373-378.

458. de Azevedo Ribeiro, R.C.; Barreto, S.M.A.G.; Ostrosky, E.A.; Rocha-Filho, P.A.; Verissimo, L.M.; Ferrari, M. Production and characterization of cosmetic nanoemulsions containing Opuntia ficus-indica (L.) mill extract as moisturizing agent. Molecules 2015, 20, 2492. [CrossRef]

459. Thakur, V.; Arora, S.; Prashar, B.; Vishal, P. Niosomes and liposomes-vesicular approach towards transdermal drug delivery. Int. J. Pharm. Chem. Sci. 2012, 1, 981-993.

460. Gupta, A.; Prajapati, S.K.; Balamurugan, M.; Singh, M.; Bhatia, D. Design and development of a proniosomal transdermal drug delivery system for captopril. Trop. J. Pharm. Res. 2007, 6, 687-693. [CrossRef]

461. Yamaguchi, Y.; Nagasawa, T.; Nakamura, N.; Takenaga, M.; Mizoguchi, M.; Kawai, S.-i.; Mizushima, Y.; Igarashi, R. Successful treatment of photo-damaged skin of nano-scale atRA particles using a novel transdermal delivery. J. Control. Release 2005, 104, 29-40. [CrossRef] 
462. Lehman, P.A.; Slattery, J.T.; Franz, T.J. Percutaneous Absorption of Retinoids: Influence of Vehicle, Light Exposure, and Dose. J. Investig. Dermatol. 1988, 91. [CrossRef]

463. Elbaum, D.J. Comparison of the stability of topical isotretinoin and topical tretinoin and their efficacy in acne. J. Am. Acad. Dermatol. 1988, 19, 486-491. [CrossRef]

464. Scientific Committee on Consumer Safety. Available online: https:/ / ec.europa.eu/health/scientific_committees/consumer_ safety/docs/sccs_o_199.pdf (accessed on 31 January 2021).

465. Ghosh, D.; Murthy, U. Antiaging benefits of a topical formulation containing coenzyme Q10: Results of 2 clinical studies. Cosmet. Dermatol. Cedar Knolls 2002, 15, 55-63.

466. El-Leithy, E.S.; Makky, A.M.; Khattab, A.M.; Hussein, D.G. Optimization of nutraceutical coenzyme Q10 nanoemulsion with improved skin permeability and anti-wrinkle efficiency. Drug Dev. Ind. Pharm. 2018, 44, 316-328. [CrossRef]

467. Eiras, F.; Amaral, M.H.; Silva, R.; Martins, E.; Lobo, J.M.S.; Silva, A.C. Characterization and biocompatibility evaluation of cutaneous formulations containing lipid nanoparticles. Int. J. Pharm. 2017, 519, 373-380. [CrossRef]

468. Draelos, Z.D.; Marenus, K.D. Cellulite: Etiology and purported treatment. Dermatol. Surg. 1997, 23, 1177. [CrossRef]

469. Rosenbaum, M.; Prieto, V.; Hellmer, J.; Boschmann, M.; Krueger, J.; Leibel, R.L.; Ship, A.G. An exploratory investigation of the morphology and biochemistry of cellulite. Plast. Reconstr. Surg. 1998, 101, 1934-1939. [CrossRef]

470. Piérard, G.E.; Nizet, J.-L.; Piérard-Franchimont, C. Cellulite: From standing fat herniation to hypodermal stretch marks. Am. J. Dermatopathol. 2000, 22, 34-37. [CrossRef]

471. Rossi, A.B.R.; Vergnanini, A.L. Cellulite: A review. J. Eur. Acad. Dermatol. Venereol. 2000, 14, 251-262. [CrossRef] [PubMed]

472. Hamilton, E.; Greenway, F.; Bray, G. Regional fat loss from the thigh in women using 2\% aminophylline. Obes. Res. 1993, 1 (Suppl 2), 95S.

473. Artz, J.S.; Dinner, M.I. Treatment of cellulite deformities of the thighs with topical aminophylline gel. Can. J. Plast. Surg. 1995, 3, 45-50. [CrossRef]

474. Herman, A.; Herman, A.P. Caffeine's Mechanisms of Action and Its Cosmetic Use. Ski. Pharmacol. Physiol. 2013, 26, 8-14. [CrossRef] [PubMed]

475. Touitou, E.; Levi-Schaffer, F.; Dayan, N.; Alhaique, F.; Riccieri, F. Modulation of caffeine skin delivery by carrier design: Liposomes versus permeation enhancers. Int. J. Pharm. 1994, 103, 131-136. [CrossRef]

476. Hamishehkar, H.; Shokri, J.; Fallahi, S.; Jahangiri, A.; Ghanbarzadeh, S.; Kouhsoltani, M. Histopathological evaluation of caffeine-loaded solid lipid nanoparticles in efficient treatment of cellulite. Drug Dev. Ind. Pharm. 2015, 41, 1640-1646. [CrossRef]

477. Gloster, H.M., Jr.; Brodland, D.G. The epidemiology of skin cancer. Dermatol. Surg. 1996, 22, 217-226. [CrossRef]

478. Matsumura, Y.; Ananthaswamy, H.N. Toxic effects of ultraviolet radiation on the skin. Toxicol. Appl. Pharmacol. 2004, 195, 298-308. [CrossRef] [PubMed]

479. Smijs, T.G.; Pavel, S. Titanium dioxide and zinc oxide nanoparticles in sunscreens: Focus on their safety and effectiveness. Nanotechnol. Sci. Appl. 2011, 4, 95. [CrossRef] [PubMed]

480. Giokas, D.L.; Salvador, A.; Chisvert, A. UV filters: From sunscreens to human body and the environment. Trac Trends Anal. Chem. 2007, 26, 360-374. [CrossRef]

481. Touitou, E.; Godin, B. Skin nonpenetrating sunscreens for cosmetic and pharmaceutical formulations. Clin. Dermatol. 2008, 26, 375-379. [CrossRef]

482. Badea, G.; Lăcătuşu, I.; Badea, N.; Ott, C.; Meghea, A. Use of various vegetable oils in designing photoprotective nanostructured formulations for UV protection and antioxidant activity. Ind. Crop. Prod. 2015, 67, 18-24. [CrossRef]

483. Tofani, R.P.; Sumirtapura, Y.C.; Darijanto, S.T. Formulation, Characterisation, and in Vitro Skin Diffusion of Nanostructured Lipid Carriers for Deoxyarbutin Compared to a Nanoemulsion and Conventional Cream. Sci. Pharm. 2016, 84, 634. [CrossRef]

484. Souza, C.; de Freitas, L.A.P.; Maia Campos, P.M.B.G. Topical Formulation Containing Beeswax-Based Nanoparticles Improved In Vivo Skin Barrier Function. AAPS PharmSciTech 2017, 18, 2505-2516. [CrossRef]

485. Ghanbarzadeh, S.; Hariri, R.; Kouhsoltani, M.; Shokri, J.; Javadzadeh, Y.; Hamishehkar, H. Enhanced stability and dermal delivery of hydroquinone using solid lipid nanoparticles. Colloids Surf. B Biointerfaces 2015, 136, 1004-1010. [CrossRef] [PubMed]

486. Shrotriya, S.; Ranpise, N.; Satpute, P.; Vidhate, B. Skin targeting of curcumin solid lipid nanoparticles-engrossed topical gel for the treatment of pigmentation and irritant contact dermatitis. Artif. Cells Nanomed. Biotechnol. 2018, 46, 1471-1482. [CrossRef] [PubMed]

487. Marto, J.; Sangalli, C.; Capra, P.; Perugini, P.; Ascenso, A.; Gonçalves, L.; Ribeiro, H. Development and characterization of new and scalable topical formulations containing N-acetyl-d-glucosamine-loaded solid lipid nanoparticles. Drug Dev. Ind. Pharm. 2017, 43, 1792-1800. [CrossRef]

488. Banna, H.; Hasan, N.; Lee, J.; Kim, J.; Cao, J.; Lee, E.H.; Moon, H.R.; Chung, H.Y.; Yoo, J.-W. In vitro and in vivo evaluation of MHY908-loaded nanostructured lipid carriers for the topical treatment of hyperpigmentation. J. Drug Deliv. Sci. Technol. 2018, 48, 457-465. [CrossRef]

489. Aliasgharlou, L.; Ghanbarzadeh, S.; Azimi, H.; Zarrintan, M.H.; Hamishehkar, H. Nanostructured lipid carrier for topical application of N-acetyl glucosamine. Adv. Pharm. Bull. 2016, 6, 581. [CrossRef]

490. Fachinetti, N.; Rigon, R.B.; Eloy, J.O.; Sato, M.R.; Dos Santos, K.C.; Chorilli, M. Comparative study of glyceryl behenate or polyoxyethylene 40 stearate-based lipid carriers for trans-resveratrol delivery: Development, characterization and evaluation of the in vitro tyrosinase inhibition. AAPS PharmSciTech 2018, 19, 1401-1409. [CrossRef] [PubMed] 
491. Khameneh, B.; Halimi, V.; Jaafari, M.R.; Golmohammadzadeh, S. Safranal-loaded solid lipid nanoparticles: Evaluation of sunscreen and moisturizing potential for topical applications. Iran. J. Basic Med. Sci. 2015, 18, 58.

492. Rodrigues, L.R.; Jose, J. Exploring the photo protective potential of solid lipid nanoparticle-based sunscreen cream containing Aloe vera. Environ. Sci. Pollut. Res. 2020, 27, 20876-20888. [CrossRef]

493. Aryani, R.; Hidayat, A.; Darma, G.; Utami, O. In Effect of solid lipid nanoparticles system on the stability of Green Tea leaves (Camellia sinensis L. Kuntze) extract as sunscreen. J. Phys. Conf. Ser. 2019, 1375, 012078. [CrossRef]

494. Andreani, T.; Dias-Ferreira, J.; Fangueiro, J.; Souza, A.; Kiill, C.; Gremião, M.; García, M.; Silva, A.; Souto, E. Formulating octyl methoxycinnamate in hybrid lipid-silica nanoparticles: An innovative approach for UV skin protection. Heliyon 2020, 6, e03831. [CrossRef]

495. Badea, G.; Badea, N.; Brasoveanu, L.I.; Mihaila, M.; Stan, R.; Istrati, D.; Balaci, T.; Lacatusu, I. Naringenin improves the sunscreen performance of vegetable nanocarriers. New J. Chem. 2017, 41, 480-492. [CrossRef]

496. Dario, M.F.; Oliveira, F.F.; Marins, D.S.S.; Baby, A.R.; Velasco, M.V.R.; Lobenberg, R.; Bou-Chacra, N.A. Synergistic photoprotective activity of nanocarrier containing oil of Acrocomia aculeata (Jacq.) Lodd. Ex. Martius-Arecaceae. Ind. Crop. Prod. 2018, 112, 305-312. [CrossRef]

497. Lacatusu, I.; Arsenie, L.V.; Badea, G.; Popa, O.; Oprea, O.; Badea, N. New cosmetic formulations with broad photoprotective and antioxidative activities designed by amaranth and pumpkin seed oils nanocarriers. Ind. Crop. Prod. 2018, 123, 424-433. [CrossRef]

498. Lee, X.Y.; Chu, C.C.; Hasan, Z.A.B.A.; Chua, S.K.; Nyam, K.L. Novel nanostructured lipid carriers with photoprotective properties made from carnauba wax, beeswax, and kenaf seed oil. J. Am. Oil Chem. Soc. 2019, 96, 201-211. [CrossRef]

499. Do Prado, A.H.; Araújo, V.H.S.; Eloy, J.O.; Fonseca-Santos, B.; Pereira-da-Silva, M.A.; Peccinini, R.G.; Chorilli, M. Synthesis and Characterization of Nanostructured Lipid Nanocarriers for Enhanced Sun Protection Factor of Octyl p-methoxycinnamate. AAPS PharmSciTech 2020, 21, 125. [CrossRef]

500. Daré, R.G.; Costa, A.; Nakamura, C.V.; Truiti, M.C.; Ximenes, V.F.; Lautenschlager, S.O.; Sarmento, B. Evaluation of Lipid Nanoparticles for Topical Delivery of Protocatechuic Acid and Ethyl Protocatechuate as a New Photoprotection Strategy. Int. J. Pharm. 2020, 582, 119336. [CrossRef] [PubMed]

501. Suter, F.; Schmid, D.; Wandrey, F.; Zülli, F. Heptapeptide-loaded solid lipid nanoparticles for cosmetic anti-aging applications. Eur. J. Pharm. Biopharm. 2016, 108, 304-309. [CrossRef]

502. Goindi, S.; Guleria, A.; Aggarwal, N. Development and evaluation of solid lipid nanoparticles of N-6-furfuryl adenine for prevention of photoaging. J. Biomed. Nanotechnol. 2015, 11, 1734-1746. [CrossRef]

503. Castellani, S.; Trapani, A.; Spagnoletta, A.; Di Toma, L.; Magrone, T.; Di Gioia, S.; Mandracchia, D.; Trapani, G.; Jirillo, E.; Conese, M. Nanoparticle delivery of grape seed-derived proanthocyanidins to airway epithelial cells dampens oxidative stress and inflammation. J. Transl. Med. 2018, 16, 1-15. [CrossRef] [PubMed]

504. Rocha, V.; Marques, C.; Figueiredo, J.; Gaio, A.; Costa, P.; Lobo, J.S.; Almeida, I. In vitro cytotoxicity evaluation of resveratrolloaded nanoparticles: Focus on the challenges of in vitro methodologies. Food Chem. Toxicol. 2017, 103, 214-222. [CrossRef] [PubMed]

505. Shoviantari, F.; Erawati, T.; Soeratri, W. Coenzyme Q10 nanostructured lipid carriers as an inducer of the skin fibroblast cell and its irritability test in a mice model. J. Basic Clin. Physiol. Pharmacol. 2019, 30, 20190320. [CrossRef] [PubMed]

506. Ammar, H.O.; Ghorab, M.M.; Mostafa, D.M.; Ibrahim, E.S. Folic acid loaded lipid nanocarriers with promoted skin antiaging and antioxidant efficacy. J. Drug Deliv. Sci. Technol. 2016, 31, 72-82. [CrossRef]

507. Durán, N.; Costa, A.F.; Stanisic, D.; Bernardes, J.S.; Tasic, L. Nanotoxicity and Dermal Application of Nanostructured Lipid Carrier Loaded with Hesperidin from Orange Residue. J. Phys. Conf. Ser. 2019, 1323, 12021. [CrossRef]

508. Ijaz, M.; Akhtar, N. Fatty acids based $\alpha$-Tocopherol loaded nanostructured lipid carrier gel: In vitro and in vivo evaluation for moisturizing and anti-aging effects. J. Cosmet. Derm. 2020. [CrossRef]

509. Kumar, P.; Singh, A. Nanostructured lipid carriers (NLCS): A prominent topical delivery system for coenzyme Q10 and myrica esculenta leaves extract for anti-aging potential. Int. J. Pharm. Pharm. Sci. 2018, 10, 106-112.

510. Barua, S.; Kim, H.; Hong, S.-C.; Yoo, S.-Y.; Shin, D.; Lee, C.-L.; Na, S.-J.; Kim, Y.H.; Jo, K.; Yun, G. Moisturizing effect of serine-loaded solid lipid nanoparticles and polysaccharide-rich extract of root Phragmites communis incorporated in hydrogel bases. Arch. Pharmacal. Res. 2017, 40, 250-257. [CrossRef]

511. Reeta, A.C.; Newton, A.M.J. Synthesis and Characterization of Valacyclovir HCl Hybrid Solid Lipid Nanoparticles by Using Natural Oils. Recent Pat. Drug. Deliv. Formul. 2019, 13, 46-61.

512. Wolf, J.R.; Heckler, C.E.; Guido, J.J.; Peoples, A.R.; Gewandter, J.S.; Ling, M.; Vinciguerra, V.P.; Anderson, T.; Evans, L.; Wade, J. Oral curcumin for radiation dermatitis: A URCC NCORP study of 686 breast cancer patients. Supportive Care Cancer 2018, 26, 1543-1552. [CrossRef]

513. Hallan, S.S.; Sguizzato, M.; Pavoni, G.; Baldisserotto, A.; Drechsler, M.; Mariani, P.; Esposito, E.; Cortesi, R. Ellagic acid containing nanostructured lipid carriers for topical application: A preliminary study. Molecules 2020, 25, 1449. [CrossRef]

514. Helal, D.A.; Teaima, M.H.; Abd El-Rhman, D.; Abdel-Halim, S.A.; El-Nabaraw, M. Preparation and evaluation of niosomes containing an anticellulite drug. Inventi Impact Pharm. Tech. 2015, 2, 95-101.

515. Burchacka, E.; Potaczek, P.; Paduszyński, P.; Karłowicz-Bodalska, K.; Han, T.; Han, S. New effective azelaic acid liposomal gel formulation of enhanced pharmaceutical bioavailability. Biomed. Pharmacother. 2016, 83, 771-775. [CrossRef] 
516. Budhiraja, A.; Dhingra, G. Development and characterization of a novel antiacne niosomal gel of rosmarinic acid. Drug Deliv. 2015, 22, 723-730. [CrossRef] [PubMed]

517. Vasily, D.B. Topical Treatment with Liposomal Sodium Copper Chlorophyllin Complex in Subjects With Facial Redness and Erythematotelangiectatic Rosacea: Case Studies. J. Drugs Dermatol. 2015, 14, 1157. [PubMed]

518. Galanakis, C.M. Phenols recovered from olive mill wastewater as additives in meat products. Trends Food Sci. Technol. 2018, 79, 98-105. [CrossRef]

519. Pires, F.; Geraldo, V.P.; Antunes, A.; Marletta, A.; Oliveira, O.N., Jr.; Raposo, M. On the role of epigallocatechin-3-gallate in protecting phospholipid molecules against UV irradiation. Colloids Surf. B Biointerfaces 2019, 173, 312-319. [CrossRef] [PubMed]

520. Zhang, Y.; Shen, L.; Zhang, K.; Guo, T.; Zhao, J.; Li, N.; Feng, N. Enhanced antioxidation via encapsulation of isooctyl pmethoxycinnamate with sodium deoxycholate-mediated liposome endocytosis. Int. J. Pharm. 2015, 496, 392-400. [CrossRef]

521. Zhang, W.; Yang, Y.; Lv, T.; Fan, Z.; Xu, Y.; Yin, J.; Liao, B.; Ying, H.; Ravichandran, N.; Du, Q. Sucrose esters improve the colloidal stability of nanoethosomal suspensions of (-)-epigallocatechin gallate for enhancing the effectiveness against UVB-induced skin damage. J. Biomed. Mater. Res. Part B Appl. Biomater. 2017, 105, 2416-2425. [CrossRef] [PubMed]

522. Cerqueira, C.; Nigro, F.; Campos, V.E.; Rossi, A.; Santos-Oliveira, R.; Cardoso, V.; Vermelho, A.B.; Dos Santos, E.P.; Mansur, C.R.E. Nanovesicle-based formulations for photoprotection: A safety and efficacy approach. Nanotechnology 2019, 30, 345102. [CrossRef]

523. Gollavilli, H.; Hegde, A.R.; Managuli, R.S.; Bhaskar, K.V.; Dengale, S.; Reddy, M.S.; Kalthur, G.; Mutalik, S. Naringin nanoethosomal novel sunscreen creams: Development and performance evaluation. Colloids Surf. B Biointerfaces 2020, $193,111122$. [CrossRef]

524. Avadhani, K.S.; Manikkath, J.; Tiwari, M.; Chandrasekhar, M.; Godavarthi, A.; Vidya, S.M.; Hariharapura, R.C.; Kalthur, G.; Udupa, N.; Mutalik, S. Skin delivery of epigallocatechin-3-gallate (EGCG) and hyaluronic acid loaded nano-transfersomes for antioxidant and anti-aging effects in UV radiation induced skin damage. Drug Deliv. 2017, 24, 61-74. [CrossRef] [PubMed]

525. Kwon, S.S.; Kim, S.Y.; Kong, B.J.; Kim, K.J.; Noh, G.Y.; Im, N.R.; Lim, J.W.; Ha, J.H.; Kim, J.; Park, S.N. Cell penetrating peptide conjugated liposomes as transdermal delivery system of Polygonum aviculare L. extract. Int. J. Pharm. 2015, 483, 26-37. [CrossRef] [PubMed]

526. Yadav, N.; Nanda, S.; Sharma, G.; Katare, O. Systematically optimized coenzyme q10-loaded novel proniosomal formulation for treatment of photo-induced aging in mice: Characterization, biocompatibility studies, biochemical estimations and anti-aging evaluation. J. Drug Target. 2016, 24, 257-271. [CrossRef]

527. Chaikul, P.; Khat-Udomkiri, N.; Iangthanarat, K.; Manosroi, J.; Manosroi, A. Characteristics and in vitro anti-skin aging activity of gallic acid loaded in cationic CTAB niosome. Eur. J. Pharm. Sci. 2019, 131, 39-49. [CrossRef]

528. Heydari, S.; Ghanbarzadeh, S.; Anoush, B.; Ranjkesh, M.; Javadzadeh, Y.; Kouhsoltani, M.; Hamishehkar, H. Nanoethosomal formulation of gammaoryzanol for skin-aging protection and wrinkle improvement: A histopathological study. Drug Dev. Ind. Pharm. 2017, 43, 1154-1162. [CrossRef] [PubMed]

529. Aboul-Einien, M.H.; Kandil, S.M.; Abdou, E.M.; Diab, H.M.; Zaki, M.S. Ascorbic acid derivative-loaded modified aspasomes: Formulation, in vitro, ex vivo and clinical evaluation for melasma treatment. J. Liposome Res. 2020, 30, 54-67. [CrossRef] [PubMed]

530. Yücel, Ç.; Şeker Karatoprak, G.; Değim, İ.T. Anti-aging formulation of rosmarinic acid-loaded ethosomes and liposomes. J. Microencapsul. 2019, 36, 180-191. [CrossRef]

531. Bi, Y.; Xia, H.; Li, L.; Lee, R.J.; Xie, J.; Liu, Z.; Qiu, Z.; Teng, L. Liposomal Vitamin D3 as an Anti-aging Agent for the Skin. Pharmaceutics 2019, 11,311. [CrossRef]

532. Mohammad, E. Anti-aging Effect of Free Curcumin and Niosome Entrapping Curcumin in $\mathrm{H}_{2} \mathrm{O}_{2}$-induced Aging in Human Fibroblast Cell Lines. J. Adv. Phys. 2019, 16, 237-246. [CrossRef]

533. Ruksiriwanich, W.; Jantrawut, P. In Transdermal Delivery Enhancement of Gel Containing Niosomes Loaded with Volvariella Volvacea Extract. Open Conf. Proc. J. 2015, 6, 10-17. [CrossRef]

534. Surini, S.; Djajadisastra, J. Formulation and in vitro Penetration Study of Transfersomes Gel Containing Gotu Kola Leaves Extract (Centella asiatica L. Urban). J. Young Pharm. 2018, 10, 27. [CrossRef]

535. Manca, M.L.; Matricardi, P.; Cencetti, C.; Peris, J.E.; Melis, V.; Carbone, C.; Escribano, E.; Zaru, M.; Fadda, A.M.; Manconi, M. Combination of argan oil and phospholipids for the development of an effective liposome-like formulation able to improve skin hydration and allantoin dermal delivery. Int. J. Pharm. 2016, 505, 204-211. [CrossRef]

536. Caddeo, C.; Manca, M.L.; Peris, J.E.; Usach, I.; Diez-Sales, O.; Matos, M.; Fernandez-Busquets, X.; Fadda, A.M.; Manconi, M. Tocopherol-loaded transfersomes: In vitro antioxidant activity and efficacy in skin regeneration. Int. J. Pharm. 2018, 551, 34-41. [CrossRef] [PubMed]

537. Candido, T.M.; Areias De Oliveira, C.; Ariede, M.B.; Velasco, M.V.R.; Rosado, C.; Baby, A.R. Safety and Antioxidant Efficacy Profiles of Rutin-Loaded Ethosomes for Topical Application. AAPS PharmSciTech 2018, 19, 1773-1780. [CrossRef]

538. Manca, M.L.; Firoznezhad, M.; Caddeo, C.; Marongiu, F.; Escribano-Ferrer, E.; Sarais, G.; Peris, J.E.; Usach, I.; Zaru, M.; Manconi, M.; et al. Phytocomplexes extracted from grape seeds and stalks delivered in phospholipid vesicles tailored for the treatment of skin damages. Ind. Crop. Prod. 2019, 128, 471-478. [CrossRef]

539. Ikawati, Z.; Murwanti, R.; Meliana, Y.; Kartika, W. The effect of nanoencapsulated centella asiatica L and zingiber officinale rosc. var. rubrrum combination to promotecollagen synthesis and decrease the diameter of adipocyte cells in female wistar rats. Int. J. Pharm. Sci. Res. 2016, 7, 1909. 
540. Freire, T.B.; Dario, M.F.; Mendes, O.G.; de Oliveira, A.C.; Vetore Neto, A.; de Faria, D.L.A.; Baby, A.R.; Velasco, M.V.R. Nanoemulsion containing caffeine for cellulite treatment: Characterization and in vitro evaluation. Braz. J. Pharm. Sci. 2019, 55, e18236/1-e18236/11. [CrossRef]

541. Taleb, M.H.; Abdeltawab, N.F.; Shamma, R.N.; Abdelgayed, S.S.; Mohamed, S.S.; Farag, M.A.; Ramadan, M.A. Origanum vulgare L. essential oil as a potential anti-acne topical nanoemulsion-In vitro and in vivo study. Molecules 2018, 23, 2164. [CrossRef]

542. Baccarin, T.; Mitjans, M.; Ramos, D.; Lemos-Senna, E.; Vinardell, M.P. Photoprotection by Punica granatum seed oil nanoemulsion entrapping polyphenol-rich ethyl acetate fraction against UVB-induced DNA damage in human keratinocyte (HaCaT) cell line. J. Photochem. Photobiol. B Biol. 2015, 153, 127-136. [CrossRef]

543. Cerqueira-Coutinho, C.; Santos-Oliveira, R.; dos Santos, E.; Mansur, C.R. Development of a photoprotective and antioxidant nanoemulsion containing chitosan as an agent for improving skin retention. Eng. Life Sci. 2015, 15, 593-604. [CrossRef]

544. Arianto, A.; Cindy, C. Preparation and Evaluation of Sunflower Oil Nanoemulsion As a Sunscreen. Open Access Maced. J. Med Sci. 2019, 7, 3757. [CrossRef] [PubMed]

545. Arianto, A.; Lie, D.Y.L.; Bangun, H.B. Preparation and Evaluation of Nanoemulgels Containing a Combination of Grape Seed Oil and Anisotriazine as Sunscreen. Open Access Maced. J. Med. Sci. 2020, 8, 994-999. [CrossRef]

546. Muhtadi, M.; Suhendi, A.; Wikantyasning, E.R. Gel nanoemulsion of rambutan (Nephelium lappaceum L.) fruit peel extracts: Formulation, physical properties, sunscreen protecting, and antioxidant activity. Asian J. Pharm. Clin. Res. 2017, 10, 220-224. [CrossRef]

547. Brownlow, B.; Nagaraj, V.J.; Nayel, A.; Joshi, M.; Elbayoumi, T. Development and in vitro evaluation of vitamin E-enriched nanoemulsion vehicles loaded with genistein for chemoprevention against UVB-induced skin damage. J. Pharm. Sci. 2015, 104, 3510-3523. [CrossRef] [PubMed]

548. da Cruz Gonçalves, M.; dos Santos, V.M.R.; Taylor, J.G.; Perasoli, F.B.; dos Santos, O.D.H.; Rabelo, A.C.S.; Rossoni Junior, J.V.; Costa, D.C.; Cazati, T. Preparation and characterization of a quercetin-tetraethyl ether-based photoprotective nanoemulsion. Química Nova 2019, 42, 365-370. [CrossRef]

549. Kajbafvala, A.; Salabat, A.; Salimi, A. Formulation, characterization, and in vitro/ex vivo evaluation of quercetin-loaded microemulsion for topical application. Pharm. Dev. Technol. 2018, 23, 741-750. [CrossRef]

550. Volpe, V.; Nascimento, D.S.; Insausti, M.; Grünhut, M. Octyl p-methoxycinnamate loaded microemulsion based on Ocimum basilicum essential oil. Characterization and analytical studies for potential cosmetic applications. Colloids Surf. A Physicochem. Eng. Asp. 2018, 546, 285-292. [CrossRef]

551. Azhar, S.N.A.S.; Ashari, S.E.; Salim, N. Development of a kojic monooleate-enriched oil-in-water nanoemulsion as a potential carrier for hyperpigmentation treatment. Int. J. Nanomed. 2018, 13, 6465. [CrossRef]

552. Jacobus Berlitz, S.; De Villa, D.; Maschmann Inácio, L.A.; Davies, S.; Zatta, K.C.; Guterres, S.S.; Külkamp-Guerreiro, I.C. Azelaic acid-loaded nanoemulsion with hyaluronic acid-a new strategy to treat hyperpigmentary skin disorders. Drug Dev. Ind. Pharm. 2019, 45, 642-650. [CrossRef]

553. Leny, K.; Harahap, U. Comparison of vitamin C (magnesium ascorbyl phosphate) formulation in nanoemulsion spray and cream as anti-aging. Int. J. Pharmtech. Res. 2016, 9, 399-407.

554. Ting, Y.; Hu, Y.T.; Hu, J.Y.; Chang, W.C.; Huang, Q.; Hsieh, S.C. Nanoemulsified adlay bran oil reduces tyrosinase activity and melanin synthesis in B16F10 cells and zebrafish. Food Sci. Nutr. 2019, 7, 3216-3223. [CrossRef]

555. Prabhu, D.; Ravikumar, P. Microencapsulation: A strategy to surpass photo instability and low penetrability of skin lightening agents. Int. J. Pharm. Sci. Res. 2020, 11, 3433-3441.

556. Yang, J.; Xu, H.; Wu, S.; Ju, B.; Zhu, D.; Yan, Y.; Wang, M.; Hu, J. Preparation and evaluation of microemulsion based transdermal delivery of Cistanche tubulosa phenylethanoid glycosides. Mol. Med. Rep. 2017, 15, 1109-1116. [CrossRef] [PubMed]

557. Puri, A.; Kaur, A.; Raza, K.; Goindi, S.; Katare, O.P. Development and evaluation of topical microemulsion of dibenzoylmethane for treatment of UV induced photoaging. J. Drug Deliv. Sci. Technol. 2017, 37, 1-12. [CrossRef]

558. Sainorudin, M.H.; Rozaini, M.Z.H.; Hamzah, H.; Saupi, A.A.M.; Norazemi, N.F.; Ismail, Z.; Ying, J.S.P.; Ibrahim, N.H.; Zain, M.H. Preliminary study of sunscreen and anti-tyrosinase effect on microemulsion extract from Melaleuca cajuputi essential oil using nonionic surfactant. GSTF J. Chem. Sci. 2015, 2, 1-9.

559. Priani, S.E.; Mela, K.A.; Lukmayani, Y. Development sunscreen microemulsion gel containing n-hexane fraction of mangosteen pericarp (Garcinia mangostana Linn.). Res. J. Pharm. Biol. Chem. Sci. 2017, 8, 229-235.

560. Sumaiyah; Leisyah, B.M. The effect of antioxidant of grapeseed oil as skin anti-aging in nanoemulsion and emulsion preparations. Rasayan J. Chem. 2019, 12, 1185-1194. [CrossRef]

561. Samson, S.; Basri, M.; Fard Masoumi, H.R.; Abdul Malek, E.; Abedi Karjiban, R. An artificial neural network based analysis of factors controlling particle size in a virgin coconut oil-based nanoemulsion system containing copper peptide. PLoS ONE 2016, 11, e0157737. [CrossRef]

562. Chaiyana, W.; Leelapornpisid, P.; Jakmunee, J.; Korsamphan, C. Antioxidant and moisturizing effect of Camellia assamica seed oil and its development into microemulsion. Cosmetics 2018, 5, 40. [CrossRef]

563. Nazliniwaty; Suryanto; Damanik, D.D. The utilization of Binahong (Anredera Cordifolia (ten.) Steenis) leaf as an anti aging. Asian J. Pharm. Clin. Res. 2018, 11, 1-3. 
564. Barreto, S.M.A.G.; Maia, M.S.; Benicá, A.M.; de Assis, H.R.B.S.; Leite-Silva, V.R.; da Rocha-Filho, P.A.; de Negreiros, M.M.F.; de Oliveira Rocha, H.A.; Ostrosky, E.A.; Lopes, P.S. Evaluation of in vitro and in vivo safety of the by-product of Agave sisalana as a new cosmetic raw material: Development and clinical evaluation of a nanoemulsion to improve skin moisturizing. Ind. Crop. Prod. 2017, 108, 470-479. [CrossRef]

565. Pereira, T.A.; Guerreiro, C.M.; Maruno, M.; Ferrari, M.; Rocha-Filho, P.A. Exotic vegetable oils for cosmetic o/w nanoemulsions: In vivo evaluation. Molecules 2016, 21, 248. [CrossRef] [PubMed]

566. Barradas, T.N.; de Campos, V.E.B.; Senna, J.P.; dos Santos Cerqueira Coutinho, C.; Tebaldi, B.S.; de Holanda e Silva, K.G.; Mansur, C.R.E. Development and characterization of promising $\mathrm{o} / \mathrm{w}$ nanoemulsions containing sweet fennel essential oil and non-ionic sufactants. Colloids Surf. A Physicochem. Eng. Asp. 2015, 480, 214-221. [CrossRef]

567. Balestrin, L.A.; Bidone, J.; Bortolin, R.C.; Moresco, K.; Moreira, J.C.; Teixeira, H.F. Protective effect of a hydrogel containing Achyrocline satureioides extract-loaded nanoemulsion against UV-induced skin damage. J. Photochem. Photobiol. B 2016, 163, 269-276. [CrossRef]

568. Sinha, P.; Srivastava, S.; Mishra, N.; Singh, D.K.; Luqman, S.; Chanda, D.; Yadav, N.P. Development, optimization, and characterization of a novel tea tree oil nanogel using response surface methodology. Drug Dev. Ind. Pharm. 2016, 42, 1434-1445. [CrossRef] [PubMed]

569. Contri, R.V.; Kulkamp-Guerreiro, I.C.; da Silva, S.J.; Frank, L.A.; Pohlmann, A.R.; Guterres, S.S. Nanoencapsulation of Rose-Hip Oil Prevents Oil Oxidation and Allows Obtainment of Gel and Film Topical Formulations. AAPS PharmSciTech 2016, 17, 863-871. [CrossRef] [PubMed]

570. Barbosa, T.C.; Nascimento, L.E.D.; Bani, C.; Almeida, T.; Nery, M.; Santos, R.S.; Renyelle de Oliveira Menezes, L.; Zielinska, A.; Fernandes, A.R.; Cardoso, J.C.; et al. Development, cytotoxicity and eye irritation profile of a new sunscreen formulation based on benzophenone-3-poly( $\varepsilon$-caprolactone) nanocapsules. Toxics 2019, 7, 51. [CrossRef] [PubMed]

571. Niu, X.; Wang, Z.; Zhang, L.; Quan, Y.; Wei, K. Experimental study of the protective effect of mesosilica-supported 5hydroxymethylfurfural on UV-induced aging of human dermal fibroblasts. RSC Adv. 2018, 8, 25021-25030. [CrossRef]

572. Eke, G.; Goni-de-Cerio, F.; Suarez-Merino, B.; Hasirci, N.; Hasirci, V. Biocompatibility of Dead Sea Water and retinyl palmitate carrying poly(3-hydroxybutyrateco-3-hydroxyvalerate) micro/nanoparticles designed for transdermal skin therapy. J. Bioact. Compat. Polym. 2015, 30, 455-471. [CrossRef]

573. Acosta, N.; Sanchez, E.; Calderon, L.; Cordoba-Diaz, M.; Cordoba-Diaz, D.; Dom, S.; Heras, A. Physical stability studies of semi-solid formulations from natural compounds loaded with chitosan microspheres. Mar. Drugs 2015, 13, 5901-5919. [CrossRef]

574. Hariyadi, D.M.; Rosita, N.; Rahayu, A. Design, optimization and characterization of glutathione loadedalginate microspheres for topical antiaging. J. Pharm. Pharmacogn. Res. 2019, 7, 223-233.

575. Zhang, H.; Liu, X.; Fu, S.; Chen, Y. Fabrication of light-colored lignin microspheres for developing natural sunscreens with favorable UV absorbability and staining resistance. Ind. Eng. Chem. Res. 2019, 58, 13858-13867. [CrossRef]

576. Monti, D.; Chetoni, P.; Burgalassi, S.; Tampucci, S.; Centini, M.; Anselmi, C. 4-Methylbenzylidene camphor microspheres: Reconstituted epidermis (Skinethic ${ }^{\circledR}$ ) permeation and distribution. Int. J. Cosmet. Sci. 2015, 37, 298-305. [CrossRef] [PubMed]

577. Zhao, X.-L.; Wang, D.; Gong, X.-F.; Sun, S.-P.; Li, Q. Preparation and characterization of microcapsules encapsulating octyl methoxycinnamate by complex coacervation. Indian J. Pharm. Sci. 2016, 78, 193-202. [CrossRef]

578. Wu, Y.; Qian, Y.; Lou, H.; Yang, D.; Qiu, X. Enhancing the Broad-Spectrum Adsorption of Lignin through Methoxyl Activation, Grafting Modification, and Reverse Self-Assembly. ACS Sustain. Chem. Eng. 2019, 7, 15966-15973. [CrossRef] 